Life Sciences Contributions

Royal Ontario. Museum

124

The Vegetation and Phytogeography of Coastal Southwestern James Bay

J.L. Riley

S.M. McKay

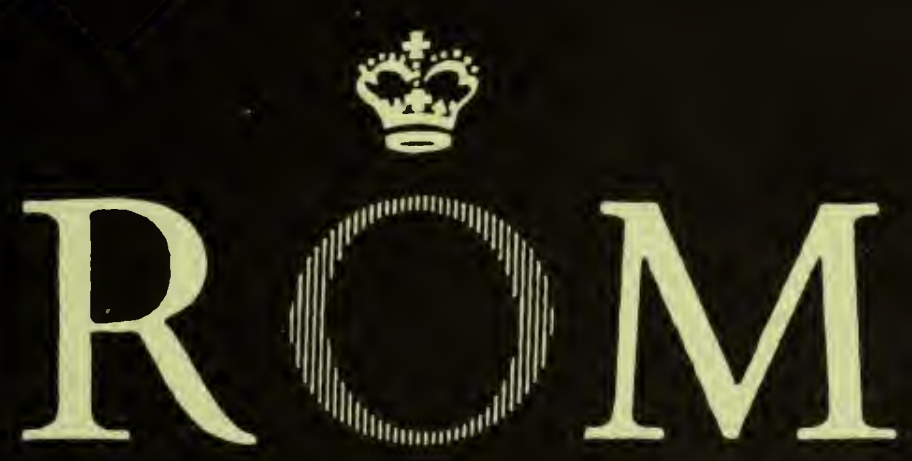




\section{ROYAL ONTARIO MUSEUM LIFE SCIENCES PUBLICATIONS INSTRUCTIONS TO AUTHORS}

Authors are to prepare their manuscripts carefully according to the following instructions. Failure to do so will result in the manuscript's being returned to the author for revision. All manuscripts are considered on the understanding that if accepted they will not be offered for publication elsewhere.

1. GENERAL Papers for publication are accepted from ROM staff members, Research Associates, or from researchers reporting on work done with ROM collections. In exceptional cases,monographic works on the flora and/or fauna of Ontario will be considered for publication by authors not affiliated with the ROM. Authors are expected to write clearly and concisely, and to omit all material not essential for an understanding of the main theme of the paper.

2. FORMAT Manuscripts are to be typed double-spaced (including captions, synonomies, literature cited, and tables) on 11 " $\times 81 / 2$ " paper with a $1 \frac{11 / 2}{}$ " margin on all sides. Three xerox copies are to be submitted to the Chairman of the Editorial Board, and the original retained by the author(s). A separate sheet is to be submitted giving author(s) names, affiliation, title of publication, series in which it is to appear, number of typed pages, number of tables, and number of figures. Manuscripts should normally be organized in the following order: Table of Contents, Abstract, Introduction, Materials and Methods, Results, Discussion, Conclusions, Summary (if paper is long), Acknowledgements, Literature Cited, and Appendices. Authors are encouraged to include foreign language translations of the Summary where appropriate. Headings of sections are to be left-justified to the text margin. The first line of the first paragraph in each new section should not be indented. Text-figures are referred to as "Fig. 1". Literature cited in the text is in the form "Jones (1972)" or "(Jones, 1972)" or "(Smith, 1960:71-79, fig. 17)".

3. STANDARD SOURCES The primary source for decisions on format and style is A Guide for Contributors and Editors of ROM Life Sciences Publications, available from the Chairman of the Editorial Board. Otherwise, consult CBE (AIBS) Style Manual (3rd Edition). Other standard sources are as follows: for English spelling (Concise Oxford Dictionary), for Canadian place names and coordinates (Gazetteer of Canada), and for spelling of geographic names (Times [London] Atlas).

4. ABSTRACT All papers are preceded by a short and factual abstract, about 3 per cent as long as the text, but not longer than 400 words. The abstract is to be followed by four to six keywords enclosed in brackets.

5. TAXONOMY The name of a taxon is given in full in headings, where it appears for the first time, or when the name begins a paragraph. Use authority and date if appropriate, with first mention of each taxon and not thereafter. Taxonomic papers follow the layout in Life Sciences Contribution 99, particularly the synonomies.

6. LITERATURE CITED References in the text cite author and date and are enclosed in parentheses (Smith, 1978). Complete references are listed in alphabetical order by author at the end of the paper. When there are two or more citations for an author, the works are listed chronologically. Names of joumals are not abbreviated. Consult Life Sciences Contributions beginning with 117 for correct bibliographic form.

7. TABLES All tables are numbered consecutively in arabic numerals in numerical order of their first mention in the text. Mark the appropriate text location of each table with a marginal notation. Each table is typed on a separate sheet. Avoid footnotes etc., to tables by building them into the title.

8. FIGURES All figures are numbered consecutively in arabic numerals. Component photographs or drawings are labelled sequentially in upper case letters. Mark the appropriate text location of each figure with a marginal notation. The intended reduction for figures is ideally one and a half to two times. All labelling on figures is in blue pencil and not inked or letraset. Halftones must be photographic prints of high contrast on glossy paper. Authors are to submit $10 " \times 8$ " copies with the MS and retain originals until they are requested. Figure captions are to appear grouped together on a separate page at the end of the MS. 
LIFE SCIENCES CONTRIBUTIONS

ROYAL ONTARIO MUSEUM

NUMBER 124

J.L. RILEY The Vegetation and Phytogeography
S.M. McKAY of Coastal Southwestern James Bay 


\section{ROYAL ONTARIO MUSEUM PUBLICATIONS IN LIFE SCIENCES}

The Royal Ontario Museum publishes three series in the Life Sciences:

LIFE SCIENCES CONTRIBUTIONS, a numbered series of original scientific publications including monographic works.

LIFE SCIENCES OCCASIONAL PAPERS, a numbered series of original scientific publications, primarily short and usually of taxonomic significance.

LIFE SCIENCES MISCELLANEOUS PUBLICATIONS, an unnumbered series of publications of varied subject matter and format

All manuscripts considered for publication are subject to the scrutiny and editorial policies of the Life Sciences Editorial Board, and to review by persons outside the Museum staff who are authorities in the particular field involved.

LIFE SCIENCES EDITORIAL BOARD

Senior Editor: R. D. JAMES

Editor: C. MCGOWAN

Editor: P. H. voN BITTER

J.L. RILEY is a Curatorial Assistant in the Department of Botany, Royal Ontario Museum and the Vascular Plant Herbarium, University of Toronto.

S.M. McKAY is a Curatorial Assistant in the Vascular Plant Herbarium, Department of Botany, University of Toronto.

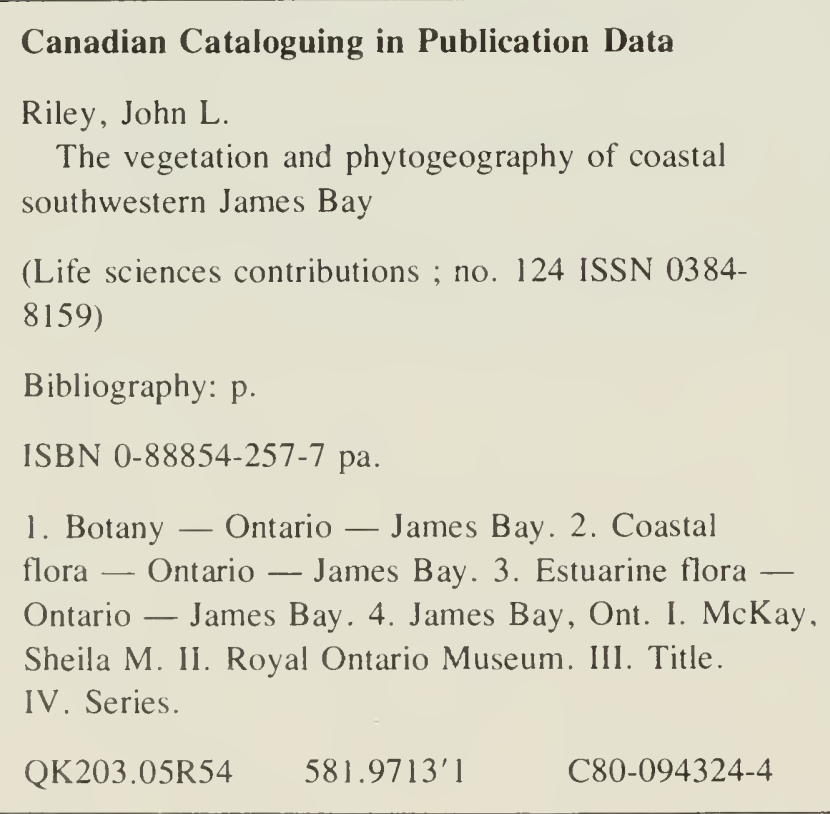

Publication date: 23 May 1980

ISBN: 0-88854-257-7

ISSN: 0384-8159

(C) The Royal Ontario Museum, 1980

100 Queen's Park, Toronto, Canada M5S 2C6

PRINTED AND BOUND IN CANADA AT THE ALGER PRESS 


\section{Contents}

Abstract 1

Introduction 1

Materials and Methods 3

Major Vascular Plant Associations 4

Coastal Communities 5

Estuarine Communities 11

Floristic Analysis 16

Affinities and Disjunctions 16

Discussion 23

Acknowledgements 27

Literature Cited 27

Vascular Plant Checklist 60 



\title{
The Vegetation and Phytogeography of Coastal Southwestern James Bay
}

\begin{abstract}
The southwestern James Bay region of the Hudson Bay Lowland, exemplified in study areas at Longridge, Puskwuche, and North Points, Shipsands Island and Arnold Point, and the Kinoje Lakes, supports a wide variety of coastal, estuarine, and interior wetland habitats. Their major associational series document a general homogeneity of zonation at coastal sites, and a strong dissimilarity between coastal-estuarine sites and the interior wetlands.

The major physiognomic formations at coastal-estuarine sites support various vegetation dominance types which are described and accompanied by a checklist of individual formations. Nearly 400 species of vascular plants are found in the study areas.

The floristic patterns apparent within the study areas are considered, as are the implications of 31 significantly disjunct plant species in terms of their postglacial migration into the region. Ongoing modes of species dispersal, as well as the possible migration of species through proglacial lake systems from the south, east, and west, and the possible circumdispersal around the Quebec-Labrador peninsula by east coast species, are all considered as processes contributing to the present status of these coincident lowland disjuncts.

Maps of the northeastern North American distributions of $62^{\circ}$ vascular plant species are included.
\end{abstract}

(Southwestern James Bay; Hudson Bay Lowland; vascular plant communities; checklists; disjunct distributions; plant geography)

\section{Introduction}

The Hudson Bay Lowland, in which the study areas are located (Fig. 1), is a geologic structural province defined by the extent of its paleozoic bedrock (Sanford et al., $1968)$, and also generally by the $150 \mathrm{~m}$ (500 ft.) elevation contour. It is a flat sedimentary basin close to the radiative centre of the Laurentide ice sheet, subsequently submerged by the late-glacial Tyrrell Sea (after about 8000 y B.P.), and currently undergoing rapid isostatic rebound. This process creates new coastal 
habitats which are continually evolving towards shallow interior peatlands. The Lowland extends from boreal forest in the south to maritime arctic tundra in the north; from seasonal frost conditions in the south, with discontinuous peatland permafrost phenomena northward, and permafrost along the Hudson Bay coast.

Botanical observations and collections from the southern part of the Lowland have been numerous but usually not site-intensive. Summaries of the history of this work (Baldwin, 1953; Dutilly et al., 1954, 1958; Sims et al., 1979) demonstrate that field studies have been concentrated along the forested areas adjacent to major rivers (Dutilly and Lepage, 1952, 1963; Hustich, 1955) and at accessible townsites such as Moosonee and Moose Factory. More casual observations and collections have been made at coastal sites such as Netchi, East, and Mesakonan Points along the south coast (Dutilly and Lepage, 1963), and Nomansland, Cockispenny, Piskwamisk, and Puskwuche (Piskwashi) Points on southwestern James Bay (Dutilly et al., 1954).

The continental penetration by the arctic waters of James and Hudson Bays causes a general southward depression of the subarctic in Ontario and Quebec. This southward expression of subarctic environments in maritime situations parallels that of the Labrador coast and the Aleutian Islands. Even locally, general climatic conditions (Chapman and Thomas, 1968; Hustich, 1955) seem to be less important to local variability of habitats than the microclimatic influences related to proximity to the coast. As well, there are microclimatic effects associated with the paludification of interior wetland sites, such as those associated with discontinuous permafrost features (Cowell et al., 1978).

The development of interior wetlands is related to more than the flatness of terrain; the flat coastal meadows and interior wetlands are characterized by relatively impermeable fine clay and silt substrates. Coastal and interior beachridges are usually sorted coarse sands and fine gravels, while estuarine and stream areas are characterized by sorted mixtures of coarse sediments.

Of major significance to the interpretation and description of coastal habitats is the shallowness of coastal relief and the continuous emergence of a characteristic coastal geomorphology. Although not known precisely, the present rate of isostatic rebound in the study area can be estimated at approximately $1 \mathrm{~m} / 100$ y over the last 1000 years (Hunter, 1970; Webber et al., 1970; Andrews, 1968), having diminished from an estimated rate 6000 y B.P. of $4.4 \mathrm{~m} / 100$ y (Andrews, 1969). From current topographical mapping $(1: 250000 \mathrm{scale})$, the present slope of the 30 to $50 \mathrm{~km}$ wide strip adjacent to southwestern James Bay is less than $1.2 \mathrm{~m} / \mathrm{km}$ (compare with values of $0.8 \mathrm{~m} / \mathrm{km}$ (Hunter, 1970), and $0.6 \mathrm{~m} / \mathrm{km}$ (Kindle, 1923) ). This slope is apparently even less in the immediate vicinity of the Bay. The study areas have rebounded about $50 \mathrm{~m}$ over the last 6000 years, and residual rebound is estimated at $120 \mathrm{~m}$ (Andrews, 1969).

Tides at Shipsands Island average $1.7 \mathrm{~m}$, revealing vegetated tidal flats over $1200 \mathrm{~m}$ wide north of the island and over $900 \mathrm{~m}$ wide at Puskwuche Point. Tides vary considerably along the James Bay coast; tidal mudflats of over $9 \mathrm{~m}$ width have been reported along the western coast (Coombs, 1954). High spring tides, in conjunction with spring river floods, submerge shallow estuarine islands, and exceptional autumn tides as recently as 1972 have completely submerged Shipsands Island. Transects surveyed southeast towards Shipsands Island or Arnold Point can cross more than $2500 \mathrm{~m}$ of mudflat at low tide before encountering vegetation with cover values greater than 10 per cent. 


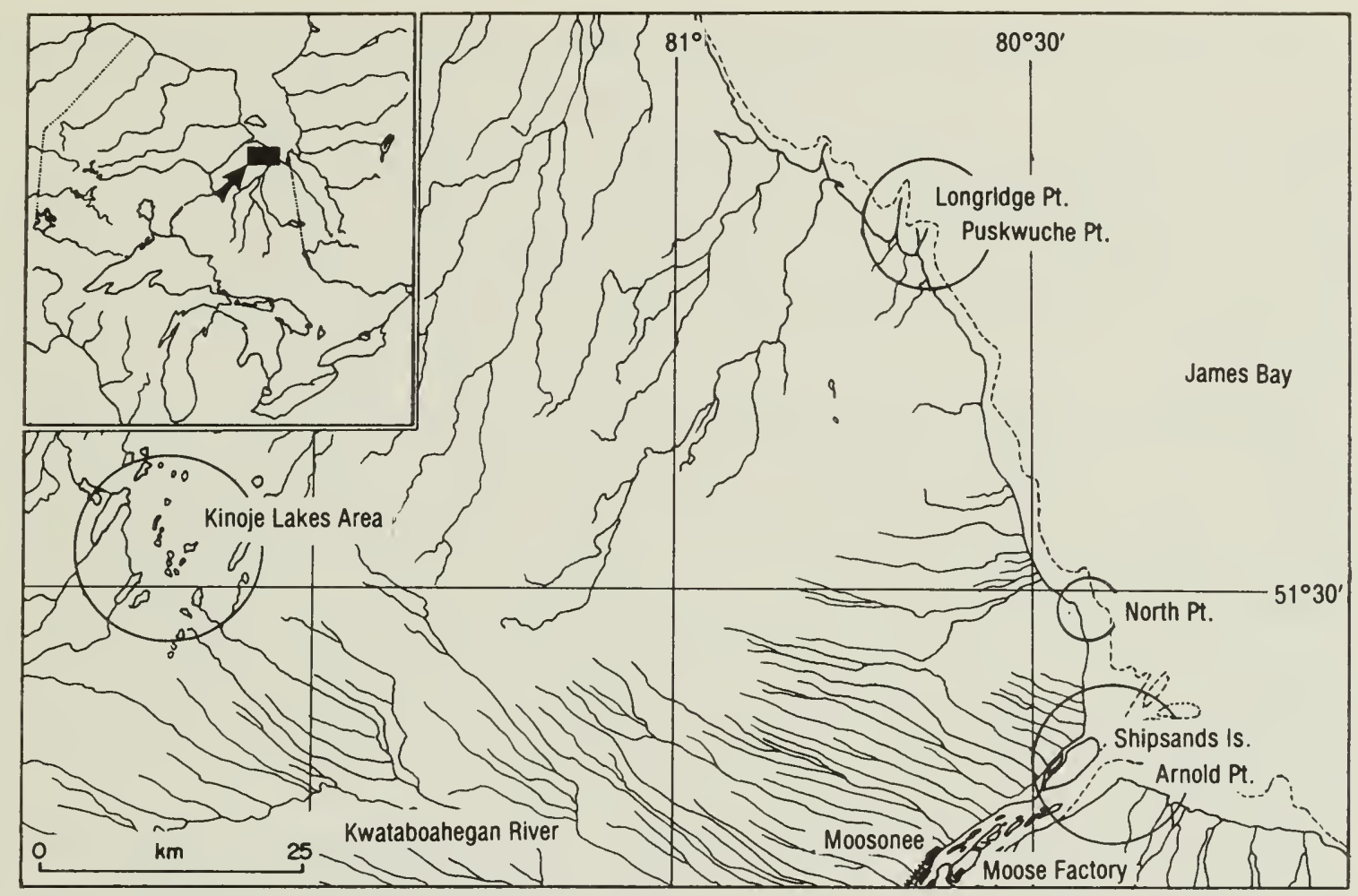

Fig. 1 Study areas, southwestern James Bay.

\section{Materials and Methods}

During the summers of 1972,1974 , and 1976 we participated in habitat inventories of coastal southwestern James Bay. In the first two of these field periods 22 separate transects (more than $14 \mathrm{~km}$ ) were studied and, in some cases, marked for possible replicate study at a later date. In 1972 (Riley and Moore, 1973), five transects on Shipsands Island were established, recording stratification, frequency and cover for $160(1 \mathrm{~m} \times 1 \mathrm{~cm})$ plots along a cross-island transect, and relative frequency and cover for major associations along four other transects. In 1974 (McKay and Arthur, 1975) nine transects were established near Puskwuche Point and eight on Shipsands Island; more than 850 units $(1 \mathrm{~m} \times 1.5 \mathrm{~cm}$ in open sites, $0.5 \mathrm{~m} \times 0.5 \mathrm{~m}$ units for thicket associations) were sampled for frequency, density, and dominance. These latter data were ordered according to major association types to produce species-importance values (based on a total of 300) from data on relative frequency (100), relative density (100), and relative dominance (100). In 1976, reconnaissances of Arnold Point, North Point, Puskwuche Point, and Longridge Point were made. This report is not intended as a detailed presentation of these transect data but as a synopsis of the dominant vascular plant associations.

The major associational series or dominance types refer to relatively homogeneous communities. Most of those mentioned are major associations covering hundreds of hectares along the coast, either in continuous or in mosaic-like patterns. Only a few of the associations mentioned approach the size minimum adopted ( 0.5 hectare). Species-area curves were used in some cases as a rough index of homogeneity. We have not attempted to describe the considerable range of heterogeneity present among the minor associational series. 
Nearly all of the specimens listed for the study areas have been collected since 1972 by the authors. Other collections have been made available to us by J.K. Jeglum, R.A. Sims, G. Tessier, R.D. Elliot, P.F. Maycock, W.J. Crins, and P. Prevett. No systematic attempt has been made to add to the checklist records and collections made before 1972, except when particular specimen records were necessary to make the checklist as complete as currently possible. Voucher material is maintained by the University of Toronto Vascular Plant Herbarium (TRT) and to a lesser extent by other collections (see notes prefacing the checklist).

The distribution maps combine detailed "point" distribution information for areas of specific interest (such as Ontario, northern Manitoba, or northern Quebec) with more general "line" distribution data such as that assembled by Hultén and others referenced on the maps. The latter "line" distributions are not mapped in areas for which "point" distribution data were assembled. Specimen data for stations mapped are stored at the University of Toronto Herbarium. The data were compiled from the herbarium there, and herbaria at the Plant Biosystematics Institute, Agriculture Canada (DAO), the National Museum of Natural Sciences (CAN), and the Great Lakes Forest Research Centre, Environment Canada (SSMF).

The term "disjunction" is used in this paper to imply a geographic separation of at least $400 \mathrm{~km}$ between populations. Of the 31 disjunct species discussed, only Ranunculus cymbalaria is disjunct by less than $500 \mathrm{~km}$ and is considered to have less than conclusive status as a "disjunct" species.

\section{Major Vascular Plant Associations}

Dutilly et al. (1958:13) briefly characterized the associations of the "prairies littorales" of southwestern James Bay: "un zonage bien défini de la végétation, en corrélation apparente avec le degré de salinité du sol, depuis de Puccinellia phryganodes baigné par les marées quotidiennes, passent par le Calamagrostis neglecta touché par les grandes marées, jusqu'à la saulaie de fond de la prairie, qu'atteint pariois les marées d'amplitude exceptionnelle au cours de l'automne". As well as noting the most common species, they commented on the occurrence of particular halophytes, meadow/marsh aquatics, and sedge hybrids, and the most common ridge and thicket species.

In their conspectus of the flora of southern James Bay, Dutilly and Lepage (1963) concentrated on presenting the more important forest (riparian and non-Lowland) associations, but mentioned the major coastal associations as those dominated by Festuca rubra, Calamagrostis neglecta, Juncus balticus, and Hierochloe odorata, listing as well some common co-dominant species. Noting the differences in estuarine sites, mention was made of those associations observed at the mouth of the Harricana River, such as those dominated by Scirpus americanus, S. validus, Senecio congestus, Carex paleacea, Calamagrostis neglecta, and others.

On the basis of sampling at Shipsands Island (estuarine), Pielou and Routledge (1976:372) commented that "in the marshes of James Bay, however, Carex paleacea dominated all but the upper and lower fringes". On the contrary, we found the coastal vegetation to be extremely variable in terms of the dominant species and the range of total cover. In this paper, we outline only the major associational series 
of each formation and, within even this restricted treatment, Carex paleacea marshes are by no means dominant.

The zonation adopted by Glooschenko (1978) is non-hierarchical (Jeglum et al., 1974), combining physiognomic groupings (such as "upper intertidal" zone) with dominance types (such as the "Triglochin-Potentilla" zone). In that study, cover data from three transects sampled at North Point were interpreted as eight specific zones seaward of the thicket communities, with a study of above-ground biomass proceeding on the basis of that zonation.

The classificatory approach adapted here (Jeglum et al., 1974) is not intended to illustrate patterns along environmental gradients, except inasmuch as such gradients may be assumed from the shifts of major associational series (dominance types). The major formations are meadow-marshes and ridges, with development of swamp (thicket and conifer swamp) and upland forest towards the interior. The major physiognomic groupings parallel the coast and are segregated for convenience as intertidal (subject to regular tidal influence), supertidal (subject to spring and other exceptional tides, and consequent marine ice effects), and freshwater (beyond tidal influences). Freshwater meadow-marsh varies from meadow to deep marsh, whereas the intertidal and supertidal meadow-marshes are found in deep water $(15 \mathrm{~cm}$ to $1 \mathrm{~m})$ only in association with streams or estuaries. Supertidal meadow-marsh, ridges, and freshwater meadow-marsh all support shrub-dominated series towards the interior, with freshwater situations tending towards thicket swamp and, eventually, conifer swamp. For the purposes of comparison, estuarine sites are presented separately from strictly coastal sites.

Vascular plant collection data for interior wetlands around the Kinoje Lakes are included for reference and comparison on species checklists, but no details of plant associations are offered. The major formations (Jeglum et al., 1974) observed in the Kinoje Lakes area include bogs (open sphagnum bogs, bog pools, low shrub bogs, low shrub treed bogs, shrub-rich treed bogs and treed bogs), fens (moss fen, graminoid fen, low shrub fen, shrub-rich treed fen, treed fen), meadow-marsh (shallow meadow marsh, deep meadow marsh), swamp (thicket and conifer), and upland (beachridge) and riparian (levee) forest associations.

\section{Coastal Communities}

\section{Intertidal Marsh}

The major intertidal series is dominated by Puccinellia phryganodes, with cover varying from less than 5 per cent to more than 90 per cent shoreward. $P$. phryganodes, a prostrate asexual grass of salt marsh habitats (Sørensen, 1953), has a wide maritime distribution largely due to the effects of breakage, ice rafting and shoreline currents. The most important associates of this series, all of which are the dominant species of other intertidal series, are Plantago maritima, Carex paleacea, Potamogeton filiformis, $P$. pectinatus, Potentilla anserina var. groenlandica, Scirpus maritimus var. paludosus, and Senecio congestus. Other important species of this series are Ranunculus cymbalaria, Stellaria humifusa, Atriplex patula, Salicornia europaea, Spergularia canadensis, Juncus bufonius, Triglochin palustris, Eleocharis 


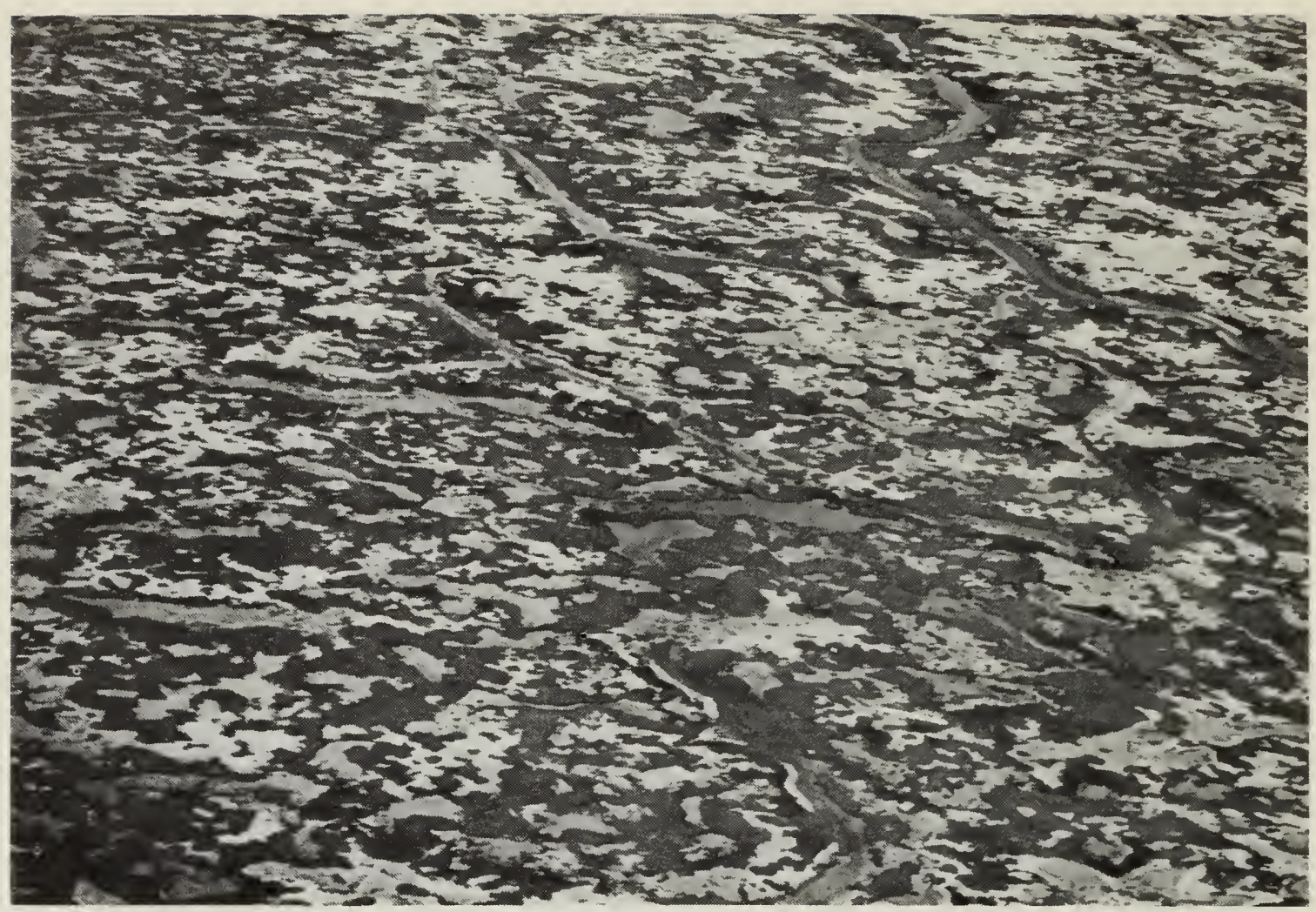

Fig. 2 Low tide reveals clearly the intertidal mosaic of Puccinellia phryganodes sward, pool-pannes, and linking drainways that are characteristic of southwestern James Bay.

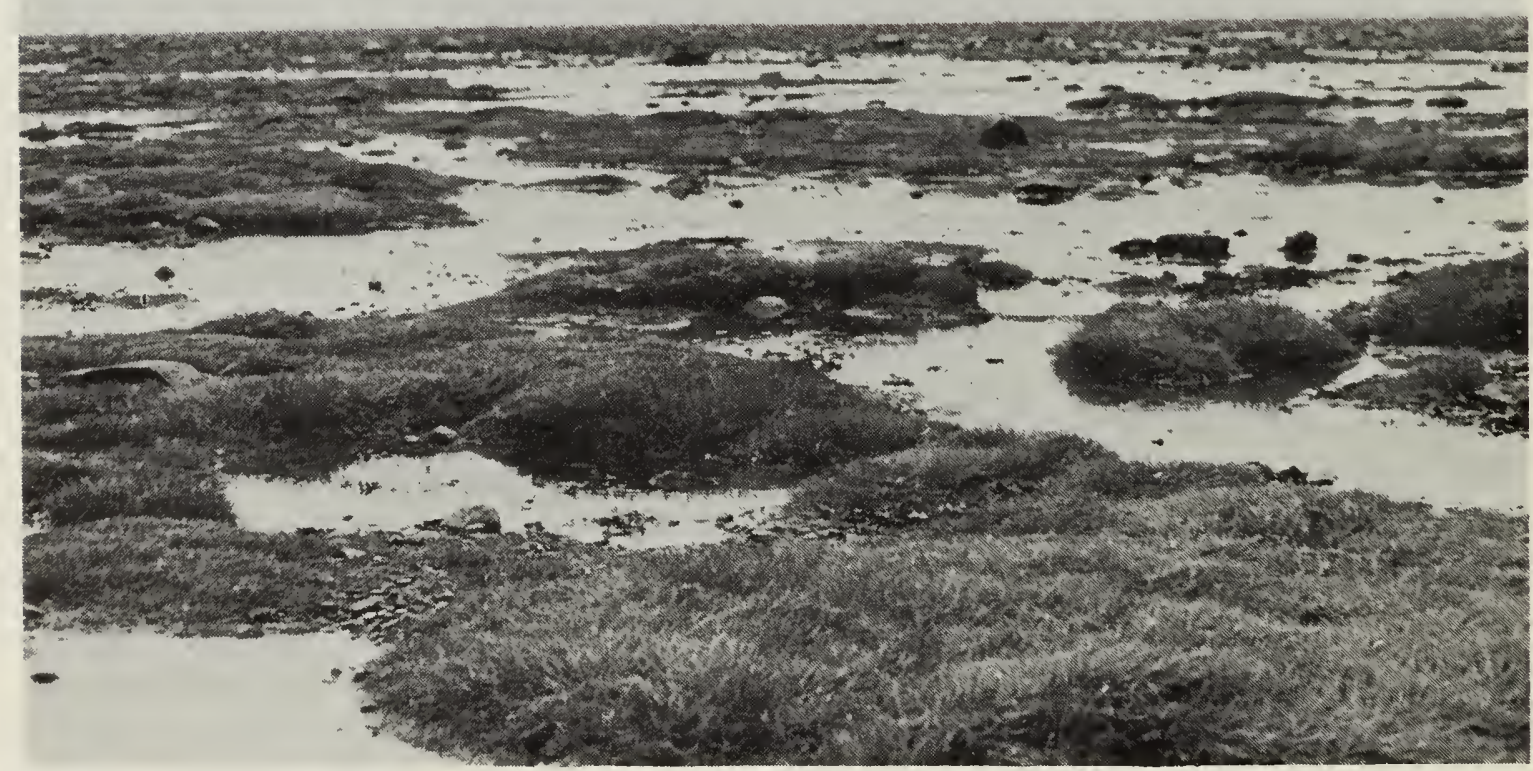

Fig. 3 On the ground, the shallow relief of the intertidal mosaic is apparent. This relief, caused by ice rafting, tidal erosion, and stabilization by clonal vegetation, may be partially responsible for similar mosaic patterns in supertidal meadow-marsh and in interior bogs and fens. 
palustris, and Glaux maritima. The surface display of this series is, especially shoreward, a mosaic pattern (Figs. 2, 3), with interstitial pondings and drainage channels of lesser elevation than the Puccinellia sward. This pattern is thought to be largely a function of widespread ice rafting, which results in masses of salt marsh vegetation (units often exceeding 2-3 m) which have been frozen into the shorebound ice, being lifted by the breakup pattern of high spring tides, and then either relocated by floating to other intertidal areas, pushed to the high tide line, or broken up at sea (Redfield, 1972). Once established, this panne-sward pattern of topographic discontinuity persists through the supertidal meadow-marshes as well. The habitat of more obligative halophytes such as Salicornia europaea, Spergularia canadensis, Suaeda calceoliformis, and Plantago maritima would suggest that ice rafting may remove impermeable sediments, resulting in increasingly saline conditions as coarser sediments form evaporative pannes beyond the level of normal high tides. Linear patterns indicating drift ice damage to intertidal marshes are also present.

Panne marsh pools in which shallow waters persist through low tide comprise other major associational series, most often dominated by single species, such as Scirpus maritimus var. paludosus, Eleocharis palustris s.l., Carex paleacea, Senecio congestus, Hippuris vulgaris f. maritima, Potamogeton filiformis, or Zannichellia palustris. Where Potamogeton filiformis and $P$. pectinatus dominate, common associate species are Zannichellia palustris, Ruppia maritima, Eleocharis palustris, Scirpus maritimus var. paludosus, and Hippuris vulgaris. Eleocharis palustris and Scirpus maritimus var. paludosus can form single-species stands with cover values ranging from less than 10 per cent to more than 80 per cent. Carex paleacea, Hippuris vulgaris, and Senecio congestus are the most common associates.

Shoreward, series dominated by Carex paleacea, Eleocharis palustris, or Potentilla anserina var. groenlandica become increasingly frequent. Hordeum jubatum, Festuca rubra, Utricularia vulgaris, Juncus balticus, and Scirpus rufus var. neogaeus appear. The transition to supertidal meadow-marsh is often well defined along this coast by the orientation of beach ridges as critical barriers to normal tide levels. Coastlines undergoing significant isostatic adjustment produce unique displays of parallel and arcuate beach ridges, and spits such as at Puskwuche and Longridge Points. Their presence often diminishes the potential expression of transitional associations at the limit of normal high tide. However, even in areas uninterrupted by beach barriers stormtide deposition of debris often contributes to reasonably distinct borders between major associational series.

\section{Supertidal Meadow-Marsh}

Graminoid meadows dominate all non-beachridge areas (Fig. 4). Combined transect results of supertidal areas sampled for importance values indicate the major species to be Festuca rubra, Potamogeton filiformis, Eleocharis palustris, Carex paleacea, Ranunculus cymbalaria, Juncus balticus, and Puccinellia phryganodes. This ranking blends mosaic discontinuities; for example, Potamogeton filiformis occurs in standing pools and slow drainways.

The Festuca rubra series dominate the sward areas, nearly always in association with Potentilla anserina var. groenlandica. Festuca rubra-Hordeum jubatum, Festuca rubra-Deschampsia cespitosa, and Festuca rubra-Scirpus rufus var. neogaeus are also common series; however, Festuca rubra almost invariably has cover values more than 50 per cent and is rarely a secondary element of other series 


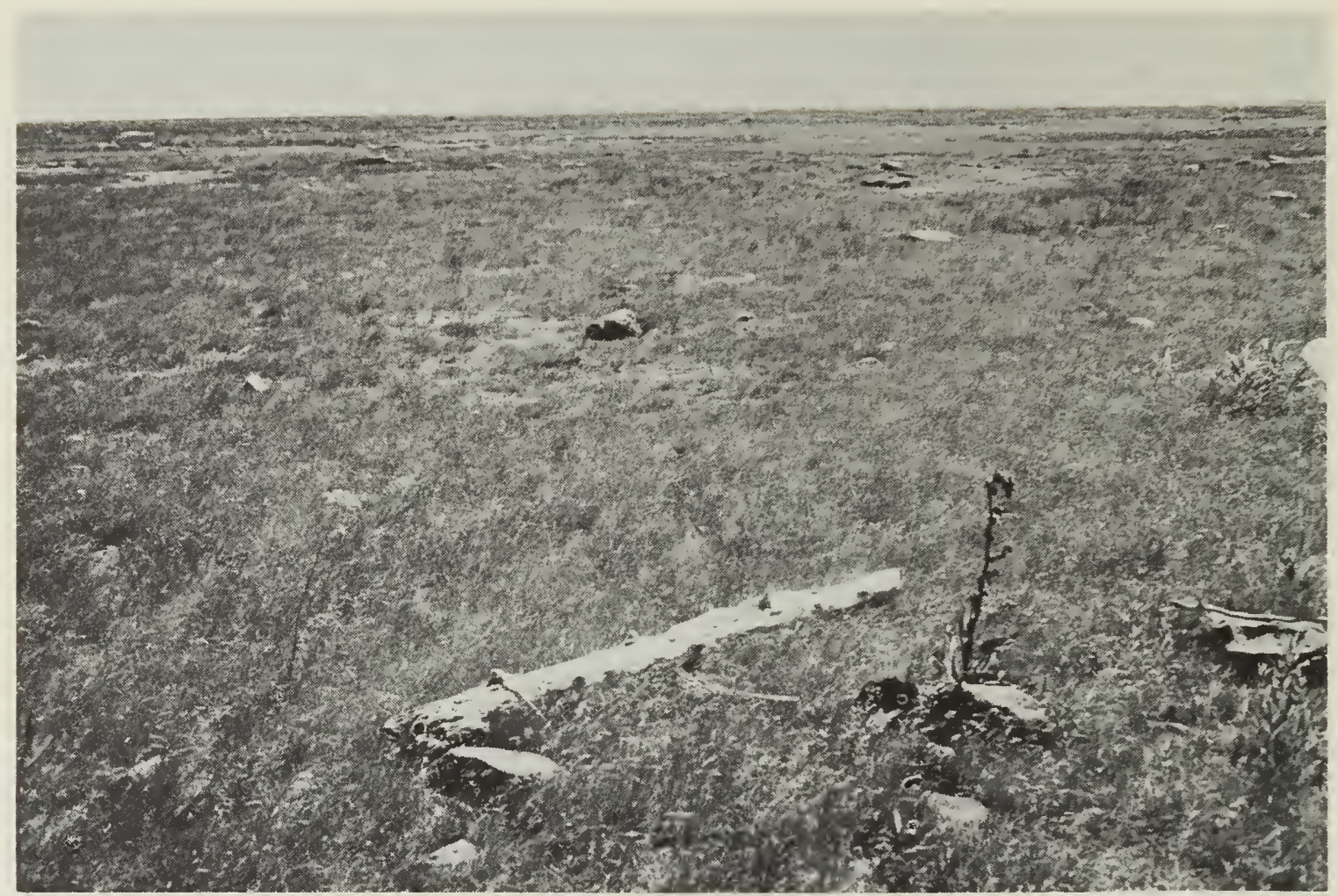

Fig. 4 A typical supertidal meadow at Longridge Point, dominated by Festuca rubra, Potentilla anserina var. groenlandica, Hordeum jubatum, and Deschampsia cespitosa var maritima. The herb in the right foreground is Prenanthes racemosa.

(except on the drier verges of beachridges). Other predictable associates of this series include Rhinanthus crista-galli, Lomatogonium rotatum, Aster johannensis, Puccinellia phryganodes, and Ranunculus cymbalaria. In such situations, Scirpus rufus var. neogaeus can dominate small areas.

On coarser sediments and drier sites, a Juncus balticus-Calamagrostis stricta series is common, with Lathyrus palustris, Parnassia palustris var. neogaea, and other species subordinate. Other meadows are dominated by a Calamagrostis stricta series, with Deschampsia cespitosa (occasionally dominating), Festuca rubra, Hordeum jubatum, Juncus balticus, Eleocharis palustris, and Carex paleacea. Forbs such as Castilleja septentrionalis, Cicuta maculata, C. mackenzieana, Achillea millefolium, and Lathyrus palustris are also common.

In the shallow supertidal marsh pools and drainways, the dominant series involve fewer species, in more variable associations. Carex paleacea (often more than 80 per cent cover) forms one series; associates include Utricularia vulgaris, Hippuris vulgaris, Ranunculus aquatilis, Cicuta maculata, Epilobium leptophyllum, and E. palustre. Shallow water series include those dominated by Eleocharis palustris, Hippuris vulgaris, Potamogeton filiformis, Myriophyllum exalbescens, and Zanichellia palustris. Overall cover by these seriés can be sparse in running shallow streams, or congested in large pools. Some secondary species are Utricularia vulgaris, Potamogeton gramineus, P. pusillus, Ranunculus aquatilis, Ruppia maritima, Sparganium chlorocarpum, Sium suave, and Senecio congestus.

\section{Low Raised Beachridge}

Long shallow ridges of coarse gravels and sands parallel the bay and are often surrounded by intertidal marsh or bare mud flat. They can also act as continuous 
breaks between intertidal and supertidal series. Vegetation on such parallel ridge systems is invariably sparse; Elymus mollis, Artemisia tilesii, and Lathyrus maritimus are usually co-dominant. The other important members of this series are Honkenya peploides, Hordeum jubatum, Stellaria longipes, Rhinanthus crista-galli, Gentianella amarella, and Fragaria virginiana. On the seaward edge of such ridges, Polygonum fowleri, P. ramosissimum, Puccinellia lucida, Plantago maritima, and Atriplex spp. occur. On the inshore slope of the ridges, transitional assemblages merge into supertidal series; examples of such communities include: (i) Festuca rubra-Rhinanthus crista-galli-Primula stricta-Parnassia palustris var. neogaea; (ii) Festuca rubra-Mentha arvensis-Juncus balticus-Lathyrus palustris; and (iii) Juncus balticus-Festuca rubra-Prenanthes racemosa.

\section{Older Raised Beachridge}

The older ridges vary from open to shrub-rich in exposed sites, and are thicketed or treed toward the interior. The Elymus mollis-Artemisia tilesii series of the first beachridges becomes dense; associates such as Aster johannensis, Festuca rubra, Achillea millefolium, and Lathyrus maritimus give way to dominant cover of Fragaria virginiana, and occasionally Juncus balticus. Other subdominant elements include Gentianella amarella, Agropyron trachycaulum, Prenanthes racemosa, Heracleum lanatum, Urtica dioica ssp. gracilis, Botrychium spp., and Draba spp.

Shrub-rich series are dominated by associations such as Shepherdia canadensisRibes oxyacanthoides-Elymus mollis-Fragaria virginiana, Elaeagnus commutataShepherdia canadensis-Ribes oxyacanthoides-Fragaria virginiana, Populus balsamifera-Ribes oxyacanthoides-Shepherdia canadensis-Juniperus spp., and Ribes oxyacanthoides-Artemisia tilesii-Fragaria virginiana-Shepherdia canadensisPopulus balsamifera. The less exposed back ridges and ridge slopes support more mesic and heterogeneous associations. Examples include: (i) Salix glauca-Juncus balticus-Lathyrus palustris; (ii) Salix brachycarpa/candida/glaucophylloides-Cornus stolonifera-Equisetum pratense; (iii) Betula pumila var. glandulifera-Salix spp.; (iv) Betula pumila var. glandulifera-Larix laricina-Picea glauca-Shepherdia canadensis; and (v) Myrica gale-Populus balsamifera-Betula pumila var. glandulifera.

Treed and thicketed ridges develop fully beyond the extent of typical open coastal habitats (Fig. 5) Picea glauca, Populus balsamifera, Salix spp., and Larix laricina dominate such sites, with species such as Arctostaphylos uva-ursi, Pyrola asarifolia, and Orthilia secunda, as well as feather mosses and cladonia lichens, as frequent associates.

\section{Freshwater Meadow Marsh}

Between the raised beachridges towards the interior, organic freshwater wetlands develop, eventually producing ombrotrophic bog and minerotrophic fen and swamp. However, such paludified acid habitats are not common features close to the coast, where rich and varied meadow-marsh predominates (Fig. 6).

Areas dominated by Typha latifolia are often extensive, with Utricularia vulgaris, Carex aquatilis, C. retrorsa, Hippuris vulgaris, Lysimachia thyrsiflora, Geum rivale, and Lemna trisulca also frequently present. There are many other shallow marsh-meadow associations: (i) Carex rostrata-C. aquatilis; (ii) Carex recta- $C$. aquatilis-Geum rivale-Menyanthes trifoliata; (iii) Carex limosa-C. recta-C. 


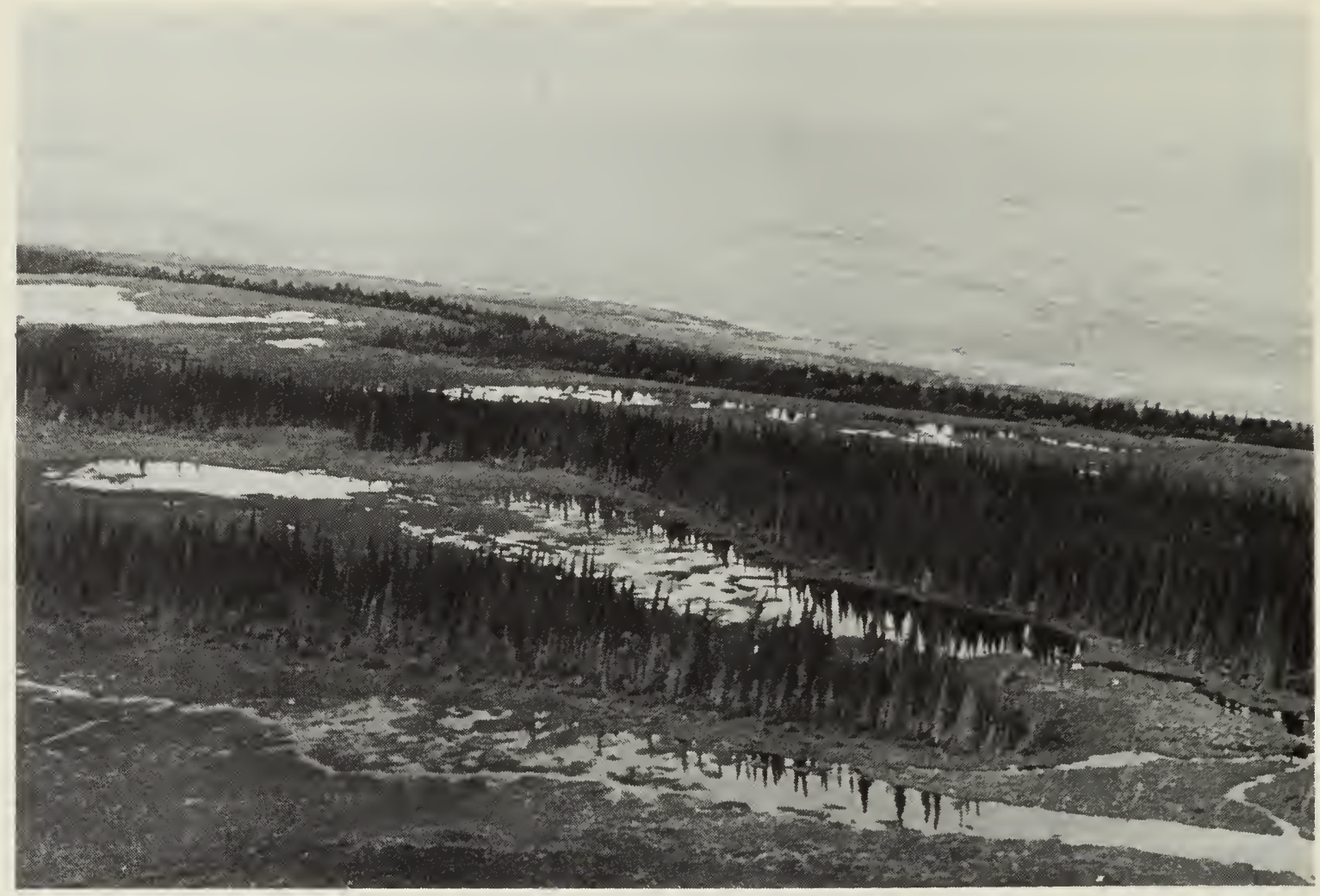

Fig. 5 Looking across the wooded coastal ridges just south of Puskwuche Point, an area where the expression of supertidal meadows is minimal but inter-ridge freshwater marshes are common.

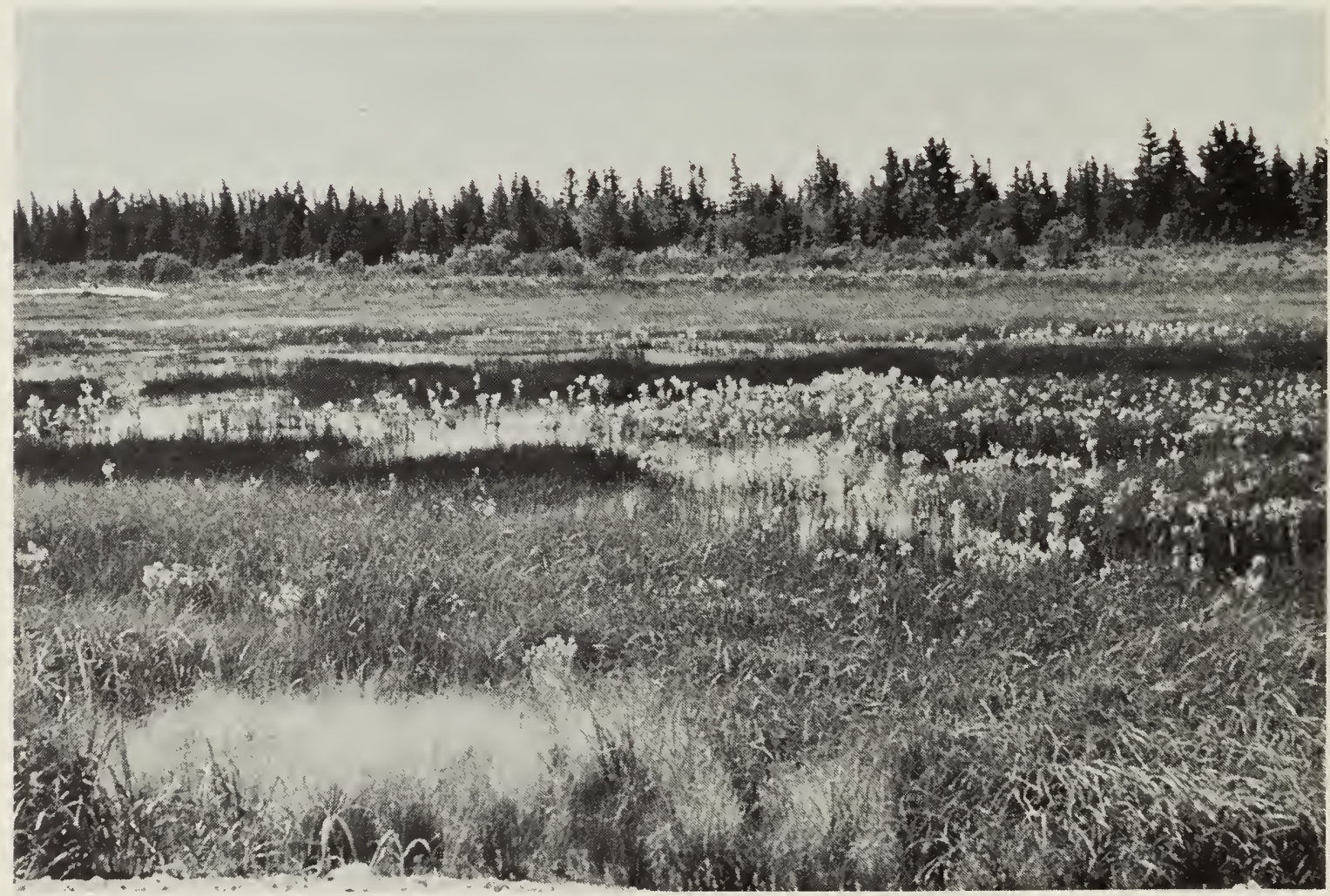

Fig. 6 Meadow-marsh at Puskwuche Point, dominated by Juncus balticus, Senecio congestus, and Carex paleacea in the foreground, and grading into a less brackish Festuca rubra association towards the wooded ridge in the background. 
aquatilis-C. diandra-C. saxatilis; (iv) Carex retrorsa-C. limosa-C. diandra; (v) Scirpus americanus-Sparganium chlorocarpum; (vi) Potentilla palustris-Carex limosa; (vii) Menyanthes trifoliata-Utricularia vulgaris-Carex aquatilis; (viii) Menyanthes trifoliata-Salix serissima-Carex lanuginosa-C. limosa.

Shrub-rich meadow-marshes are dominated by willows or, infrequently, by Myrica gale, usually growing with sedge and cat-tail. Willow-alder thickets also occur; ground cover in such sites is often similar to nearby supertidal graminoid meadow, for example, Calamagrostis stricta-Lathyrus palustris-Castilleja septentrionalisAchillea millefolium, or Juncus balticus-Calamagrostis stricta-Lathyrus palustris. There is undoubtedly considerable variability in the composition of freshwater marshes inland; however, they have not been surveyed as intensively as those in the immediate vicinity of the coast.

\section{Estuarine Communities}

\section{Intertidal Marsh}

The flow of the Moose River into the Bay reduces significantly the scope of halophytic development in the intertidal areas, particularly east of the rivermouth, downcurrent of the counterclockwise James Bay current. Communities are more varied than in coastal intertidal situations, while the patterns of rivermouth sedimentation appear to override or prevent the formation of panne-sward mosaics, resulting instead in broader, more gradually varying associations. Puccinellia phryganodes and Puccinellia phryganodes-Triglochin palustris-Salicornia europaea occur to a much lesser extent than further north in nonestuarine sites. Halophytic associations are more frequent on the tidal flats north of Shipsands Island, where the Moose River outflow has little effect. A brief study of the tidal pattern of salinity in the river between Arnold Point and Shipsands Island showed a relatively strong upriver surge, confined to the bottom strata, of cold saline James Bay water for only a short period at high tide.

Carex paleacea shows the highest importance values overall; it can have cover values greater than 90 per cent or it can be accompanied by other species in associations with importance values (refer to Materials and Methods and Fig. 7) such as Carex paleacea ${ }^{85}$-Potentilla anserina var. groenlandica ${ }^{35}$-Ranunculus cymbalaria $^{32}$-Triglochin maritima ${ }^{23}$, and Carex paleacea ${ }^{102}-F_{\text {estuca rubra }}{ }^{33}$ Potentilla anserina var. groenlandica ${ }^{32}$-Triglochin maritima ${ }^{14}$. Other less important, frequently occurring species are Scirpus maritimus var. paludosus, Eleocharis palustris, Senecio congestus, Carex recta, C. aquatilis, Scirpus validus, and Cicuta maculata.

The widespread Eleocharis palustris series often begins far out on the tidal flats, as sparse circular lenses that become more dense shoreward, either as pure colonies or most commonly associated with Scirpus validus, Hippuris vulgaris, or Scirpus maritimus var. paludosus. Other associates include Sagittaria latifolia, Eleocharis acicularis, Juncus nodosus, and Plantago maritima. The three most common associates mentioned above dominate other series: (i) Scirpus validus, Scirpus validus-Eleocharis palustris-Ranunculus cymbalaria-Sium suave-Carex paleacea, 


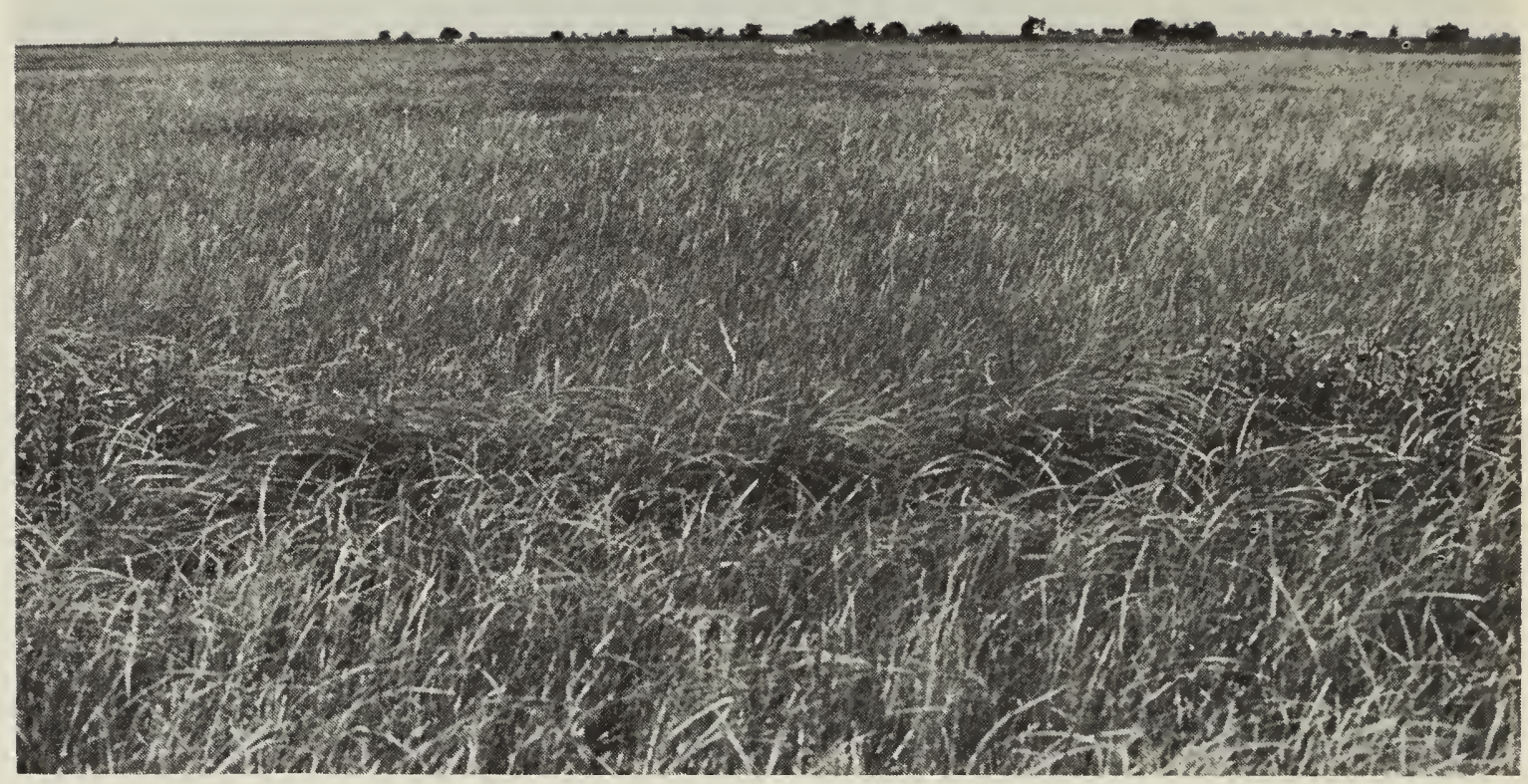

Fig. 7 The extensive intertidal meadow-marsh at the north end of Shipsands Island is dominated by Carex paleacea, Potentilla anserina var. groenlandica, Ranunculus cymbalaria, and Trichochin maritima.

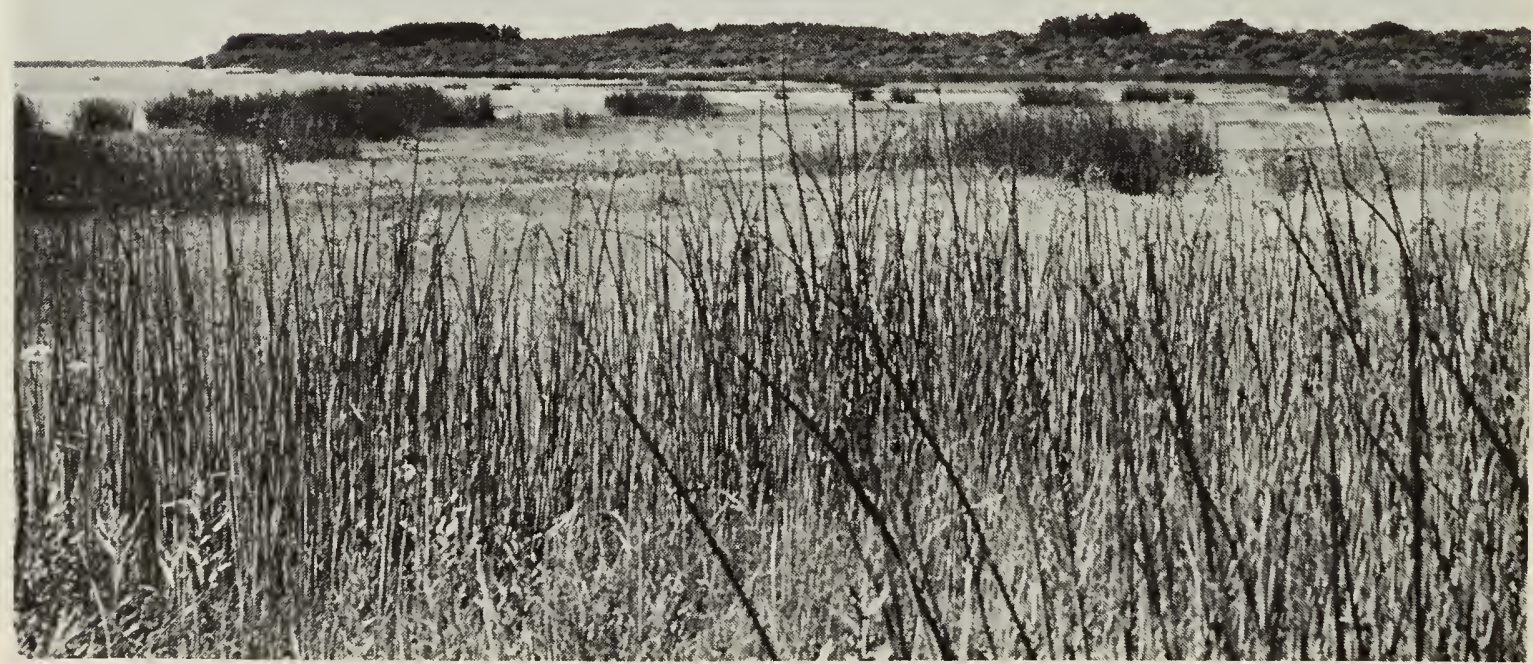

Fig. 8 At low tide, looking up the Moose River across the intertidal estuarine marsh at the south end of Shipsands Island, with Scirpus validus, S. maritimus, and Eleocharis palustris dominating. 
Scirpus validus-Hippuris vulgaris-Alisma plantago-aquatica; (ii) Hippuris vulgarisEleocharis palustris; and (iii) Scirpus maritimus var. paludosus, Scirpus maritimus var. paludosus-Eleocharis palustris-Hippuris vulgaris, Scirpus maritimus var. paludosus-Carex mackenziei.

Potentilla anserina var. groenlandica dominates one of the few important non-cyperaceous series, associated with Carex paleacea, Aster johannensis, and Hierochloe odorata, among others. Another such series is that of the impressive Senecio congestus, dominating mixed associations with Eleocharis palustris, Puccinellia phryganodes, Catabrosa aquatica, Carex paleacea, Salicornia europaea as well as many more species.

The other less frequent series are estuarine intertidal associations without halophytic affinities. A few of them are Sagittaria latifolia-Eleocharis palustrisScirpus validus, Equisetum fluviatile-Juncus nodosus-Carex recta-Eleocharis palustris, Juncus nodosus-Equisetum fluviatile-Carex rostrata, Scirpus americanus-Scirpus validus-Eleocharis palustris-Triglochin palustre, Carex recta-C. aquatilis, Bidens hyperborea-Sagittaria latifolia-Alisma plantagoaquatica, and Lysimachia thyrsiflora-Hippuris vulgaris-Sparganium spp. Shipsands Island is at present an island in little more than name. The streams separating it from the mainland are navigable only at high tide (Fig. 8). Comparison of the provincial air-photo series of 1953, 1960, and 1972 with historical materials such as the "Map of part of Northern Ontario and Eastern Keewatin" (Wilson, 1903) attest to the impact of alluvial and isostatic processes in this coastal estuary.

\section{Supertidal Meadow-Marsh}

These associations bear closer similarity to meadow-marsh of the comparable coastal formations than do intertidal associations. The important Festuca rubra series appear to have a more variable composition than in strictly coastal situations, with Potentilla anserina var. groenlandica, Ranunculus cymbalaria, Rhinanthus crista-galli, Hordeum jubatum, Cicuta maculata, and Hierochloe odorata important secondary components. Rumex occidentalis, Carex paleacea, Deschampsia cespitosa, Agrostis gigantea, Scirpus rufus var. neogaeus, and Juncus balticus are also common. In such areas, Rhinanthus crista-galli can have high importance values, dominating a minor series with such species as Festuca rubra, Castilleja septentrionalis, Hierochloe odorata, Epilobium leptophyllum, and Lathyrus palustris.

Series of drier sites include Juncus balticus (often greater than 70 per cent cover)-Petasites sagittatus-Festuca rubra (with Solidago uliginosa, Salix cordata, Senecio aureus, Poa palustris, Lathyrus palustris, and others), a minor Anemone canadensis-Thalictrum venulosum-Smilacina stellata series, and an Agrostis gigantea series.

In wetter sites behind the shallow ridges of Arnold Point, several uncommon series are important: Carex recta-Equisetum variegatum-Angelica atropurpurea, Carex recta-Menyanthes trifoliata-Angelica atropurpurea, Equisetum variegatum, and Carex limosa-paupercula-C. aquatilis-Rumex occidentalis. This meadow-marsh vegetation occurs with large willows in a parkland coastal meadow beginning a good distance inland (1200 $\mathrm{m}$ south from Arnold Point). Where lateral drainage of these areas is impeded by ridges, numerous freshwater marshes develop. 


\section{Low Raised Beachridge}

Beachridges are not well developed at the mouth of the Moose River, although there is a weak and shallow expression of them across Arnold Point (Fig. 9), and some vague lengthwise ridges along the interior of Shipsands Island. They are not the well-drained coarse materials of coastal ridges but are composed mainly of finer alluvial materials. They are characterized by riparian and tidal debris, with a considerable number of species subordinate to the dense low shrub willow series. Salix candida, S. cordata, S. lucida, S. planifolia, S. interior, and Myrica gale dominate, while the most important herbaceous species are Lathyrus palustris, Vicia cracca, V. americana, Fragaria virginiana, Deschampsia cespitosa, Festuca rubra, Carex paleacea, Erigeron philadelphicus, Epilobium ciliatum, Euphrasia arctica, Thalictrum venulosum, Senecio aureus, and Prenanthes racemosa.

\section{Dune-Gravel Shore}

The southeast shore of Shipsands Island (Fig. 10) is a bank scoured by spring breakup, with some dune-lagg formations. Although in some ways comparable floristically to a more mature coastal beachridge, it is a much more unstable environment, with flooding and erosion changing the shoreline habitats from year to year. Furthermore, this seasonally dry shoreline shows the effect of downriver plant dispersal in a manner not comparable to coastal beachridges.

The common shoreward colonizers are Elymus mollis, Honkenya peploides, Hordeum jubatum, and Plantago maritima, but these do not form homogeneous associations as in other coastal situations. In the more widespread and stable dune-lagg sites, varied and highly productive associations predominate (some transects' cover values total $300-400$ per cent). The overall importance values for the transects are Vicia cracca $^{28}$-Juncus balticus ${ }^{24}$-Angelica atropurpurea ${ }^{21}$-Equisetum pratense ${ }^{18}$-Glyceria striata ${ }^{16}$-Thalictrum venulosum ${ }^{15}$-Anemone canadensis ${ }^{14}$, etc., with more than 45 species present, none really dominating. Examples include the following series: (i) Juncus balticus-Sonchus arvensis-Vicia cracca-Festuca rubraCicuta maculata-Carex paleacea-Trifolium hybridum; (ii) Vicia cracca-Lathyrus palustris-Aster johannensis-Anemone canadensis-Heracleum lanatum-Solidago uliginosa-S. graminifolia-S. canadensis; (iii) Cirsium muticum-Equisetum arvenseLigusticum scothicum-Salix interior-Achillea millefolium; (iv) Trifolium hybridumLigusticum scothicum-Spartina pectinata-Castilleja septentrionalis-Vicia cracca; (v) Festuca rubra-Deschampsia cespitosa-Juncus balticus; (vi) Deschampsia cespitosaJuncus balticus; and (vii) Equisetum arvense-Bromus ciliatus.

Densely thicketed dune-lagg communities are present, comprised of such series as: (i) Salix interior; (ii) Salix cordata-S. interior; and (iii) Salix cordata-Heracleum lanatum-Vicia cracca-Solidago uliginosa.

The open plant communities on Shipsands Island have been modified dramatically over periods of time as brief as two years. For example, the southeastern shore of the island was found to have a more developed sand beach flora and backbeach halophyte associations in 1974 than in 1972 . This same shore was heavily sedimented in the spring of 1976 or 1977 , so that some backbeach meadows became dominated by dense strands of Triglochin maritimum and Prenanthes racemosa. Interior streams became flanked by bands of vigorous and dense Ligusticum scothicum. Neither of 

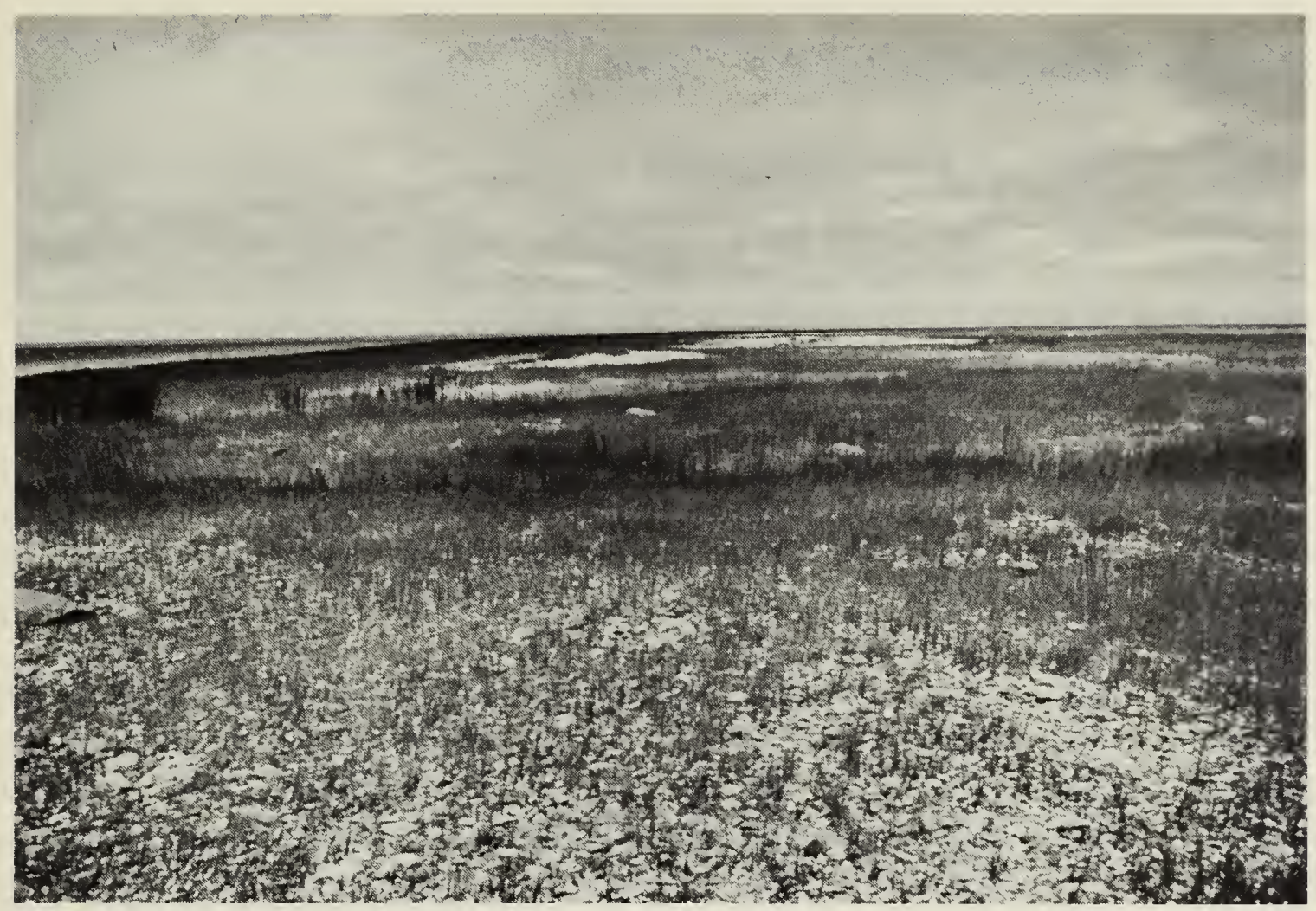

Fig. 9 A shallow and immature beachridge at Arnold Point. Such estuarine ridges are flooded by high tides and high river levels, often enough to prevent accumulation of organic materials.

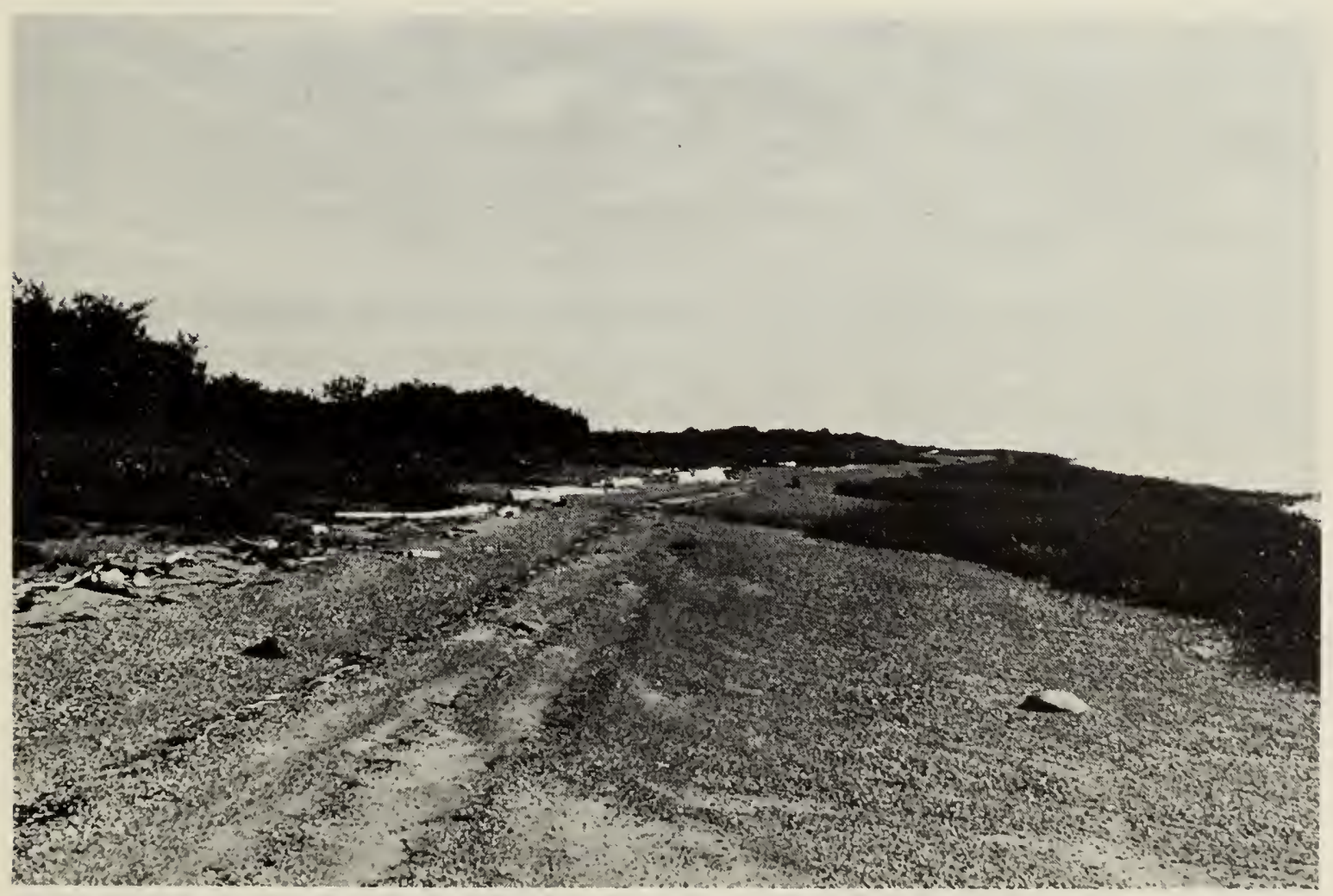

Fig. 10 The river shore along southeast Shipsands Island rises relatively abruptly and supports a number of beachridge associations as well as dune-lagg communities. The shores and thickets are ice-scoured by spring breakup and floods. 
these conspicuous associations, reported to the authors by P.F. Maycock (1978), were noted previously.

\section{Willow Thickets and Freshwater Marsh}

Immediately behind the eastern shore of Shipsands Island is a series of small raised lagg pools (up to $30 \mathrm{~m}$ diameter, $5 \mathrm{~m}$ deep), containing variable combinations of Ranunculus aquatilis, Potamogeton filiformis, Myriophyllum exalbescens, Ceratophyllum demersum, and Chara sp. Most of the estuarine freshwater marsh is, however, confined to the shallower interior drainage channels and trapped backridge areas, supporting associations such as Carex paleacea-Poa palustris, Typha latifolia, Bidens hyperborea-Sagittaria latifolia, Ranunculus aquatilis-Hippuris vulgarisPotamogeton filiformis, and Scirpus americanus. They merge into supertidal meadow-marsh series and are usually not widespread, but rather, transitional between the interior streams and adjacent thickets or meadows.

Dense thickets cover all of the southern end of the island. Examples of these thicket associations are: (i) Alnus rugosa ${ }^{89}$-Glyceria grandis $^{36}$-Anemone canadensis $^{33_{-}}$ Agrostis gigantea ${ }^{21}$-Thalictrum venulosum ${ }^{19}$; (ii) Salix interior ${ }^{48}$-Alnus rugosa ${ }^{36}$. Glyceria grandis ${ }^{23}$-Anemone canadensis ${ }^{18}$-Equisetum pratense ${ }^{16}$-Vicia cracca $^{15}$ Carex interior ${ }^{13}$-Campanula uliginosa ${ }^{13}$-other Salix spp. ${ }^{31}$; (iii) Salix interior ${ }^{60}$. Anemone canadensis ${ }^{50}$-Agrostis gigantea ${ }^{36}$-Petasites sagittatus ${ }^{36}$-Equisetum pratense ${ }^{35}$-Impatiens biflora ${ }^{32}$-Vicia cracca $^{26}$; (iv) Salix serissima ${ }^{35}$-Alnus rugosa ${ }^{34}$-Pyrola asarifolia ${ }^{25}-$ Rubus acaulis ${ }^{25}$-Carex interior ${ }^{17}$-Equisetum pratense $^{16}$; (v) Salix serissima ${ }^{42}$-Equisetum variegatum ${ }^{25}$-Alnus rugosa ${ }^{21}$-Juncus balticus $^{20}$-Galium labradoricum ${ }^{20}$-other Salix spp. ${ }^{36}$.

\section{Floristic Analysis}

\section{Affinities and Disjunctions}

In comparison with the varied flora of riparian forests along the major rivers entering southwestern James Bay, with their characteristic boreal elements penetrating to the coast (Hustich, 1955; Dutilly and Lepage, 1963), there is a striking homogeneity about the landscape and flora of open coastal wetlands between the Albany and Moose Rivers. Dutilly and Lepage (1963) reported 777 species of vascular plants in their work on the flora of the northern rim of the Clay Belt, the edge of the Laurentian Shield and the James Bay Lowland of northeastern Ontario and northwestern Quebec. For the Lowland sites reported here, an estimate of 400 species is probably accurate, in comparison with an estimated 800 species for the Hudson Bay Lowland as a whole (Hustich, 1957; Lepage and Baldwin, 1959).

The variability of habitat coincident with this largely species-poor flora exists in its areal display, degree of coastward compaction, proximity to estuaries, and complexity of ridge formation. Subarctic elements extend to the southernmost part of the Bay on exposed points and spits, and on offshore islands. These elements are much more prevelant on the Precambrian formations of the east coast of the Bay, and on the Ontario coast north of Akimiski Island. 


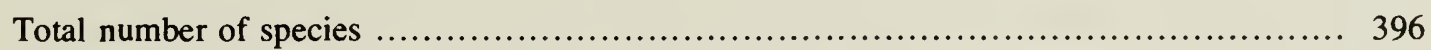

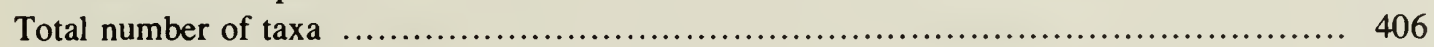

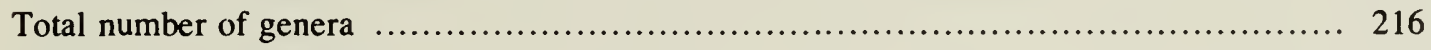

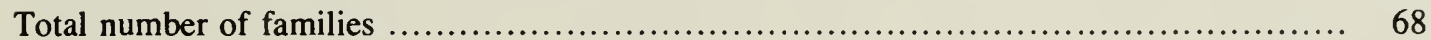

Number of taxa: Shipsands Island, Arnold Point .................................. 229

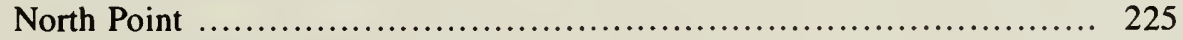

Longridge and Puskwuche Points .............................. 221

Kinoje Lakes area .............................................. 185

All coastal sites ................................................. 273

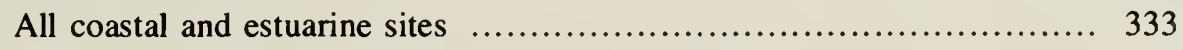

Number $(\%)$ of Kinoje Lakes area taxa not occurring in coastal habitats ................. $72(39 \%)$

Number (\%) of coastal and estuarine taxa not occurring in the Kinoje Lakes area ......... $219(66 \%)$

Number (\%) of Longridge and Puskwuche Points taxa not occurring

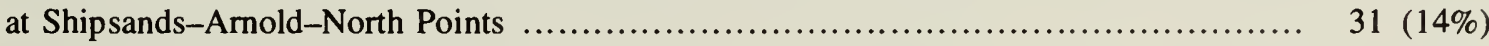

Number (\%) of Shipsands-Arnold-North Points taxa not occurring

at Longridge and Puskwuche Points

Number (\%) of Longridge and Puskwuche Points taxa not occurring

at North Point

Number (\%) of North Point taxa not occurring at Longridge and Puskwuche Points ....... $51(22 \%)$

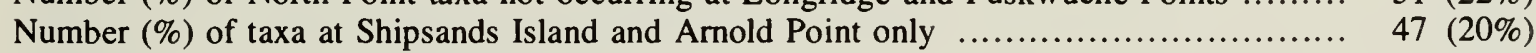

Number $(\%)$ of taxa at North Point only ......................................... $15 \quad(6 \%)$

Number $(\%)$ of taxa at Longridge and Puskwuche Points only ........................ $27(12 \%)$

Number $(\%)$ of taxa at Kinoje Lakes area only .................................... $72(39 \%)$

Number $(\%)$ of taxa at North, Longridge, and Puskwuche Points only ................. $70 \quad(25 \%)$

Of the areas studied in detail, Longridge and Puskwuche Points are the most exposed to the cooling influence of the Bay. Subarctic species such as Trisetum spicatum, Festuca brachyphylla, Draba aurea, D. incana, Androsace septentrionalis (Fig. 11), Gentianella detonsa spp. nesophila (Fig. 32), Poa pratensis var. alpigena, and Chrysanthemum arcticum ssp. polare were found only at Longridge and Puskwuche Points. This is not a function of a more northern position among the sites reported here, but rather of more effectively northern microhabitats; most of these species are known from more southern parts of the Bay such as Buoy's Bluff and Mesakonan Point.

In some cases anomalies may be a function of uneven collection coverage; Cypripedium passerinum and Phleum alpinum were collected at North Point but not elsewhere. Similarly, northern elements not expected in the study area may have been overlooked. For example, Ranunculus pallasii (Fig. 52) has recently been found along the southwestern James Bay coast (Sims 860, 1977; SSMF), a southern range extension.

Overall, the northern coastal sites differ floristically from the richer sites such as Shiplands Island, Arnold Point and North Point. More than 100 of the taxa recorded from these three areas were not found at Longridge or Puskwuche Points (Table 1) while 31 (14 per cent) of the species at Longridge or Puskwuche Points were not found at North Point or the mouth of the Moose River. The species collected only at the southern sites include many freshwater wetland species and non-native taxa not yet introduced to inaccessible coastal sites. Introduced taxa include Bromus inermis, Festuca pratensis, Phleum pratense, Poa pratensis, Ranunculus acris, Trifolium 
hybridum, T. pratense, T. repens, Capsella bursa-pastoris, Matricaria matricarioides, Oenothera parviflora, Galeopsis tetrahit, and Plantago major. All of these and many other introduced taxa have been collected at Moosonee or Moose Factory, indicating the probable point source of the introductions downriver, although townsites further north in the Lowland share these introduced elements. Other non-native taxa, such as Taraxacum officinale and Vicia cracca, are more widespread introductions along the coast.

Many other species are found around the mouth of the Moose River but not at the other sites studied. Estuarine species include Sparganium eurycarpum, Alisma plantago-aquatica, Sagittaria latifolia, Catabrosa aquatica (Fig. 23), and Limosella aquatica (Fig. 37). Thicket and meadow species include Sphenopholis intermedia, Trisetum melicoides (Fig. 60), Conioselinum chinense (Fig. 27), Lilium philadelphicum, Allium schoenoprasum, Circaea alpina, Galium asprellum (Fig. 30), and Impatiens biflora. Shore and dune species include Spartina pectinata (Fig. 56), Arnica chamissonis ssp. foliosa (Fig. 14), and Apocynum sibiricum. Many of these are southern species reaching James Bay along the Moose and Albany Rivers.

The number of species and the variety of habitats in interior wetlands such as those around the Kinoje Lakes is considerably diminished relative to coastal, nonorganic, nonacidic habitats. Although the shores of the larger lakes and streams in that area were not sampled intensively, about two-thirds of the coastal and estuarine species were not found in the Kinoje Lakes area. Many of the more or less coastal species which do occur seem to find comparable habitats in marl beds or on stranded interior beach ridges; for example, Equisetum variegatum, Juniperus spp., Bromus ciliatus, Carex pauciflora, Juncus balticus, Tofieldia glutinosa, Parnassia palustris, Potentilla fruticosa, Lathyrus palustris, Rhinanthus crista-galli, and Pedicularis groenlandica (Fig. 42). The most commonly documented interior habitats of these species are along the open riparian slopes of the major rivers.

About 40 per cent of the species occurring in the Kinoje Lakes area were not found in coastal sites. Species more or less confined to interior wetlands tended to be acidophiles or species of calcareous fens; for example, Selaginella selaginoides, Scheuchzeria palustris, Muhlenbergia glomerata, Eriophorum tenellum, E. vaginatum ssp. spissum, E. virginicum, Eleocharis elliptica, Scirpus cespitosus, Rhynchospora alba, $R$. fusca, Carex chordorrhiza, $C$. exilis, $C$. rariflora, Eriocaulon septangulare, Juncus stygius var. americanus, Platanthera lacera (Fig. 45), Malaxis unifolia (Fig. 40), Pogonia ophioglossoides (Fig. 46), Anemone parviflora, Sarracenia purpurea, Drosera anglica, D. linearis, Ledum groenlandicum, Kalmia angustifolia, K. polifolia, Andromeda glaucophylla, Chamaedaphne calyculata, Melampyrum lineare, Pinguicula vulgaris, Utricularia cornuta, and $U$. minor.

Boreal forest elements not occurring along the coast but not uncommon in the interior included Equisetum sylvaticum, Gymnocarpium dryopteris, Pinus banksiana, Thuja occidentalis, Betula X sandbergii, Coptis groenlandica, Ranunculus lapponicus, Mitella nuda, Amelanchier bartramiana, Aralia nudicaulis, Monotropa uniflora, Gaultheria hispidula, Vaccinium myrtilloides, V. uliginosa, Trientalis borealis, Lonicera oblongifolia, L. villosa, Aster ciliolatus, and Petasites palmatus. Open-water species apparently confined to interior wetlands included Isoetes echinospora, Potamogeton natans, and Nuphar luteum ssp. variegatum. Many of these species begin to appear within $10 \mathrm{~km}$ of the coast; boreal elements are more 
common in the Moose River basin where treed fen and swamp predominate, while the open fen-bog complexes characteristic of the lower Albany River basin support the acidophiles and fen elements commonly occurring around the Kinoje Lakes.

In addition to species mentioned above with respect to estuarine and southern coastal sites, there are other southern elements in the study areas; for example, Malaxis monophylla var. brachypoda (Fig. 39), Malaxis unifolia (Fig. 40), Astragalus canadensis (Fig. 17), Ceratophyllum demersum (Fig. 24), Platanthera lacera (Fig. 45), and Pogonia ophioglossoides (Fig. 46). Predominantly western and northwestern elements in the flora of this area include Artemisia tilesii ssp. elatior (Fig. 15), Chrysanthemum arcticum ssp. polare, Androsace septentrionalis (Fig. 11), Arnica chamissonis ssp. foliosa (Fig. 14), Cicuta mackenzieana (Fig. 26), Antennaria pulcherrima (Fig. 12), A. parviflora, Eleocharis kamtschatica (Fig. 28), Erigeron lonchophyllus (Fig. 29), Juncus ensifolius (Fig. 34; not in study areas), and Pedicularis parviflora Fig. 43). Many of these are significantly disjunct species, some with St. Lawrence or Lake Superior populations.

Many well-known disjunct species occur in the southern James Bay area (Table 2). Of the 31 species treated here as significantly disjunct, four are not strictly coastal and two of these, Platanthera lacera and Malaxis monophylla var. brachypoda, should be expected between the Great Lakes to the south and their James Bay Lowland populations, as is the case with Arethusa bulbosa (Fig. 13), a species of habitats similar to Platanthera lacera. Another, Juncus ensifolius (Fig. 34), is known from three stations along the lower reaches of the Harricana and Nottaway Rivers (Dutilly and Lepage 1963) and is a long-range disjunction from its closest western population in the Cypress Hills of Alberta and southwestern Saskatchewan. The other species, Conioselinum chinense, has a northern range limit from the Hamilton Inlet of Labrador up the St. Lawrence River including the north shore and Lac St. Jean, to the Carolinian Zone of southern Ontario, and on into Wisconsin. This erroneously named endemic species of northeastern North America apparently has variable habitat requirements, from calcareous rocky coasts to serpentine cliffs to subarctic sites, and "plus rarement, dans les clairières humides et les forêts de conifères"' (Rousseau, 1974:328). Certainly in southern Ontario it seems to have become extremely rare over the last 30 years (Fig. 27). There are several stations near the mouth of the Moose River, more than $700 \mathrm{~km}$ from the closest population (Lac St. Jean area) and over $800 \mathrm{~km}$ from populations in southern Ontario.

The remainder of these lowland coastal species can be generally separated into those disjunct only from the eastern seaboard, those disjunct from eastern and western populations, and those disjunct from areas east, west, and south of the Canadian Shield. Eleven species are disjunct from eastern and western centres of distribution. All 11 species occur in the Gulf of St. Lawrence: the western stations involved are from saline prairie populations of Glaux maritima var. obtusifolia (Fig. 33), Scirpus maritimus var. paludosus (Fig. 55), S. rufus var. neogaeus, Suaeda calceoliformis (Fig. 59), Erigeron lonchophyllus (Fig. 29; also weedy near Thunder Bay), and Gentianella crinita ssp. macounii (Fig. 31; also near Thunder Bay); and from Pacific coast populations of Zostera marina (also at Churchill, Manitoba, and Eskimo Point, N.W.T.; Fig. 62), Carex mackenziei (western Hudson Bay, then Pacific and western Arctic coasts; Fig. 20), Eleocharis kamtschatica (Fig. 28), Spergularia canadensis (Fig. 57), and Polygonum fowleri (Fig. 47). Prairie populations may have been more widespread at the time of the xerothermic maximum, if assumed increased 


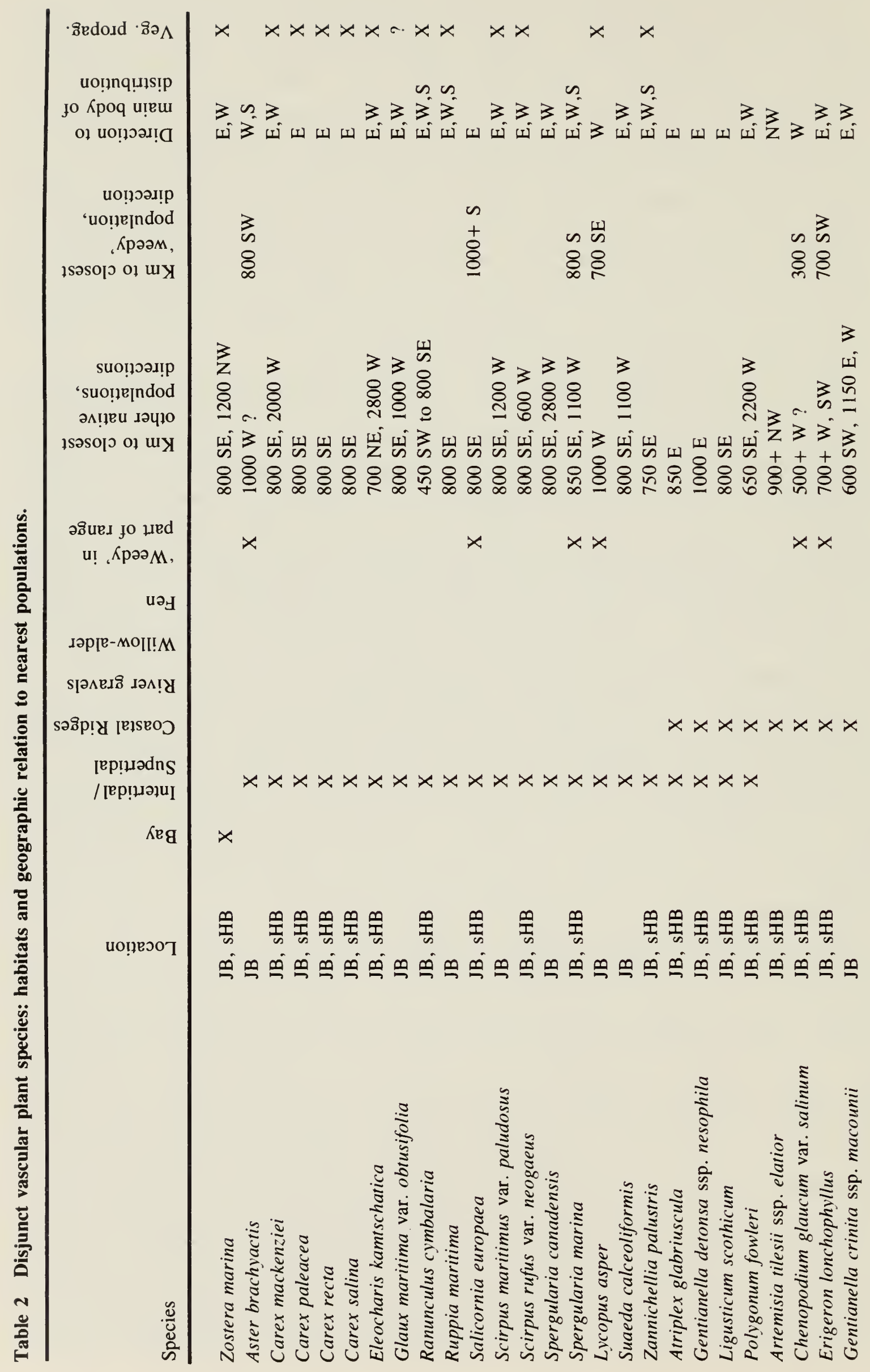




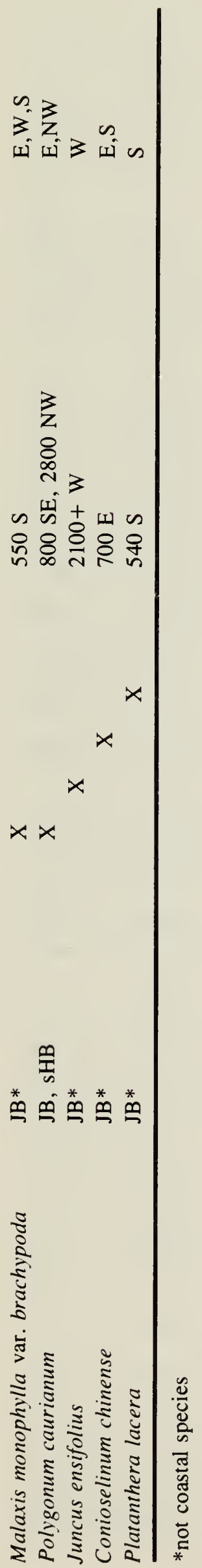


evapotranspiration resulted in more widespread saline habitats. Some of these east and west disjunctions need not have migrated from the east towards James Bay, but rather from prairie populations eastward.

Aster brachyactis (Fig. 16), Lycopus asper (Fig. 38), and Chenopodium glaucum var. salinum (Fig. 25) are examples of species known to be native in the west, but recently introduced in their eastern and southern ranges. They are apparently native along the James Bay coast. Artemisia tilesii ssp. elatior (Fig. 15) is a widespread northwestern species also occurring on Manitoba's coast, but not known from Ontario's Hudson Bay coast. It is abundant on coastal beachridges of James Bay south of Akimiski Island. It is not known anywhere in the east; the James Bay population probably derives from a northwestern centre of distribution. (Polygonum caurianum, Puccinellia lucida (Fig. 49), and Primula incana might be noted in addition to the above species but there are difficulties in the taxonomic interpretation of these species.)

Another group of lowland disjunctions, in this case involving less significant distances, are those well known to the east, west, and south of the Canadian Shield, but also recurring in James Bay. These include Ranunculus cymbalaria (Fig. 51; also abundant along southern Hudson Bay), Spergularia marina (Fig. 58; rare on James and Hudson Bays), Zannichellia palustris (Fig. 61), and Ruppia maritima (Fig. 53). Of these, only Spergularia marina is known as an erratic widespread introduction to saline habitats, such as around salt storage facilities. It has been collected only once on James Bay, by Lepage in 1953, and has not been found subsequently despite close examination by the authors of the Puskwuche Point area where it was originally collected. Inasmuch as habitat deterioration is not a factor in this case, it is possible that Lepage sampled an initial point introduction which was not a successful long-term survivor.

Scirpus americanus has been considered disjunct on James Bay (Potter, 1932). Its closest populations to those of James Bay and the Lower Albany River (Dutilly et al., 1954) were thought to be those eastward at Lac St. Jean and the St. Lawrence, and southward on the Great Lakes. However, recent collections of the species on the Engelhart River (Riley 8211, 1978; TRT) and at Onakawana (Riley, 1972; TRT) indicate that the species is not significantly disjunct.

Seven of the disjunct species discussed here are east coast species only. Some are confined to the Gulf of St. Lawrence southward: Salicornia europaea (Fig. 54), Atriplex glabriuscula (Fig. 18), and Gentianella detonsa ssp. nesophila (Fig. 32). The others extend up the Labrador coast north of Hamilton Inlet: Carex paleacea (Fig. 21), C. recta, C. salina (Dutilly et al., 1954), and Ligusticum scothicum (Fig. 36). Such differences in the northward east coast ranges of coastal species have been cited in assessing the hypothesis that such species may have once had continuous coastal distributions around all or part of the Quebec-Labrador peninsula. Many coastal species have reasonably continuous distributions at the present time, for example Carex glareosa (Fig. 19), C. subspathacea (Fig. 22), Mertensia maritima (Fig. 41), Elymus mollis (also on the upper Great Lakes), Plantago maritima (Fig. 44), and Puccinellia phryganodes (Fig. 50).

Others, such as Lathyrus maritimus ssp. pubescens (Fig. 35) and Draba incana, do not have continuous coastal distributions but are so widespread in the east that it seems possible that their present status as minorly disjunct species will diminish as more intermediate collections are made. 
The species mentioned above as disjunctions both to the east and west can also be separated in terms of their distributions on the east coast. Species confined to the Gulf of St. Lawrence and southward are Glaux maritima var. obtusifolia, Scirpus maritimus var. paludosus, S. rufus var. neogaeus, Spergularia canadensis, Suaeda calceoliformis, Erigeron lonchophyllus (Anticosti and Mingan Island area), and Gentianella crinita ssp. macounii (Bonaventure area). Species extending north of Hamilton Inlet are Zostera marina, Carex mackenziei, and Eleocharis kamtschatica, with Polygonum fowleri not reaching quite so far north as Hamilton Inlet.

\section{Discussion}

Similarities in the distributions and habitats of disjunct species in southern James Bay may reflect parallel means of postglacial dispersal. However, because this coastal habitat is atypical of the Hudson Bay Lowland as a whole, the dispersal mechanisms involved should not necessarily be considered to be those generally available to the flora of the region. The 31 species discussed here as significant disjuncts are mainly coastal, and three of the four non-coastal disjuncts are found within $10 \mathrm{~km}$ of the coast. All of the remaining 27 are species of open lowland meadow-marsh or beachridge habitats. These species are either maritime or predominantly halophytic in the major parts of their ranges, but their subarctic ranges are much more restricted than other cosmopolitan coastal species such as Honkenya peploides, Mertensia maritima, Stellaria humifusa, Potentilla anserina var. groenlandica, or Carex subspathacea.

With regard to the ability of these disjuncts to readily colonize sites, it can be noted that none is dioecious or heterostylous. This is, however, in no way exceptional for species of the region as a whole. Most of the coastal species can be considered natural colonizers and, in new or changeable habitats, the ability to colonize from a single propagule is of reproductive significance.

Ignoring anthropogenic, historically introduced populations, the closest native populations of 20 of the 27 coastal species discussed occur in the St. Lawrence Gulf or River estuary. Seven are confined to the east coast except for their James Bay or southern Hudson Bay populations. The remaining disjunctions are from the east and far west (five), from the east and prairies (three), from the east, west, and south (three), and from the east and south (one). The three species distributed across the prairies, the three species distributed widely to the east, west, and south, and other disjunct species such as Scirpus rufus, Erigeron lonchophyllus, Gentianella crinita ssp. macounii, and Lycopus asper are as likely to have derived from western (or southern) as from east coast populations, particularly in light of how little is known of the dispersal mechanisms involved. In fact, it may be as valid at this stage to suggest that some of the Gulf of St. Lawrence populations involved may have been introduced there from the west, or from the west via James Bay or southern Hudson Bay.

Eastern Canadian disjunctions of upland arctic-alpine elements and Gulf of St. Lawrence littoral species have been commented on extensively. The earliest hypothesis of in situ survival of preglacial floras in specific areas (Fernald, 1925, 1935) has largely been superseded by the concept of widespread late-glacial colonization of pseudo-arctic/alpine periglacial habitats (Rousseau, 1974) with subsequent survival of disjunct elements in edaphically or climatically suitable (non-competitive) sites (Drury, 1969; Wynne-Edwards, 1937, 1939). Recent 
Quaternary studies of weathering zones on Baffin Island (Boyer and Pheasant, 1974; Miller et al., 1977), of related zonation southward in Labrador (Ives, 1975), and of late-Wisconsin local ice caps in Newfoundland (Brookes, 1970) and the Canadian maritime provinces (Grant, 1977), suggest the necessity of reconsidering at least the length of time ice-free areas have been available locally for colonization. This suggestion has also been made on the basis of the distribution and ecology of carabid beetles in Newfoundland (Lindroth, 1963). Certainly, the possibility of coastal refugia in northeastern North America has long been considered (Dahl, 1946, 1955; Gillett, 1960; Morisset, 1971; Packer and Vitt, 1974).

Nevertheless, a better definition of the areal scope and duration of suitable periglacial post-Wisconsin corridors or ice-free areas is desirable, in order to estimate the potential role of long-range dispersal of plant species between edaphically or climatically receptive "island" areas. This problem is important in terms of lowland or halophytic disjunctions in heavily glaciated interior areas such as southern James Bay.

In 1927, Svenson published an account of Atlantic coastal halophytes and indifferent halophytes recurring in the western interior of North America, citing among his examples Spergularia marina, Glaux maritima, Salicornia europaea, Rumex maritimus, Scirpus maritimus var. paludosus, S. rufus, Zannichellia palustris, Ruppia maritima, and Ranunculus cymbalaria. He also mentioned Erigeron lonchophyllus and Aster brachyactis as members of the western halophytic flora appearing in the Gulf of St. Lawrence. He described the major factors involved: (i) major new transportation routes and salt works development; (ii) wind and birds; (iii) available alternative habitats (limestone or marl) for indifferent halophytes; (iv) migration through post-Pleistocene lakes and sea incursions; and (v) combinations of these factors.

Potter (1932) suggested that a post-Pleistocene marine connection between Hudson Bay and the St. Lawrence could explain the recurrence in southern Hudson Bay of Atlantic seaboard species such as Zannichellia palustris, Glaux maritima, Carex glareosa, Plantago maritima, Scirpus rufus, and Zostera marina, and indifferent halophytes such as Scirpus americanus. However, other species he cited are known to be more widespread than he anticipated; for example, Triglochin palustris, Juncus balticus, Potamogeton filiformis, Lathyrus maritimus (Fig. 35), Honkenya peploides, Mertensia maritima, and Bidens hyperborea. Possible causes were presented as coincident driftless areas, dispersal by various agencies (wind, animals, birds, water) and dispersal by a marine connection. He concluded that the latter hypothesis was most reasonable, on the basis of known marine fossil occurrences and the presence of raised beaches which he associated with marine rather than proglacial submergence. Similarly, LaRocque (1949) proposed a marine connection from the St. Lawrence to James Bay via Lac St. Jean, a possibility also discounted by geologists.

Porsild (1932) reported Zostera marina (Fig. 62) from James and Hudson Bays, suggesting that it be considered a relic of a milder postglacial period or an introduction by migrating birds. However, Rousseau (1974) suggested that records for this species at Cape Jones (Quebec) and in Greenland indicated the possibility of migration by way of Hudson Strait.

Boivin (1952:205) maintained that the species mentioned by Potter were either not strictly halophytic or were by then known either from coastal or interior intermediate stations: "The presence of a series of halophytes in the James Bay area has to be 
explained either by a migration around the Labrador peninsula, . . . or else one has to accept the possibility of a migration via the shores of large bodies of fresh water." Cody (1954:62) added a new obligative halophyte to Potter's list, Salicornia europaea, from Charlton Island, Chickanogahish, and Cabbage Willows Bay, all in southern James Bay, but "not known from the shoreline of Hudson Bay to the north, nor . . . known from the Labrador Coast'. The work of Dadswell (1974) on the relation between the distributions of several small crustacean and fish species, and the extent of proglacial lakes between the St. Lawrence River and James Bay, offers confirmation of the linkage of aquatic biota and habitats from south to north.

Dutilly et al. (1958) pointed out that many of the most common St. Lawrence halophytes do not occur in James Bay, as they should if James Bay and the St. Lawrence had been connected. They proposed a marine connection between Payne Bay on Ungava Bay and an area between Cape Smith and Point Wolstenholme on Hudson Bay, suggesting that more hardy and vigorous halophytes could have circumdispersed this shorter coastline during the xerothermic maximum. As Potter had mentioned earlier, however, the offshore currents along the Labrador coast would be a deterrent to such a dispersal of marsh species.

In Schofield's (1959) treatment of the salt marshes of Churchill, coastal species were segregated into geographic groups: Arctic, Eastern American, American, East-West American disjuncts, Widespread Boreal-Subarctic, and Widespread Maritime. Schofield showed that their known distributions often did not extend around the Quebec-Labrador Peninsula. The unlikeliness of such maritime species accommodating themselves to intermediary proglacial lakeshores led him to restate the case for a marine connection between James Bay and the Gulf of St. Lawrence. He noted that the continual uprising of colonizable maritime coast in the area was probably significant to the dispersal of arctic, arctic-alpine, and maritime species, and to their persistence beyond the major portions of their ranges.

It is now probable that only seven species (Carex paleacea, C. recta, $C$. salina, Salicornia europaea, Atriplex glabriuscula, Gentianella detonsa ssp. nesophila, and Ligusticum scothicum) remain as reasonably assured disjunctions between James Bay/southern Hudson Bay and the Gulf of St. Lawrence. These species, of course, may have had late-glacial western distributions. Many of the other disjunct coastal species are closer to the Gulf than to other populations, but have significant prairie or southern populations which may have been much more widespread in late-glacial or xerothermic periods.

The apparently unsuccessful introduction of Spergularia marina to southwestern James Bay (Fig. 58) may be an indication of present dispersal mechanisms introducing an additional species to the open colonizable coast. In this regard, one must consider the findings of Proctor (1968) on the long-term (340 h) retention of viable seed by Least Sandpiper and Killdeer, and his encouragement of study of the premigration ingestion of seed by shorebirds and waterfowl, and the possible premigration emptying of digestive tracts by such birds. Dispersal of plant disseminules by birds is more strongly supported circumstantially than empirically; there are opinions both supportive (Carlquist, 1974) and less than enthusiastic (Löve, 1963).

Ongoing banding-dyeing programmes with shorebirds of southwestern James Bay (Morrison, Canadian Wildlife Service, pers. comm.) have documented the large-scale migration of Hudson Bay Lowland shorebirds between the coastal migration corridor 
of James Bay and the Atlantic coast. For example, the Semipalmated Sandpiper's fall migration from southern James Bay seems to focus on the Gulf of St. Lawrence, and then southward. Their spring migration to James Bay is not as well understood but may be more of a frontal movement of birds northward across the mid-continent. However, such patterns vary for individual bird species and, as detailed migration habits are better documented, may not even circumstantially support the case of bird-assisted dispersal. For example, knowledge of the heavy fall migration from James Bay and points northward, to the Atlantic seaboard, is supportive of bird-assisted dispersal from the northwest to the southeast, but not in the opposite direction. In addition, it is assumed that such migration routes have changed postglacially in relation to changing waterbodies and shorelines; present distributions of plants could reflect former migration routes.

Ongoing modes of plant dispersal of these disjunct coastal plant species must be viewed in conjunction with the hypotheses of migration via the shores of proglacial lakes (eastward and westward) and the circumdispersal of the Quebec-Labrador peninsula. The considerable number of species at the limits of their geographic ranges, or disjunct from their major distributional centres attests to the unusual receptivity of this new and colonizable maritime coast.

Summarizing the information on lowland disjunctions:

(i) Thirty-one vascular plant species are significantly disjunct in the study area, all but one (Ranunculus cymbalaria) for more than $500 \mathrm{~km}$ (Table 2), and with others ranging up to $2100 \mathrm{~km}$ (Juncus ensifolius);

(ii) Twenty-one of the species occur in intertidal and/or supertidal marsh-meadow along the coast, ten species occur on coastal beachridges (four occur in both the above habitats), one species is marine, and the other three are not strictly coastal (one occurs on river gravels, another in willow-alder thickets, and the third in open graminoid fen);

(iii) Seven of the species are known to have closest populations only around the Gulf of St. Lawrence (unidirectional disjunctions; Carex paleacea, C. recta, $C$. salina, Salicornia europaea, Atriplex glabriuscula, Gentianella detonsa ssp. nesophila, Lisgisticum scothicum). Ten of the species are known to be disjunct from Gulf of St. Lawrence populations (usually the closest) and from western populations (bidirectional disjunctions). The remaining 14 species are disjunct from native populations in the near west only ( $3 \mathrm{sp}$.), the east, south, and west $(5 \mathrm{sp}$.), the far west only (Juncus ensifolius), the northwest (Artemisia tilesii), the south (Platanthera lacera), the east and south (Conioselinum chinense), as well as the east and northwest (Polygonum caurianum);

(iv) The three species disjunct from the near west only (Aster brachyactis, Lycopus asper, Chenopodium glaucum var. salinum) and three others (Salicornia europaea, Spergularia marina, Erigeron lonchophyllus) are known introductions to disturbed habitats in southeastern Canada;

(v) Of the 31 disjunct species, 5 belong to innately complex taxonomic groups such as Erigeron Section Trimorphaea (E. lonchophyllus), Carex Section Cryptocarpae (C. salina), Polygonum Section Avicularia (P. caurianum), and Gentianella Section Eublephis ( $G$. detonsa, $G$. crinita);

(vi) There is no apparent correlation between the direction of closest native population and the species' habitat on James Bay; 
(vii) These disjunct distributions are the result of postglacial migration from the east, west, and/or south, not necessarily from the currently closest populations, by means of various dispersal mechanisms including migration via shores of proglacial lakes, circumdispersal around the Quebec-Labrador peninsula during the hypsithermal period, and ongoing modes of dispersal, such as migrating birds.

\section{Acknowledgements}

The field studies reported here extended from 1972 to 1976, and have been possible only with the assistance of several government agencies. Access to the Kinoje Lakes area was made possible by J.K. Jeglum of the Canadian Forestry Service (Fisheries and Environment Canada), A.N. Boissonneau and S. Palabekiroglus of the Ontario Centre for Remote Sensing (Ontario Ministry of Natural Resources), and D.W. Cowell of the Lands Directorate (Fisheries and Environment Canada). Access and field support at North Point and Longridge Point were generously provided by R.I.G. Morrison and R.K. Ross of the Canadian Wildlife Service (Fisheries and Environment Canada). Support of work on Shipsands Island and Puskwuche Point, and access to OMNR plant collections was provided by the Ontario Ministry of Natural Resources: R.O. Stanfield (Policy Research), D. Burton (Forest Research), and P. Prevett (Moosonee District) were particularly helpful.

We express our appreciation to R.A. Sims (CFS), W.A. Glooschenko (Geology Section, Canada Centre for Inland Waters), G. Tessier (CWS), R.D. Simpson (CWS), P.F. Maycock and W.J. Crins (Erindale College, University of Toronto), and J.K. Morton (Biology Department, University of Waterloo), for access to plant collections and field data.

G.W. Argus (National Museum of Natural Sciences) assisted in the identification of Salix spp., and P.W. Ball (Erindale College, University of Toronto) in the determination of Carex spp. We acknowledge the permission of the curators of the herbaria from which specimen data were retrieved for mapping (CAN, DAO, TRT, SSMF).

We greatly appreciate the assistance of J.R. Ritchie, P.F. Maycock, and others in reviewing preliminary manuscripts.

\section{Literature Cited}

ANDREWS, J.T

1968 The pattern and interpretation of restrained, post-glacial and residual rebound in the area of Hudson Bay. Geological Survey of Canada, Paper 68-53:49-62.

1969 Present and postglacial rates of uplift for glaciated northern and eastern North America derived from postglacial uplift curves. Canadian Journal of Earth Sciences 7:703-715.

BALDWIN, W.K.W.

1953 Plants from two small island habitats in James Bay. National Museum of Canada, Bulletin $128: 154-167$ 
BARNEBY, R.C.

1964 Atlas of North American Astragalus. Pts. 1 \& 2. Memoirs of the New York Botanical Garden 13:1-1188.

BASSETT, I.J.

1973 The plantains of Canada. Canada Dept. of Agriculture, Research Branch, Monograph $7: 1-46$.

BASSETT, I.J. and C.W. CROMPTON

1978 The genus Suaeda (Chenopodiaceae) in Canada. Canadian Journal of Botany 56:581-591.

BOIVIN, B

1952 The distribution of Arnica wilsonii Rydb. and its significance. Rhodora 54:200-205.

1966-67 Énumération des plantes du Canada. Provancheria 6. Mémoires de l'Herbier Louis-Marie, Université Laval, Quebec. (Extrait du Naturaliste Canadien.)

BOYER, S.J. and D.R. PHEASANT

1974 Delimitation of weathering zones in the fiord area of eastern Baffin Island, Canada. Geological Society of America Bulletin 85:805-810.

BROOKES, I.A.

1970 New evidence for an independent Wisconsin-age ice cap over Newfoundland. Canadian Journal of Earth Sciences 7:1374-1382.

CARLQUIST, S.

1974 Island biology. New York, Columbia University Press. 660 pp.

CHAPMAN, L.F. and M.K. THOMAS

1968 The climate of northern Ontario. Canada Dept. of Transport, Meteorological Branch, Climatological Studies 6:1-58.

CODY, W.J.

1954 Salicornia europaea in the James Bay region. Rhodora 56:61-62.

COOMBS, D.B

1954 The physiographic subdivisions of the Hudson Bay Lowlands south of 60 degrees North. Canada Dept. of Mines and Technical Surveys, Geographical Bulletin 6:1-16.

COWELL, D.W., J.K. JEGLUM, and J.C. MERRIMAN

1978 Preservation of seasonal frost in peatlands, Kinoje Lakes, southern Hudson Bay Lowland. Edmonton, 3rd International Conference on Permafrost, 1978, vol. 1, pp. $453-459$.

DADSWELL, M.J.

1974 Distribution, ecology and postglacial dispersal of certain crustaceans and fishes in eastern North America. National Museums of Canada, Publications in Zoology 11:1-110.

DAHL, E.

1946 On different types of unglaciated areas during the ice ages and their significance to phytogeography. New Phytologist 45:225-242.

1955 Biogeographic and geological indications of unglaciated areas in Scandinavia during the glacial ages. Geological Society of America Bulletin 66:1499-1519. 
DALLA TORRE, K.W. von

1958 Register zu de Dalla Torre et Harms, Genera Siphonogamarum. Weinheim, H.R. Engelmann (J. Cramer). 568 pp.

DORE, W.G.

1967 Canadian milk-vetch (Astragalus canadensis). Trail and Landscape 1:84-89.

DRURY, W.H.

1969 Plant persistence in the Gulf of St. Lawrence. In Greenidge, K.N.H. ed., Essays in plant geography and ecology. Halifax, Nova Scotia Museum, pp. 105-148.

DUTILLY, A. and E. LEPAGE

1952 Exploration sommaire de la rivière Harricana. Catholic University of America, Contribution of the Arctic Institute 3F. $39 \mathrm{pp}$.

1963 Contribution à la flore du versant sud de la baie James, Québec-Ontario. Catholic University of America, Contribution of the Arctic Institute 12F. 199 pp.

DUTILLY, A., E. LEPAGE, and M. DUMAN

1954 Contribution à la flore du versant occidental de la baie James, Ontario. Catholic University of America, Contribution of the Arctic Institute 5F. 144 pp.

1958 Contribution à la flore des îles (T.N.O.) et du versant oriental (Qué.) de la baie James. Catholic University of America, Contribution of the Arctic Institute 9F. 199 pp.

FERNALD, M.L.

1925 Persistence of plants in unglaciated areas of boreal America. Memoirs of the Gray Herbarium of Harvard University $2: 239-342$.

1935 Critical plants of the upper Great Lakes region of Ontario and Michigan. Rhodora 37: 197-222.

1950 Gray's manual of botany. 8th ed. New York, American Book Co. 1632 pp.

GILLETT, J.M.

1958 Checklist of plants of the Ottawa district. Ottawa, Canada Dept. of Agriculture, Botany and Plant Pathology Division. 89 pp.

1960 The flora of the vicinity of the Mereweather Crater, Northern Labrador. Canadian Field-Naturalist $74: 8-27$.

1963 The Gentians of Canada, Alaska and Greenland. Canada Dept. of Agriculture, Research Branch, Publication 1180:1-99.

GLEASON, H.A. and A. CRONQUIST

1963 Manual of vascular plants of northeastern United States and adjacent Canada. New York, Van Nostrand. 810 pp.

GLOOSCHENKO, W.A.

1978 Above-ground biomass of vascular plants in a subarctic James Bay salt marsh. Canadian Field-Naturalist 92:30-37.

GRANT, D.R.

1977 Glacial style and ice limits, the Quatemary stratigraphic record and changes of land and ocean levels in the Atlantic provinces, Canada. Géographie Physique et Quaternaire 31:247-260. 
HENDERSON, N.C.

1962 A taxonomic revision of the genus Lycopus (Labiatae). American Midland Naturalist $68: 95-138$

HULTÉN, E.

1958 The amphi-Atlantic plants and their phytogeographical connections. Stockholm, Almqvist \& Wiksell. 340 pp.

1962 The circumpolar plants. Vol. 1. Stockholm, Almqvist \& Wiksell. 275 pp.

1968 Flora of Alaska and neighbouring territories; a manual of the vascular plants. Stanford, Stanford University Press. 1008 pp.

1971 The circumpolar plants. Vol. 2. Stockholm, Almqvist \& Wiksell. 463 pp.

HUNTER, G.T.

1970 Post-glacial uplift at Fort Albany, James Bay. Canadian Journal of Earth Sciences $7: 547-548$.

HUSTICH, I.

1955 Forest botanical notes from the Moose River area, Canada. Acta Geographica 13(12):1-50.

1957 On the phytogeography of the subarctic Hudson Bay Lowland. Acta Geographica 16(1): $1-47$

IVES, J.D.

1975 Delimitation of surface weathering zones in eastern Baffin Island, northern Labrador and Arctic Norway: a discussion. Geological Society of America Bulletin 86:1096-1100.

JEGLUM, J.K., A.N. BOISSONNEAU, and V.F. HAAVISTO

1974 Toward a wetland classification for Ontario. Canadian Forestry Service, Sault Ste. Marie, Ontario, Information Report 0-X-215. 54 pp.

KINDLE, E.M

1923 Geology of a portion of the northern part of Moose River basin, Ontario. Geological Survey of Canada, Summary Report for 1923, Part C, pp. 21-41.

LAROCQUE, A.

1949 Post-Pleistocene connection between James Bay and the Gulf of Saint Lawrence. Geological Society of America Bulletin 60:363-379.

LEPAGE, E. and W.K.W. BALDWIN

1959 Checklist of vascular plants. In Baldwin, W.K.W., ed., Botanical excursion to the boreal forest region in northern Quebec and Ontario. Ottawa, National Museum of Canada, pp. $30-114$.

LINDROTH, C.H

1963 The fauna history of Newfoundland illustrated by carabid beetles. Opuscula Entomologica Supplementum 23:1-96.

LÖVE, D.

1963 Dispersal and survival of plants. In Löve, A. and D. Löve, eds., Atlantic biota and their history. New York, Macmillan, pp. 189-205.

1975 The native orchids of the United States and Canada, excluding Florida. New York, New York Botanical Garden. 361 pp. 
MARIE-VICTORIN, Fr.

1964 Flore laurentienne. 2. éd rev. par E. Rouleau. Montréal, Presses de l'Université de Montréal. $925 \mathrm{pp}$.

McKAY, S.M. and M.D. ARTHUR

1975 Vegetation survey of Shipsands Island and Puskwuche Point, southwestern James Bay. Ontario Ministry of Natural Resources, Policy Research Branch, Research Report. MS.

MILLER, M.G.H., J.T. ANDREWS, and S.K. SHORT

1977 The last interglacial-glacial cycle, Clyde foreland, Baffin Island, N.W.T.: stratigraphy, biostratigraphy and chronology. Canadian Journal of Earth Sciences 14:2824-2857.

MOBBERLEY, D.G.

1956 Taxonomy and distribution of the genus Spartina. Iowa State College Journal of Science $30: 471-574$.

MORISSET, $P$.

1971 Endemism in the vascular plants of the Gulf of St. Lawrence. Naturaliste Canadien 98: 167-177.

PACKER, J.G. and D.H. VITT

1974 Mountain Park: a plant refugium in the Canadian Rocky Mountains. Canadian Journal of Botany 52: 1393-1409.

PIELOU, E.C. and R.D. ROUTLEDGE

1976 Salt marsh vegetation: latitudinal gradients in zonation patterns. Oecologia 24:311-321.

PORSILD, A.E.

1932 Notes on the occurrence of Zostera and Zannichellia in Arctic North America. Rhodora $34: 90-94$.

1964 Illustrated flora of the Canadian Arctic archipelago. 2nd ed. rev. National Museum of Canada, Bulletin 146:1-218.

1966 Contributions to the flora of southwestern Yukon Territory. National Museum of Canada, Bulletin 216:1-86.

POTTER, D.

1932 Botanical evidence for a post-Pleistocene marine connection between Hudson Bay and the St.

Lawrence basin. Rhodora 34:69-89, 101-112.

PROCTOR, V.W.

1968 Long-distance dispersal of seeds by retention in digestive tract of birds. Science $160: 321-322$.

REDFIELD, A.C.

1972 Development of a New England salt marsh. Ecological Monographs 42:201-237.

REPENTIGNY, L.-G.

1978 Extension d'aire: Malaxis monophyllos var. brachypoda (Gray) F. Morris. Naturaliste Canadien 105:117-118.

RILEY, J.L. and C. MOORE

1973 Preliminary vegetation survey of Shipsands Island Waterfowl Sanctuary. Ontario Ministry of Natural Resources, Forest Research Branch, File Report 5-73. MS. 
ROLAND, A.E. and E.C. SMITH

1969 The flora of Nova Scotia. Pt. II. Dicotyledons. Proceedings of the Nova Scotian Institute of Science 26:277-746.

ROUSSEAU, C.

1974 Géographie floristique de Québec-Labrador. Travaux et Documents du Centre d'Études Nordiques 7. Québec, Presses de l'Université Laval. 799 pp.

SANFORD, B.V., A.W. NORRIS, and H.H. BOSTOCK

1968 Geology of the Hudson Bay Lowlands. Geological Survey of Canada, Paper 67-60:1-118.

SCHOFIELD, W.B.

1959 The salt marsh vegetation of Churchill, Manitoba, and its phytogeographic implications. National Museum of Canada, Bulletin 160:107-132.

SCOGGAN, H.J.

1957 Flora of Manitoba. National Museum of Canada, Bulletin 140:1-619.

SIMS, R.A., J.L. RILEY, and J.K. JEGLUM

1979 Vegetation, flora and vegetation ecology of the Hudson Bay Lowland-a literature review and annotated bibliography. Canadian Forestry Service, Sault Ste. Marie, Ontario, Information Report 0-X-297.177 pp.

SØRENSEN, T.

1953 A revision of the Greenland species of Puccinellia Parl., with contributions to our knowledge of the Arctic Puccinellia flora in general. Meddelelser om Gronland 136(3): 1-179.

SVENSON, H.K.

1927 Studies of interior distribution of maritime plants. 1. Effects of post-Pleistocene marine submergence in eastern North America. Rhodora 29:41-48, 57-72, 87-93, 105-114.

THIEN, L.B. and B.G. MARCKS

1972 The floral biology of Arethusa bulbosa, Calopogon tuberosus and Pogonia ophioglossoides (Orchidaceae). Canadian Journal of Botany 50:2319-2325.

VERDOORN, F., ed.

1938 Manual of Pteridology. The Hague, Nijhoff. 640 pp.

WEBBER, P.J. and J.W. RICHARDSON

1970 Post-glacial uplift and age at Cape Henrietta Maria, southeastern Hudson Bay, Canada. Canadian Journal of Earth Sciences 7:313-325.

WILSON, W.J.

1903 Reconnaissance surveys of four rivers southwest of James Bay. Geological Survey of Canada, Summary Report for 1902, pp. 220-241.

WYNNE-EDWARDS, V.C.

1937 Isolated arctic-alpine floras in eastern North America: a discussion of their glacial and recent history. Transactions of the Royal Society of Canada, 3rd ser., vol. 31, sect. 5:33-58.

1939 Some factors in the isolation of rare alpine plants. Transactions of the Royal Society of Canada, 3rd ser., vol. 33, sect. 5:35-42.

ZENKERT, C.A.

1934 The flora of the Niagara Frontier region. Bulletin of the Buffalo Society of Natural Sciences $16: 1-328$ 


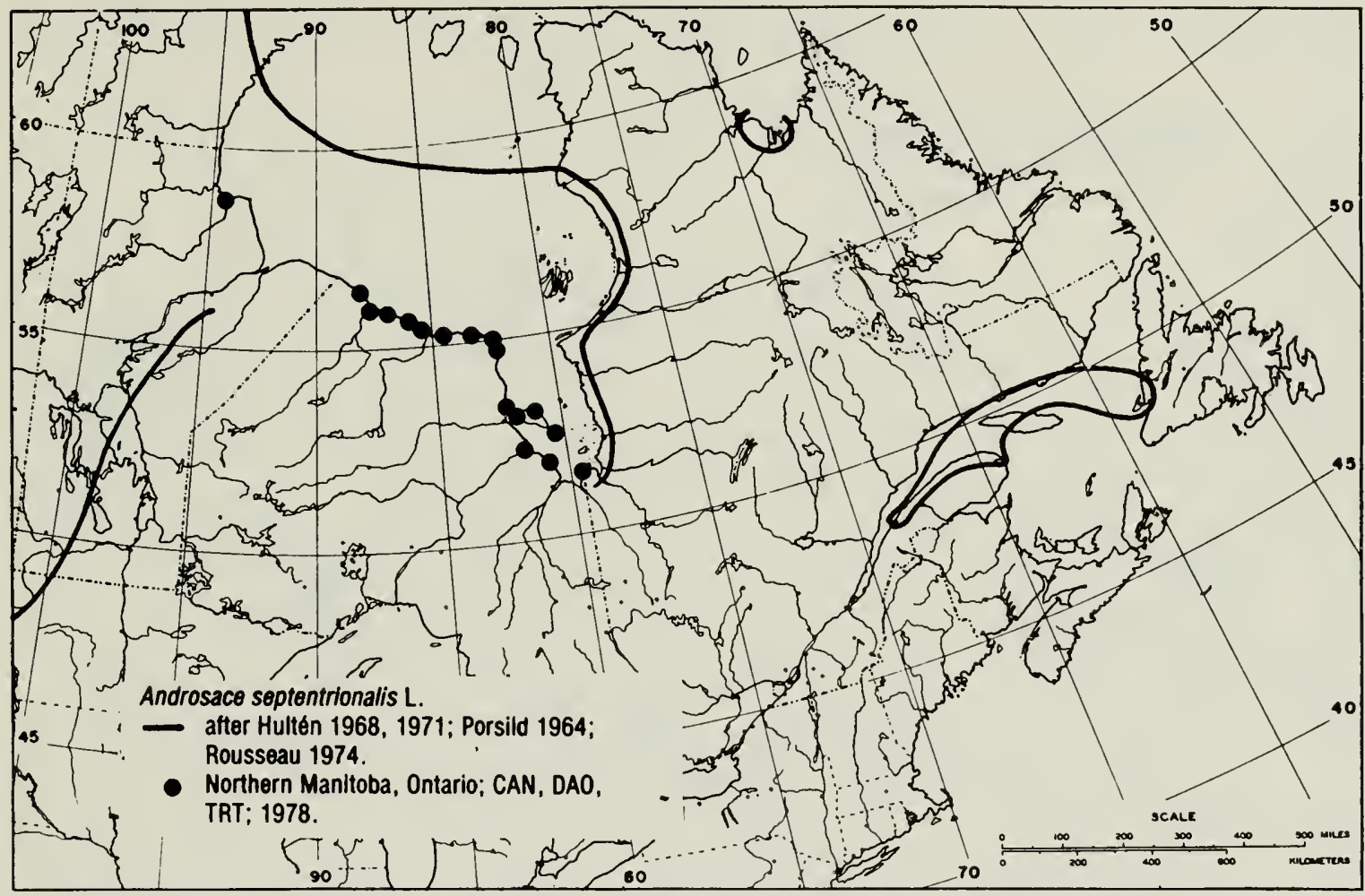

Fig. 11 Androsace septentrionalis. Northeastern North American distribution.

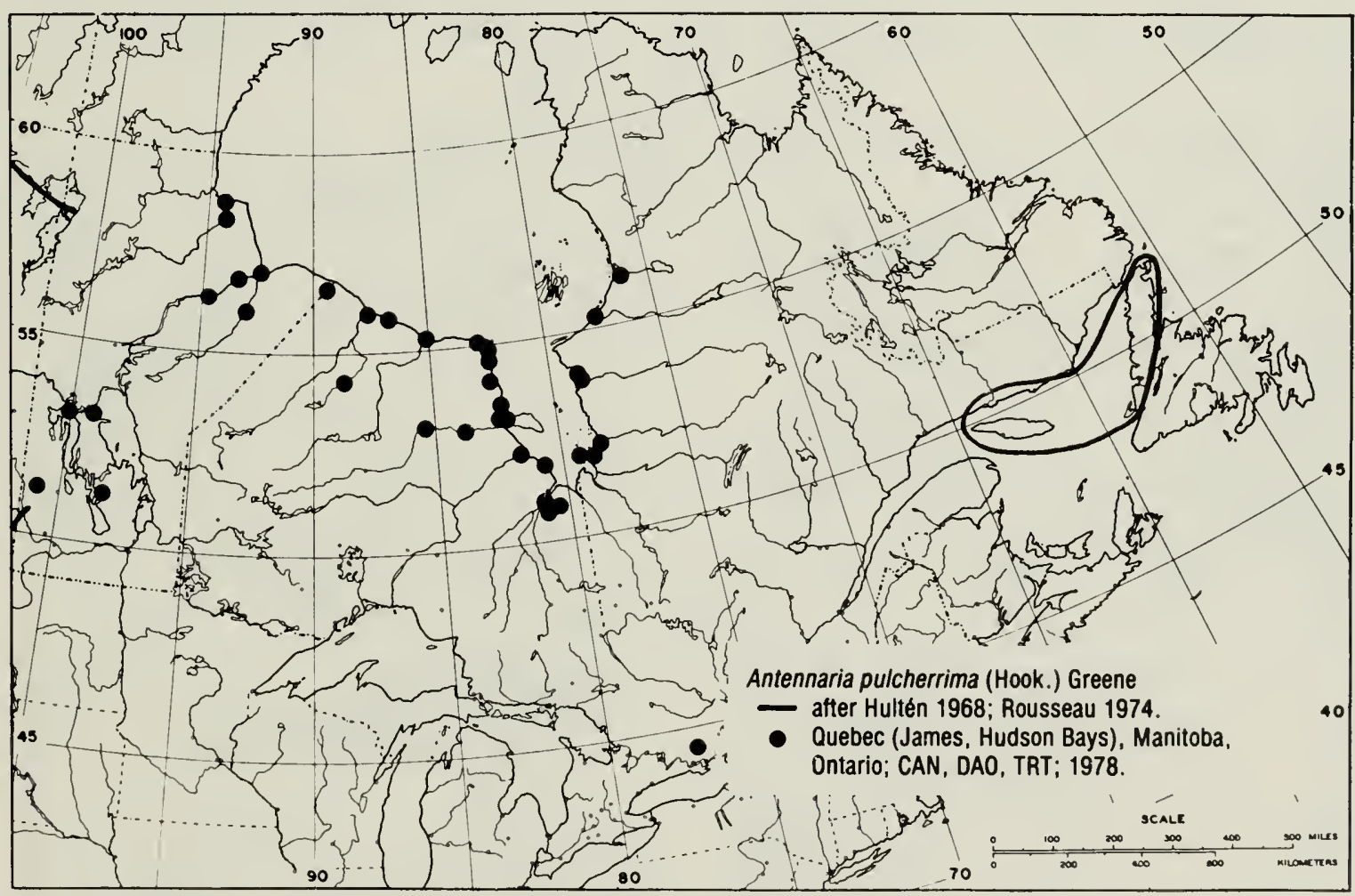

Fig. 12 Antennaria pulcherrima. Northeastern North American distribution. 


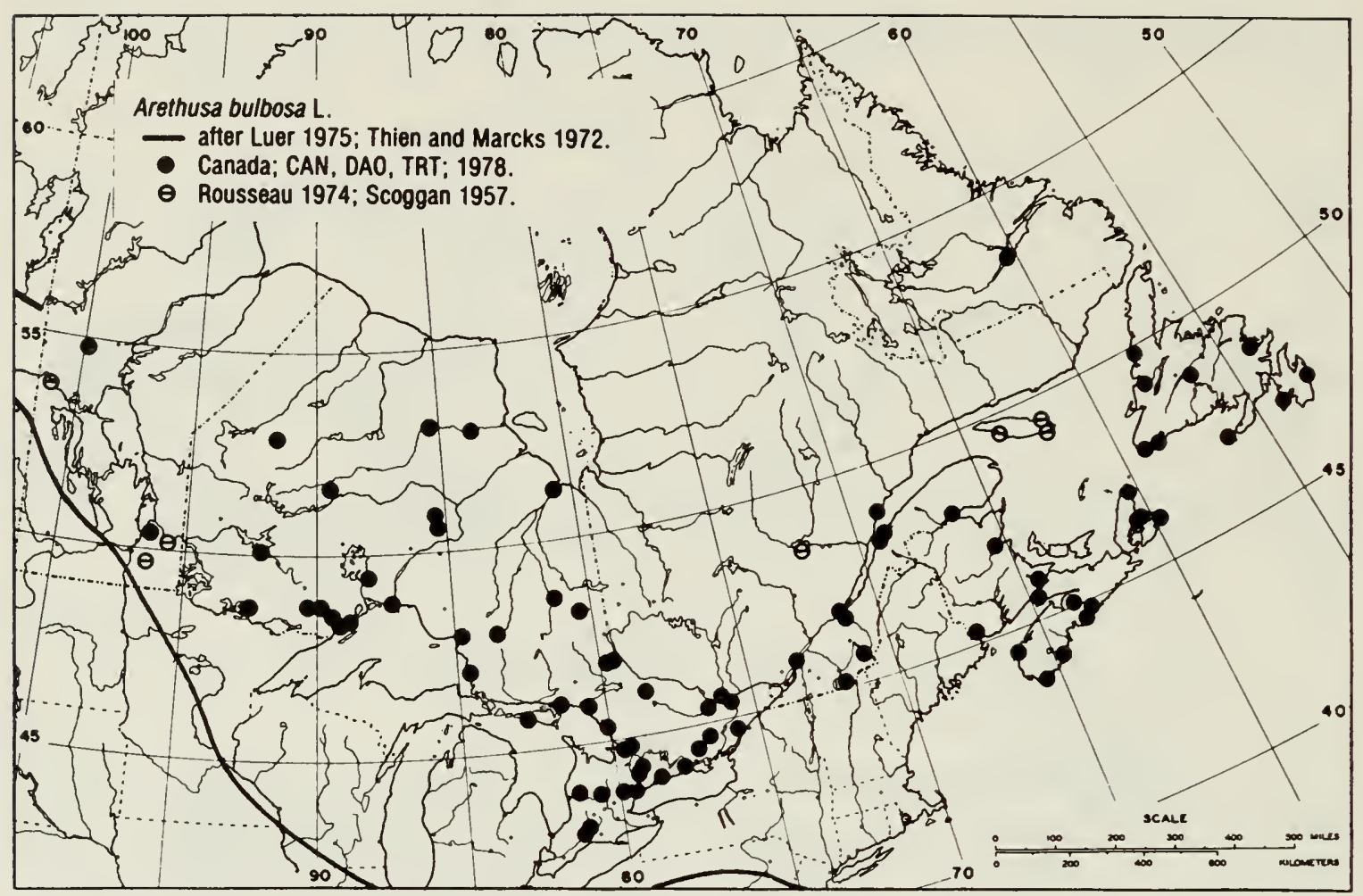

Fig. 13 Arethusa bulbosa. Northeastern North American distribution.

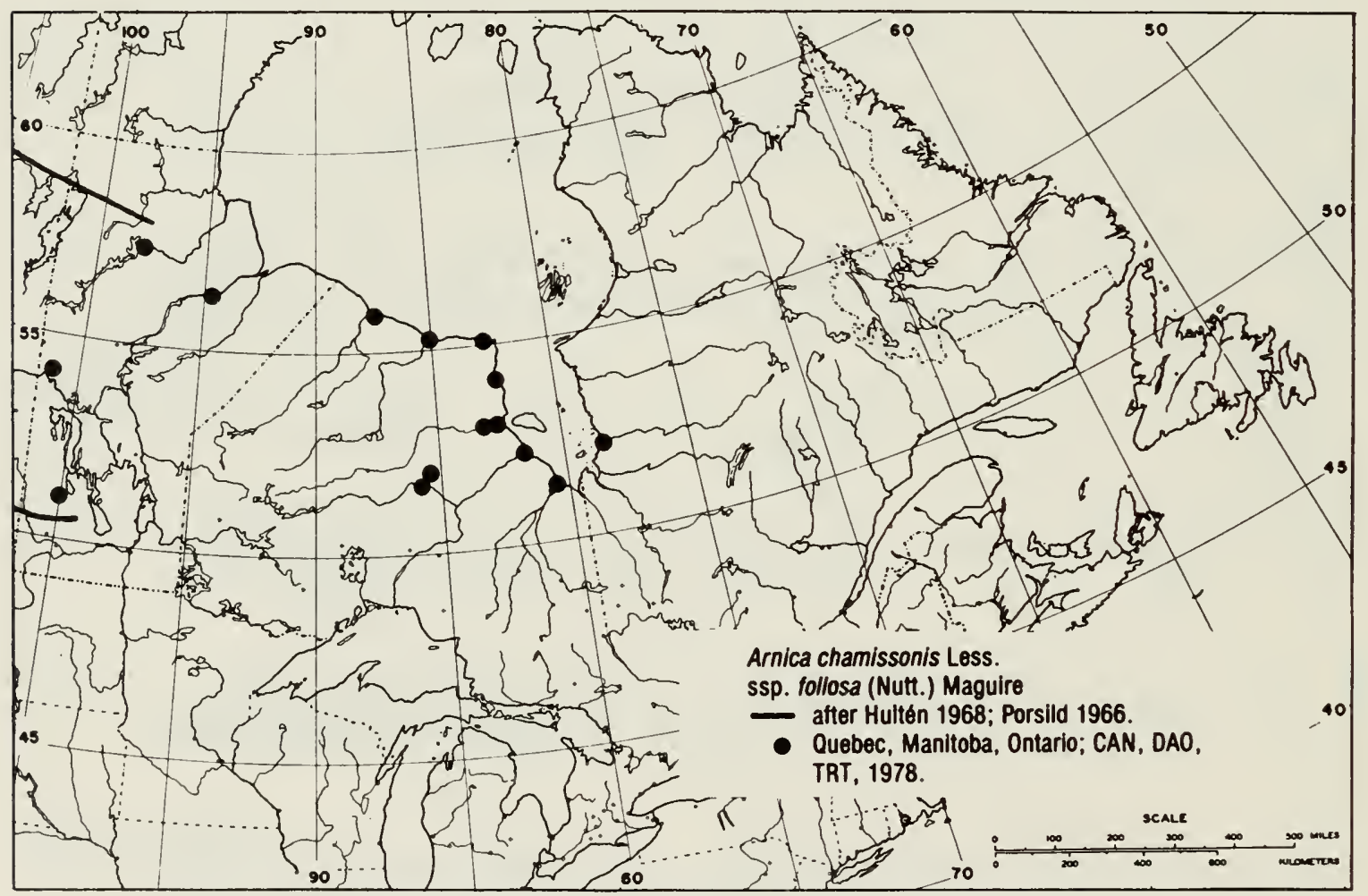

Fig. 14 Arnica chamissonis ssp. foliosa. Northeastern North American distribution. 


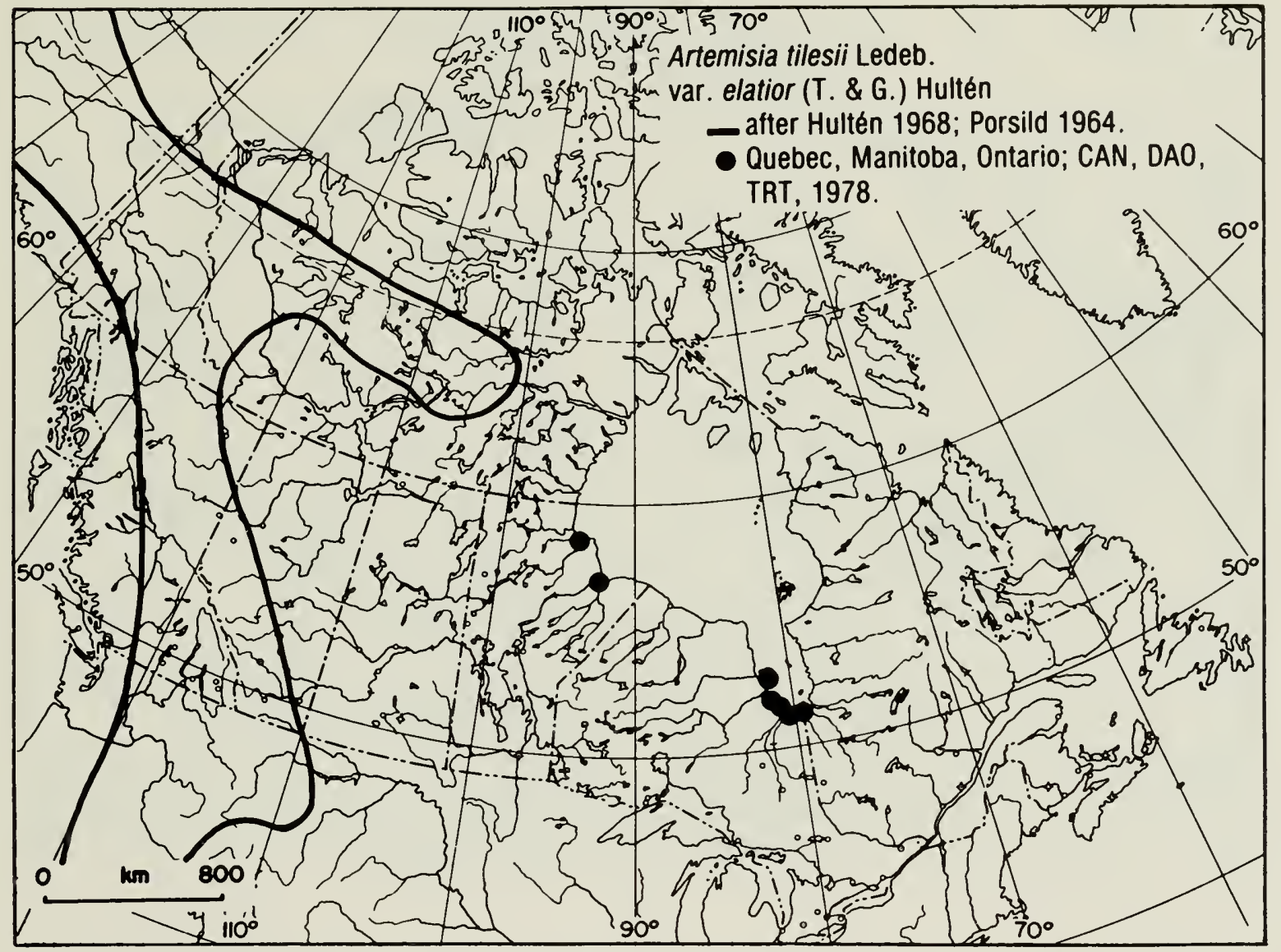

Fig. 15 Artemisia tilesii ssp. elatior. North American distribution.

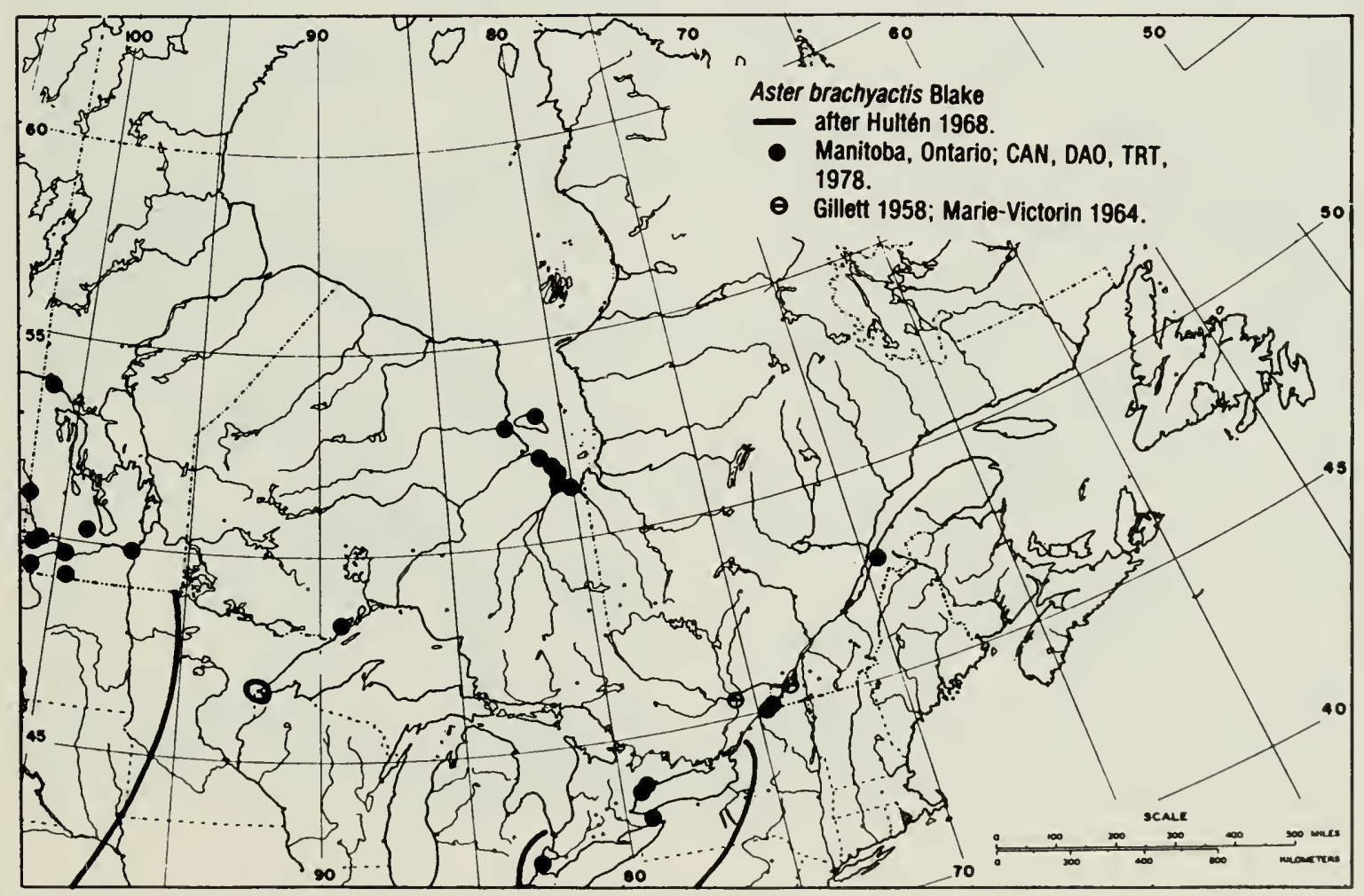

Fig. 16 Aster brachyactis. Northeastern North American distribution. 


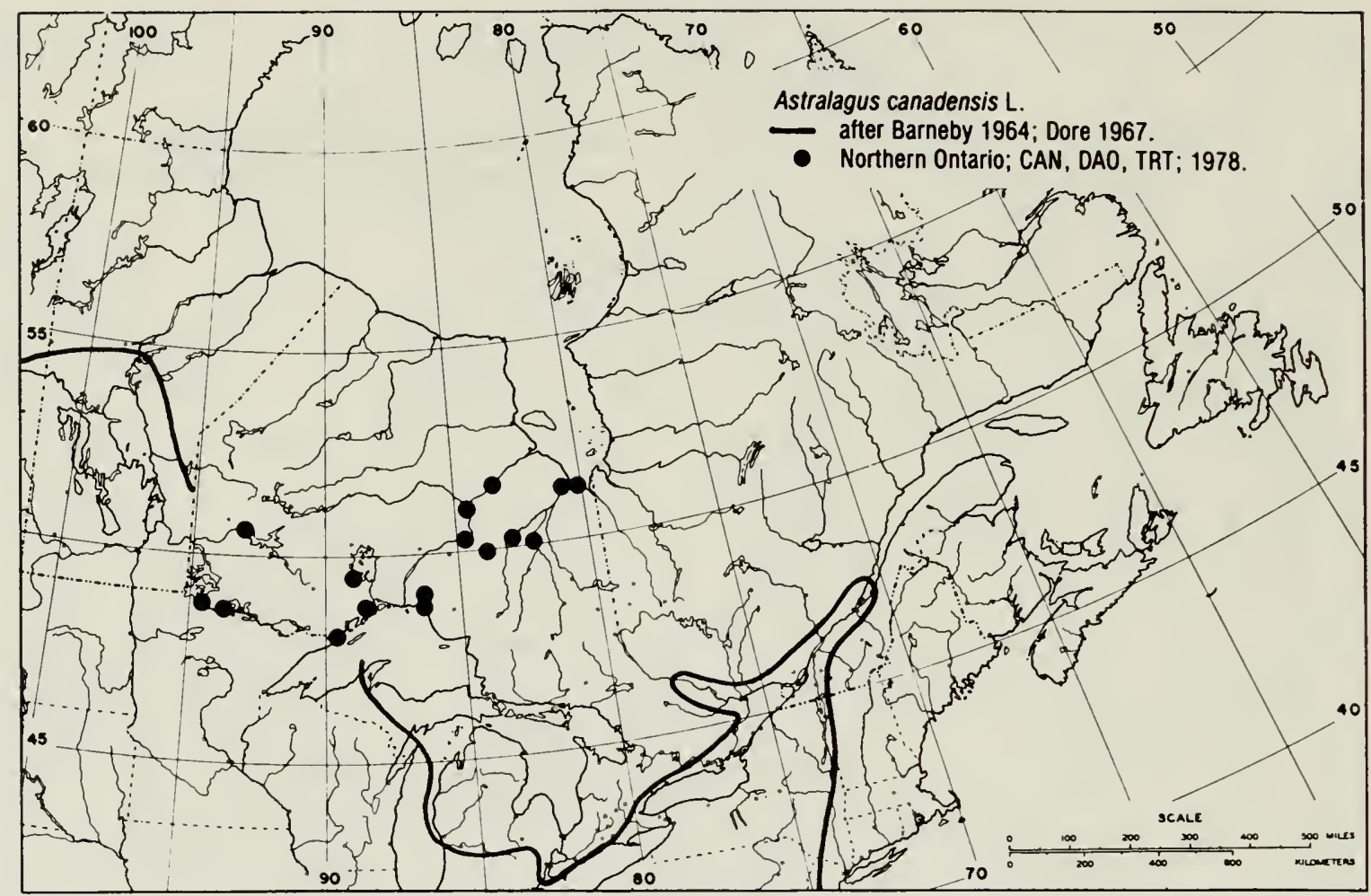

Fig. 17 Astragalus canadensis. Northeastern North American distribution.

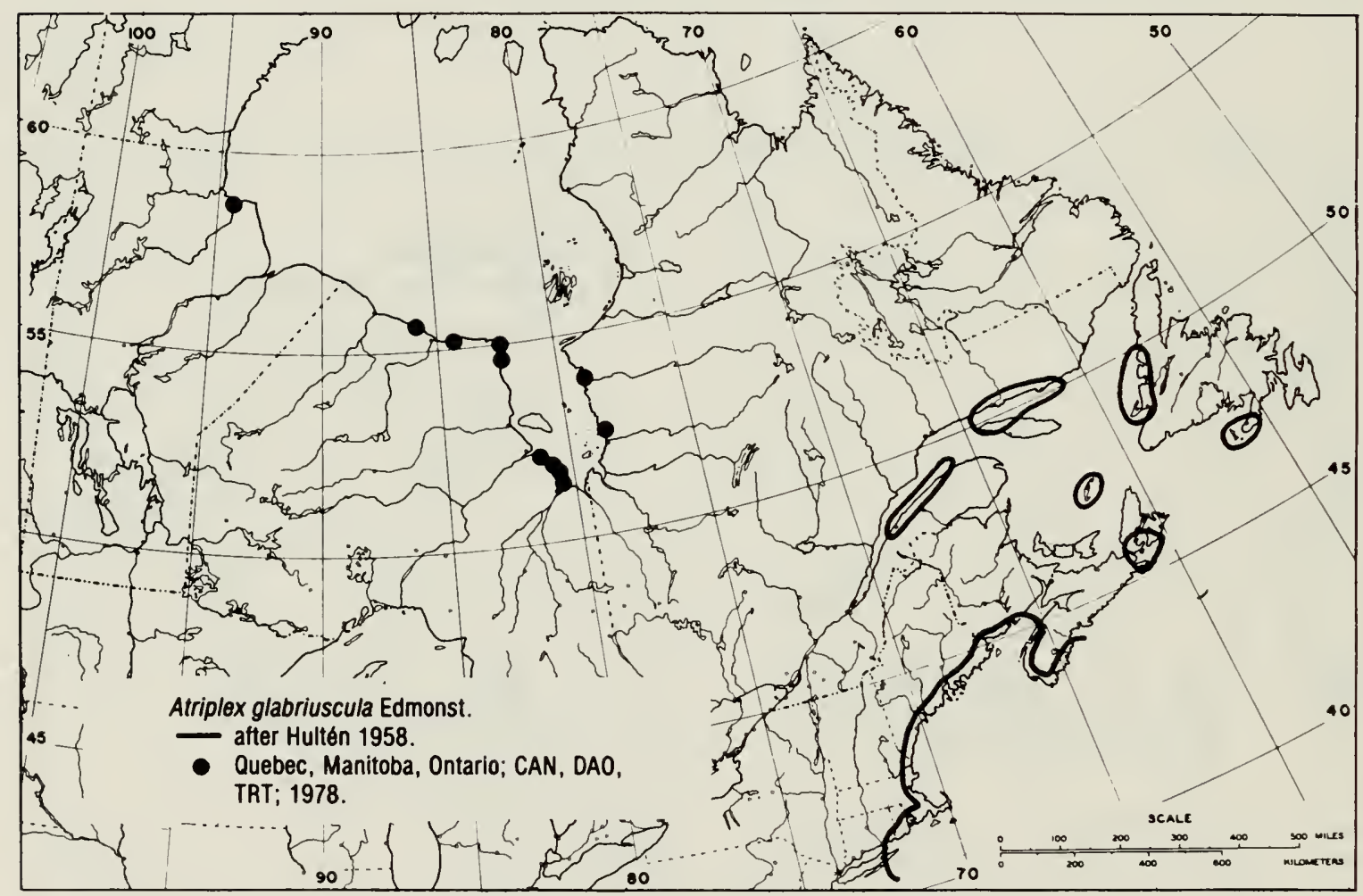

Fig. 18 Atriplex glabriuscula. Northeastern North American distribution. 


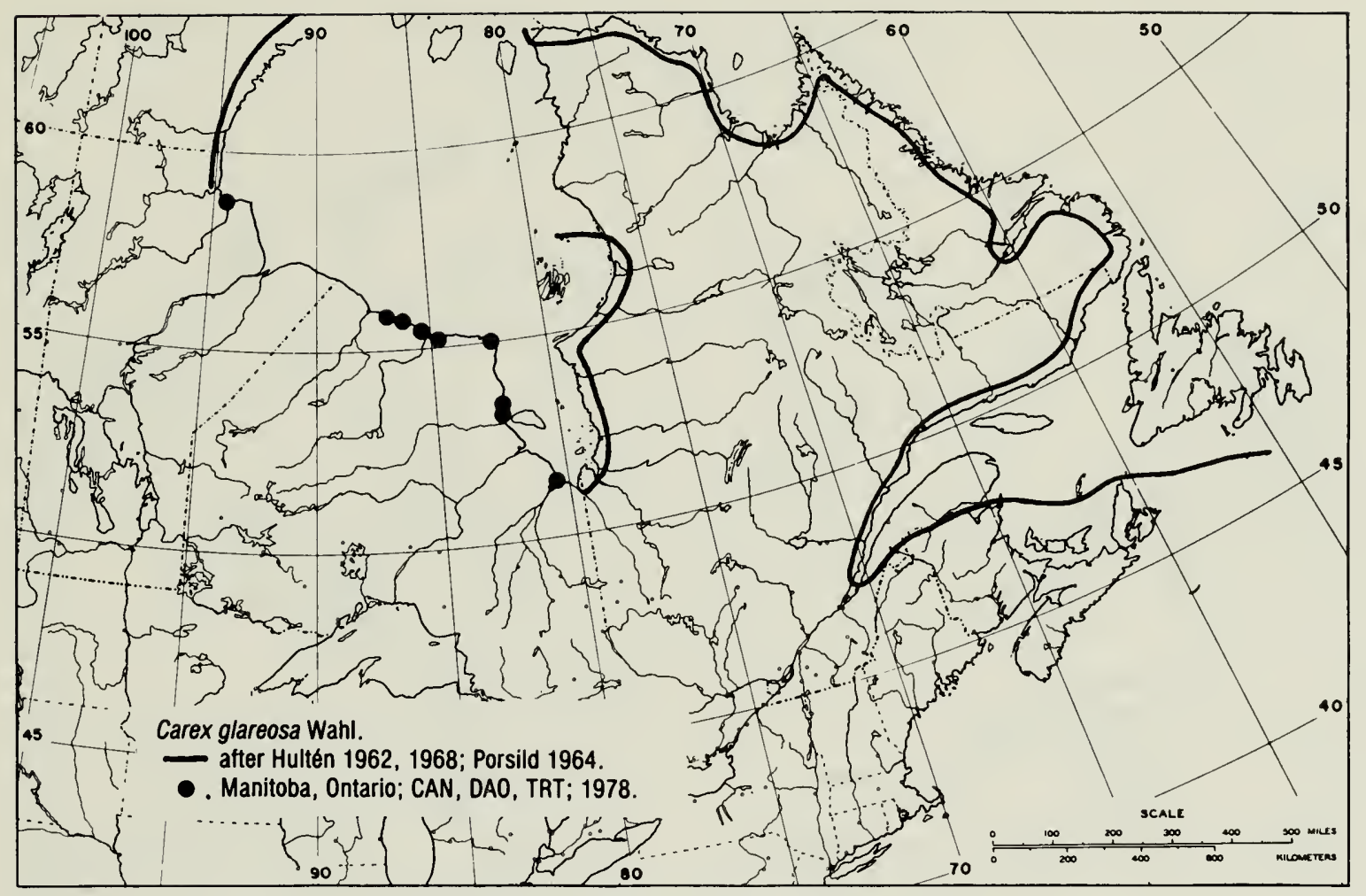

Fig. 19 Carex glareosa. Northeastern North American distribution.

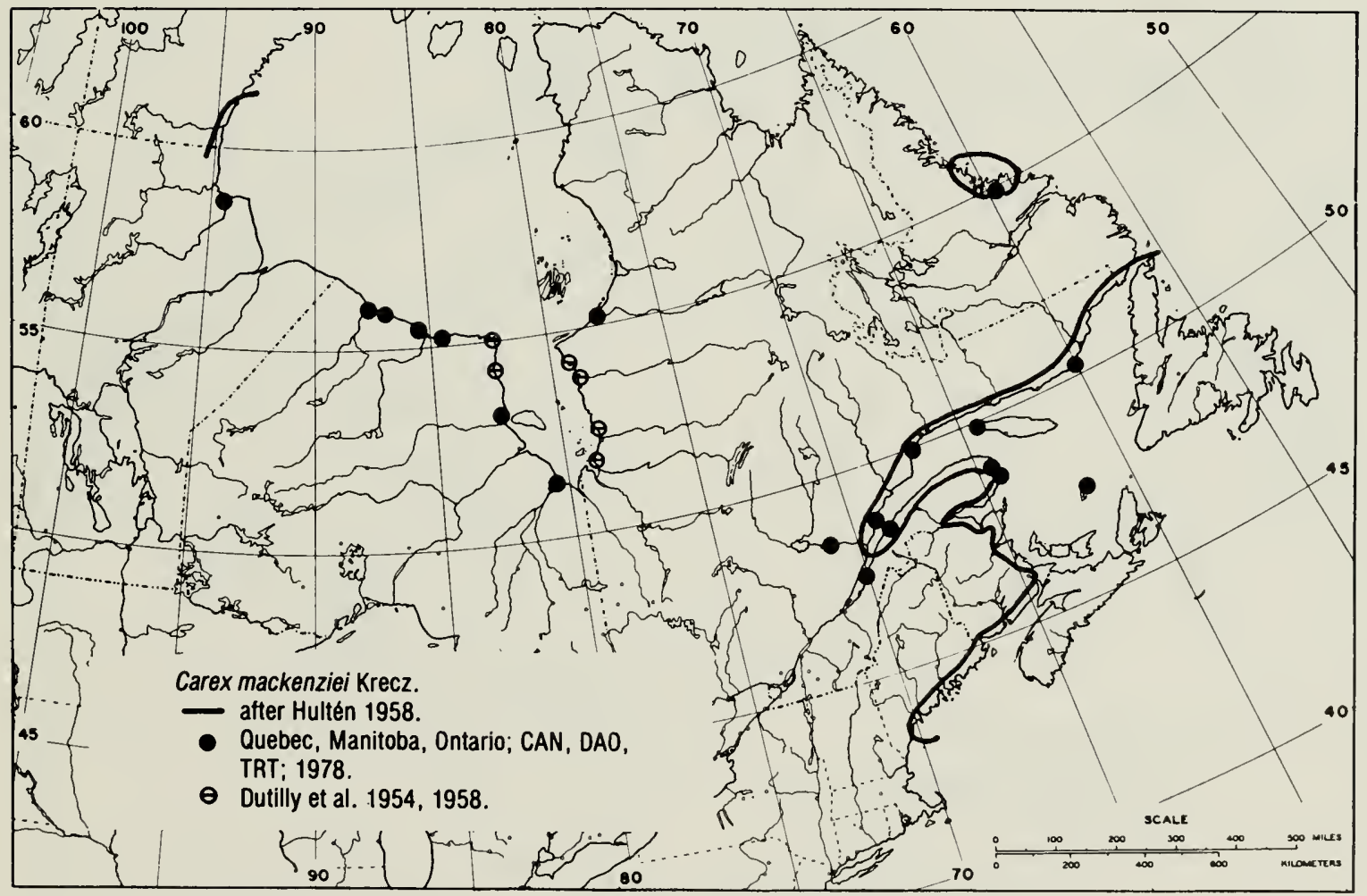

Fig. 20 Carex mackenziei. Northeastern North American distribution. 


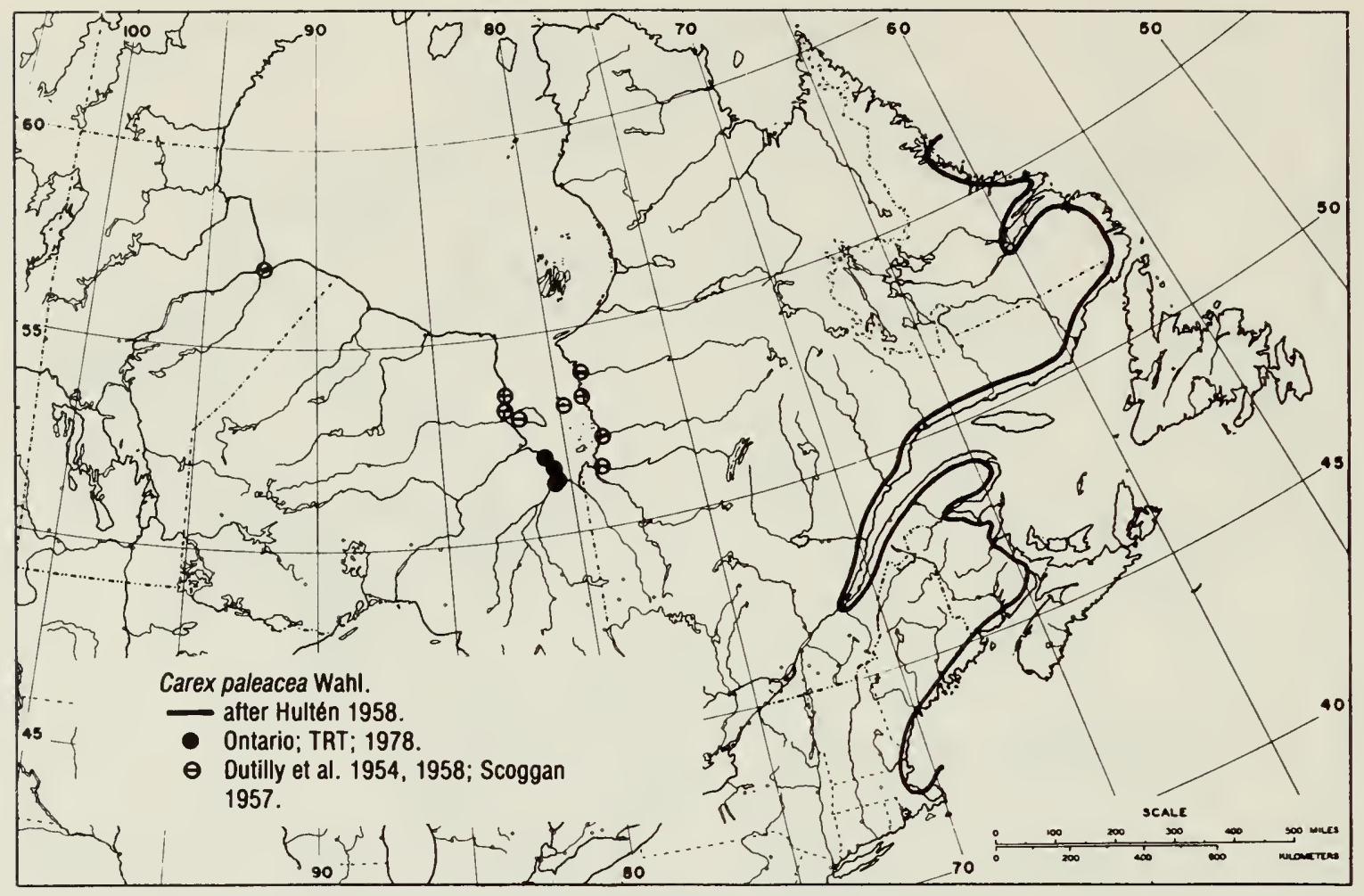

Fig. 21 Carex paleacea. Northeastern North American distribution.

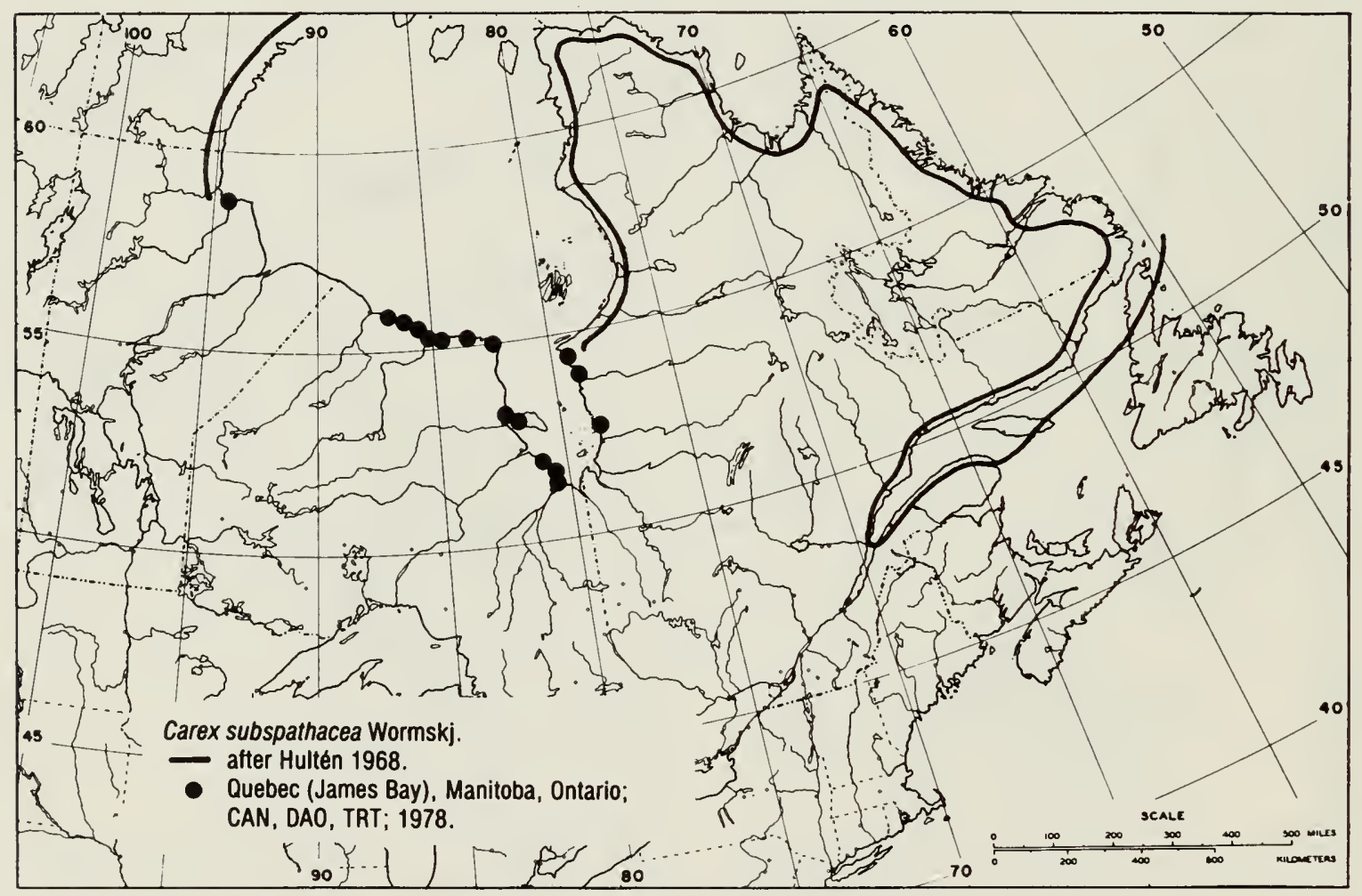

Fig. 22 Carex subspathacea. Northeastern North American distribution. 


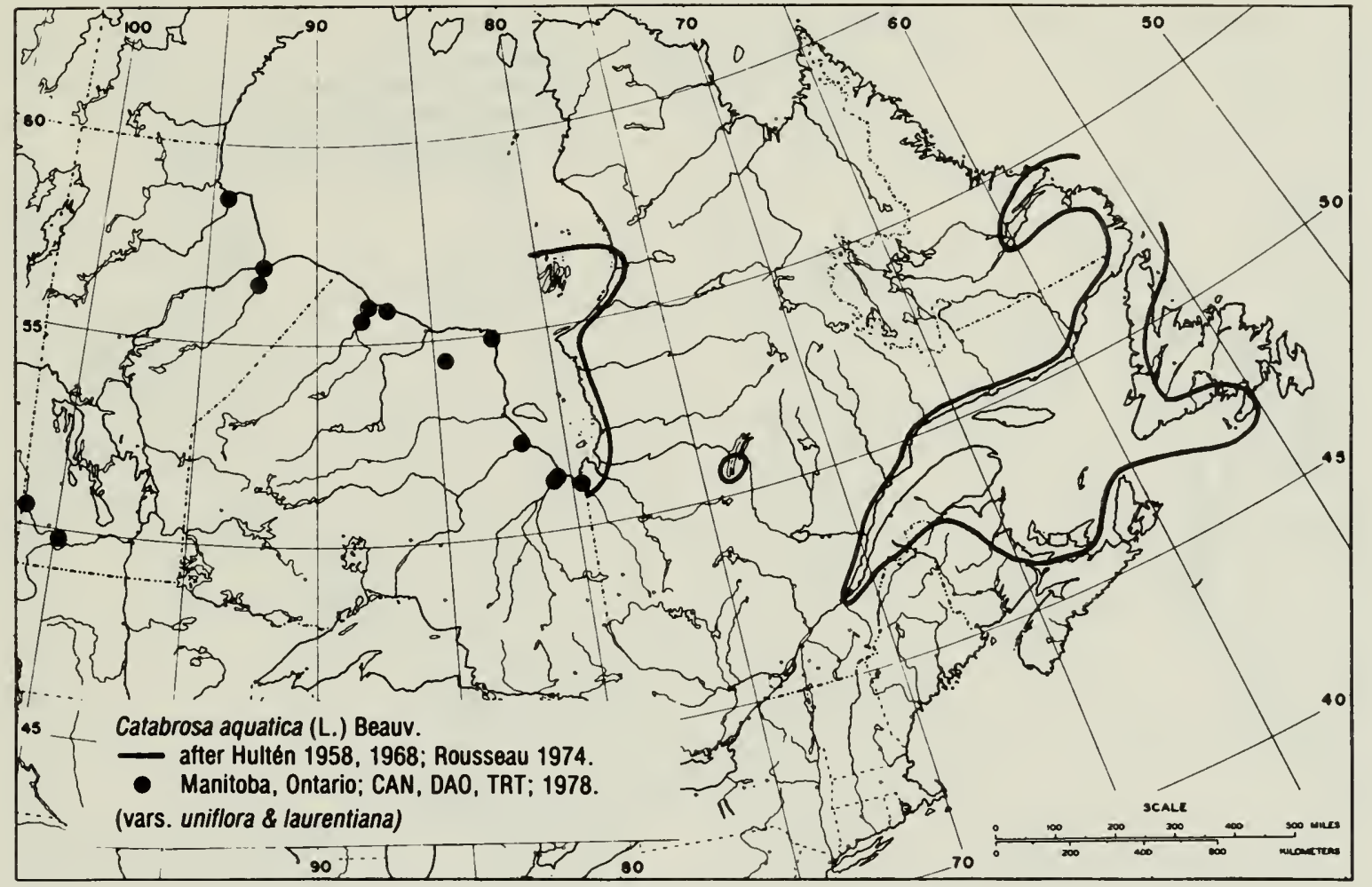

Fig. 23 Catabrosa aquatica. Northeastern North American distribution.

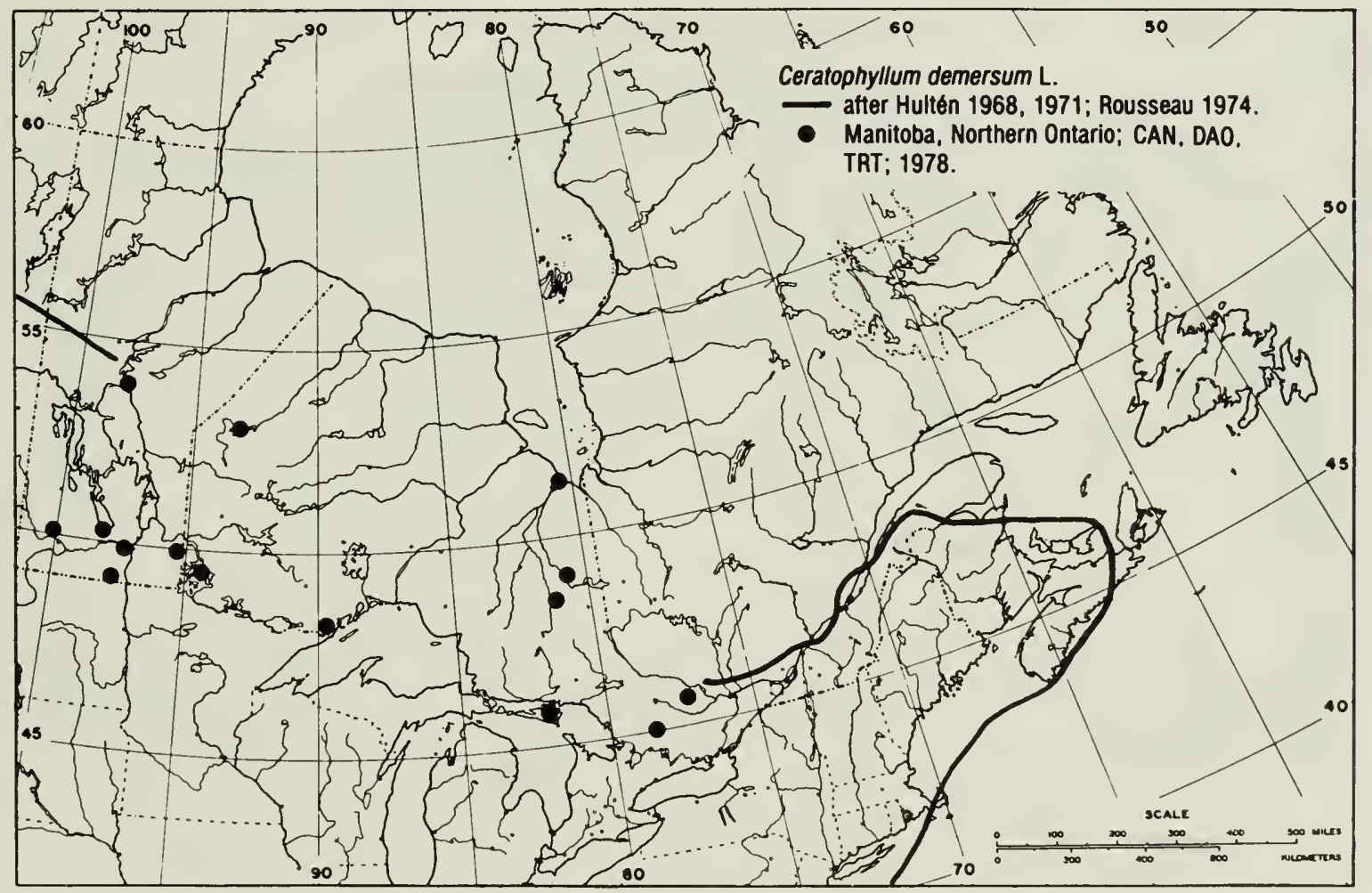

Fig. 24 Ceratophyllum demersum. Northeastern North American distribution. 


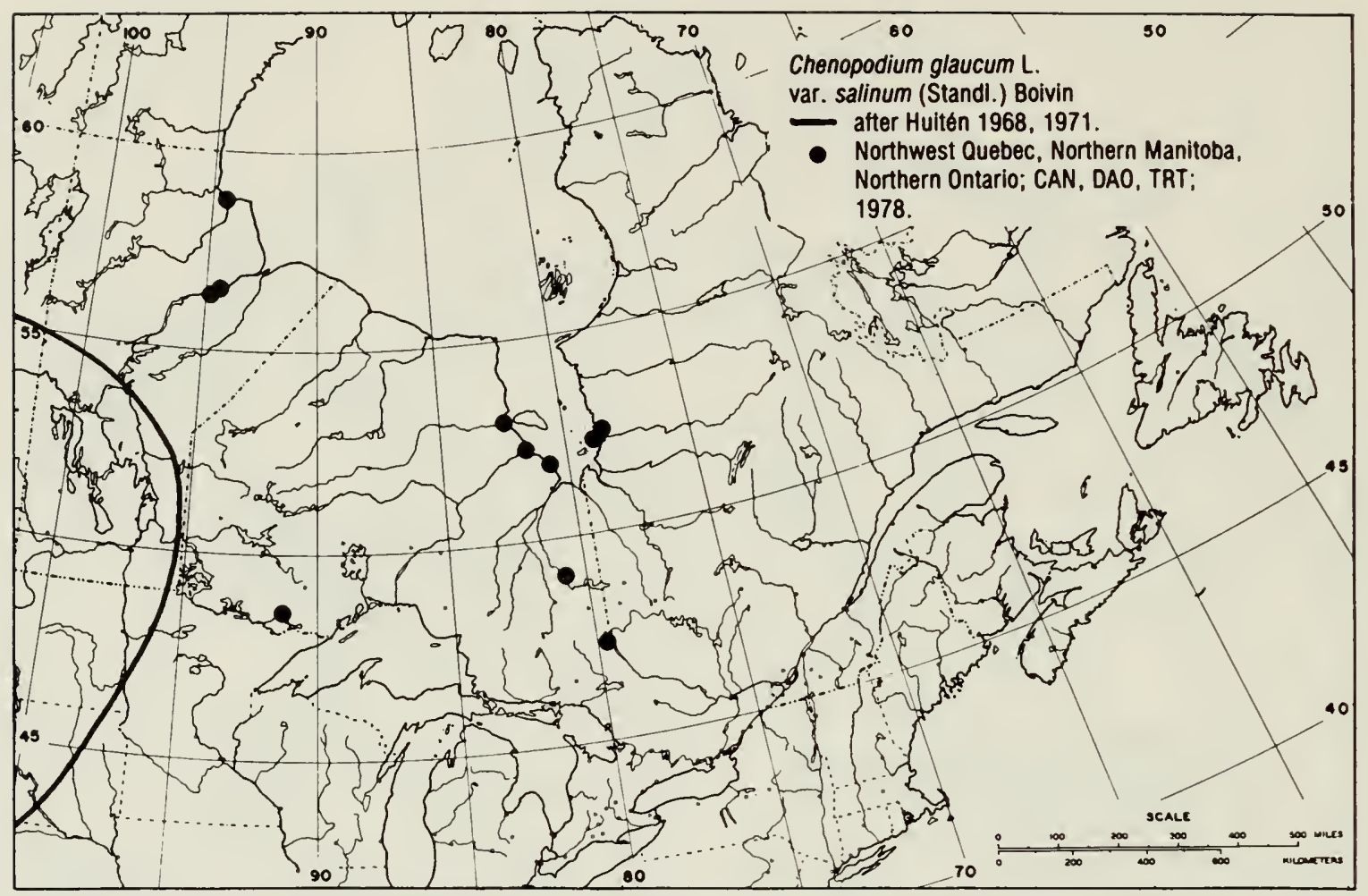

Fig. 25 Chenopodium glaucum var. salinum. Northeastern North American distribution.

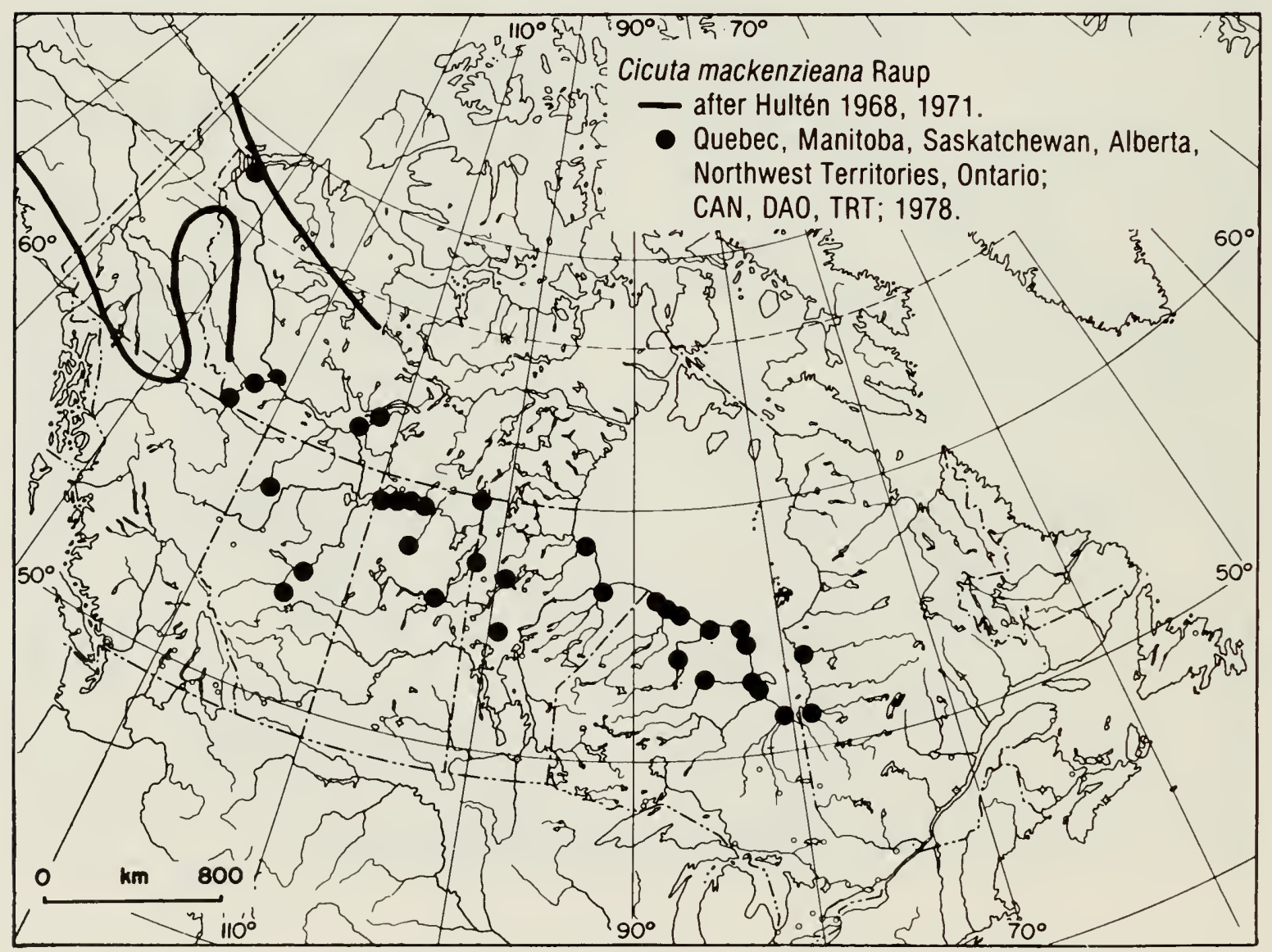

Fig. 26 Cicuta mackenzieana. North American distribution. 


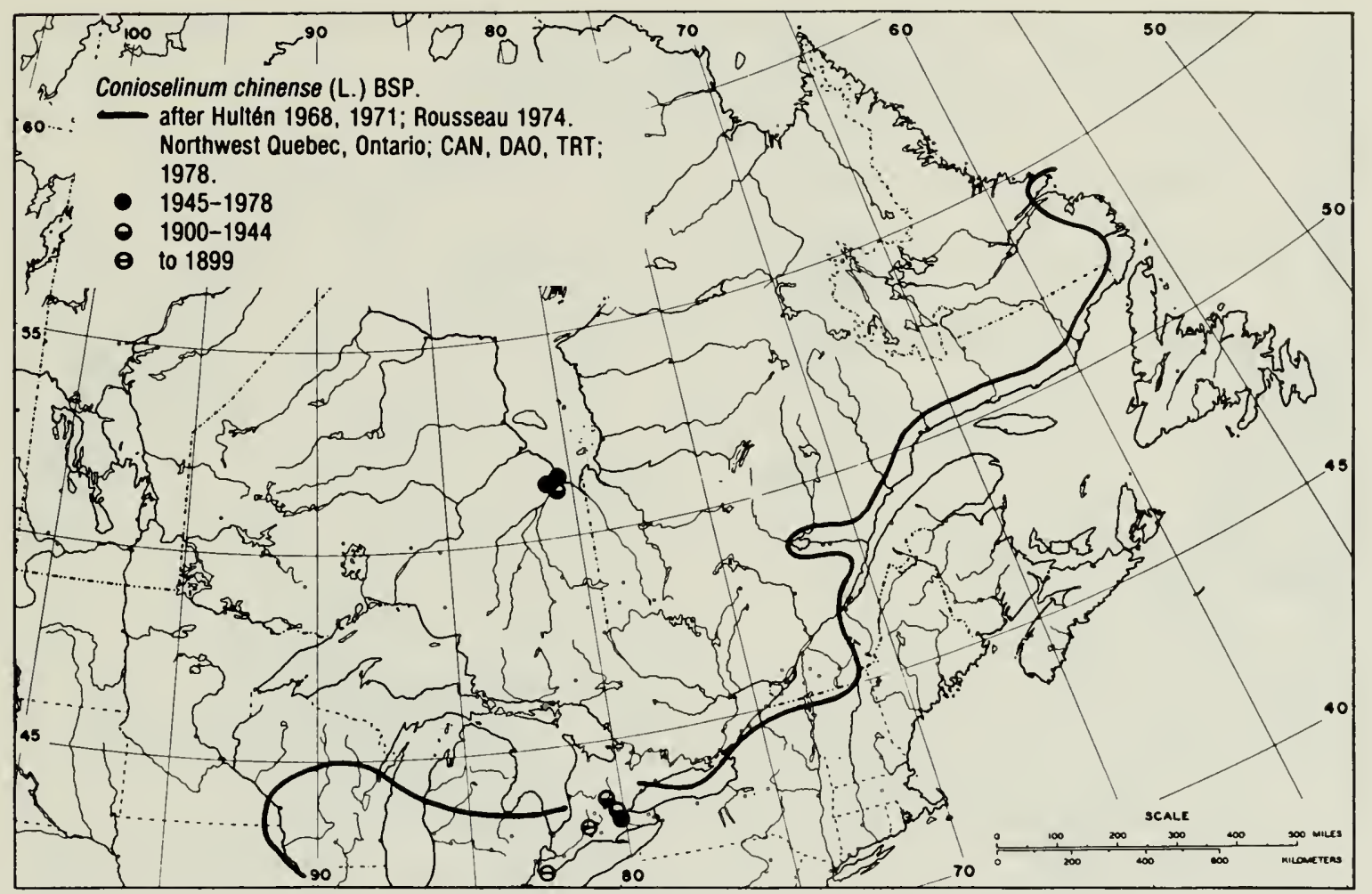

Fig. 27 Conioselinum chinense. Northeastern North American distribution.

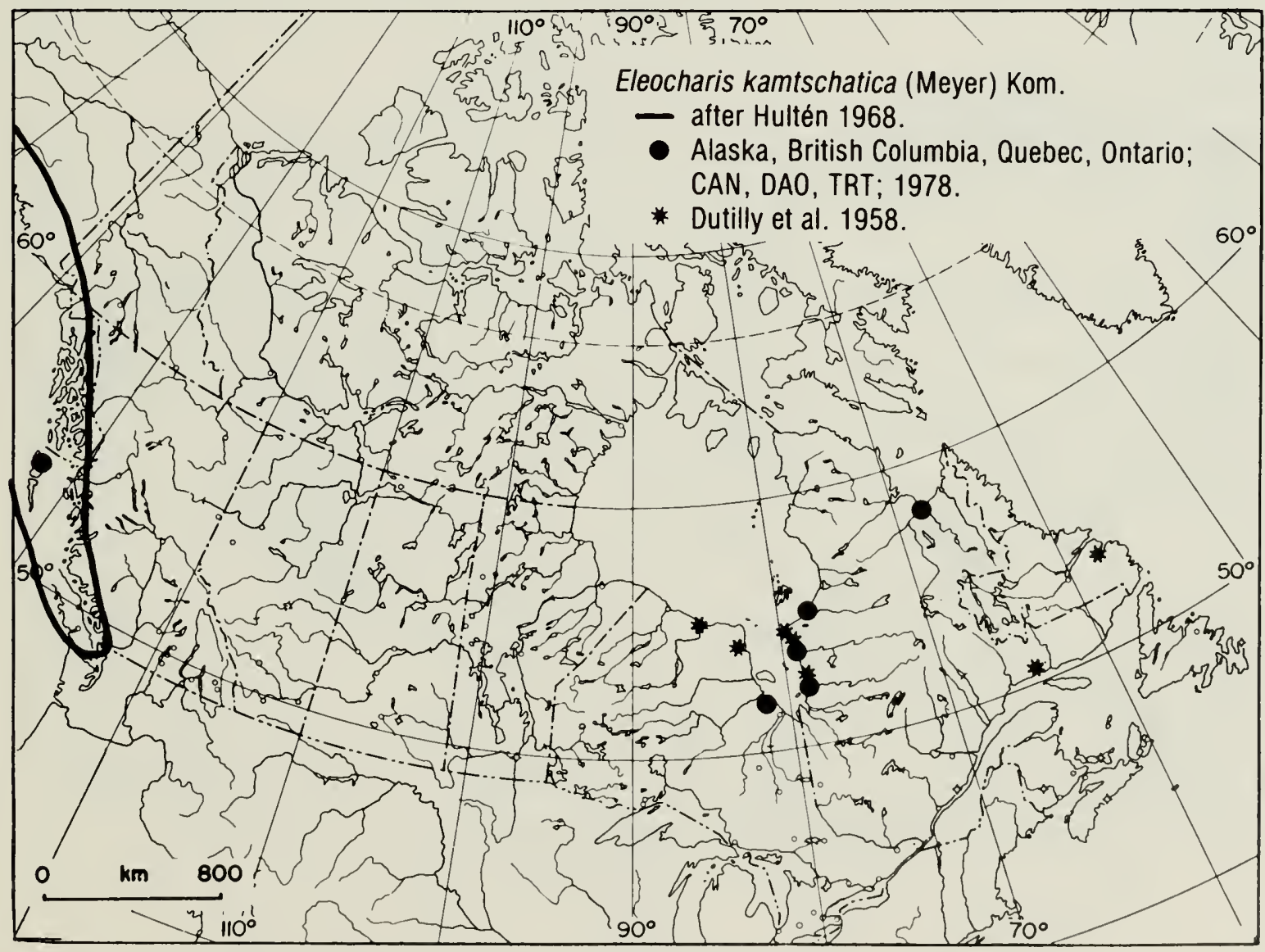

Fig. 28 Eleocharis kamtschatica. North American distribution. 


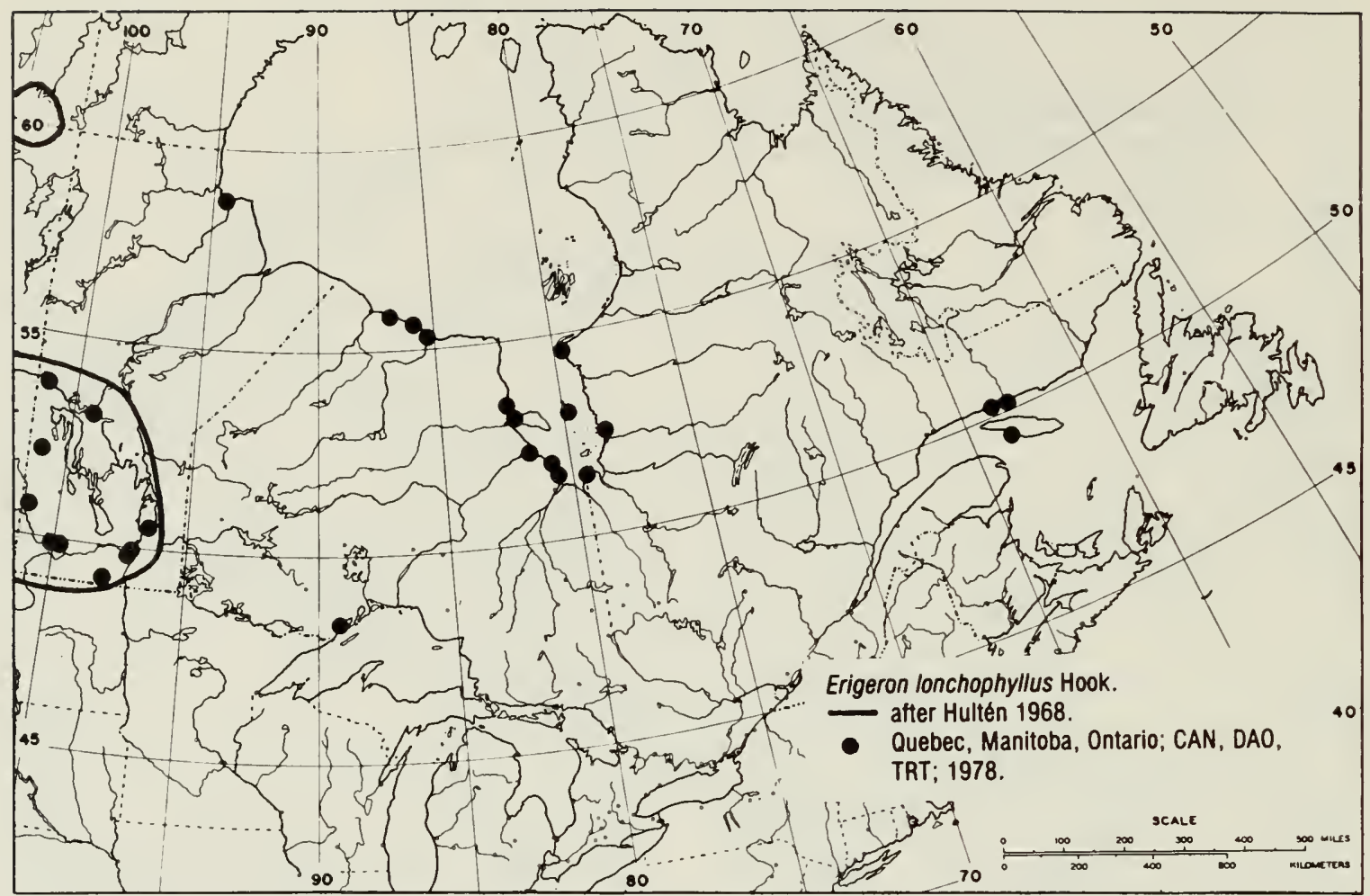

Fig. 29 Erigeron lonchophyllus. Northeastern North American distribution.

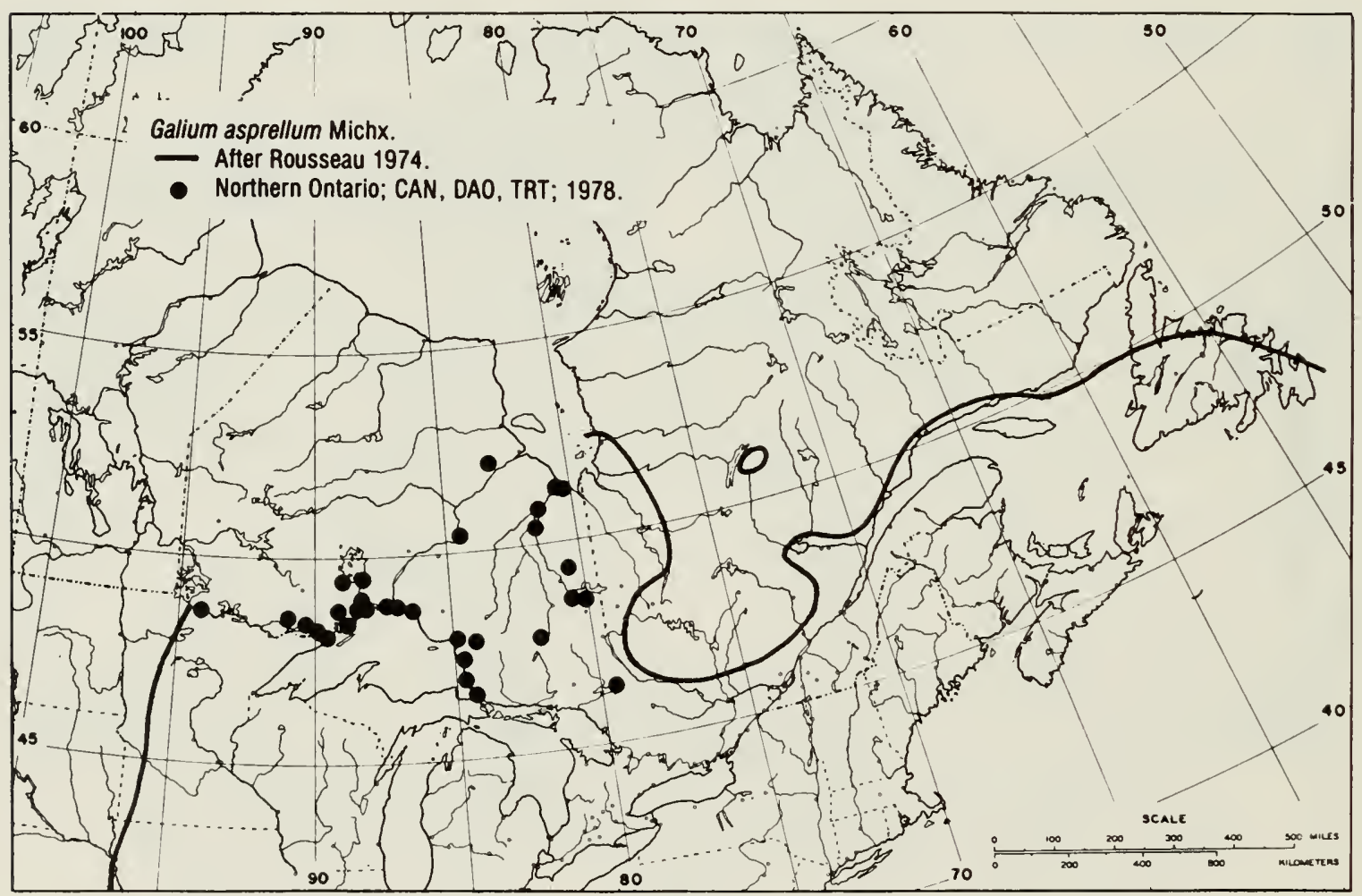

Fig. 30 Galium asprellum. Northeastern North American distribution. 


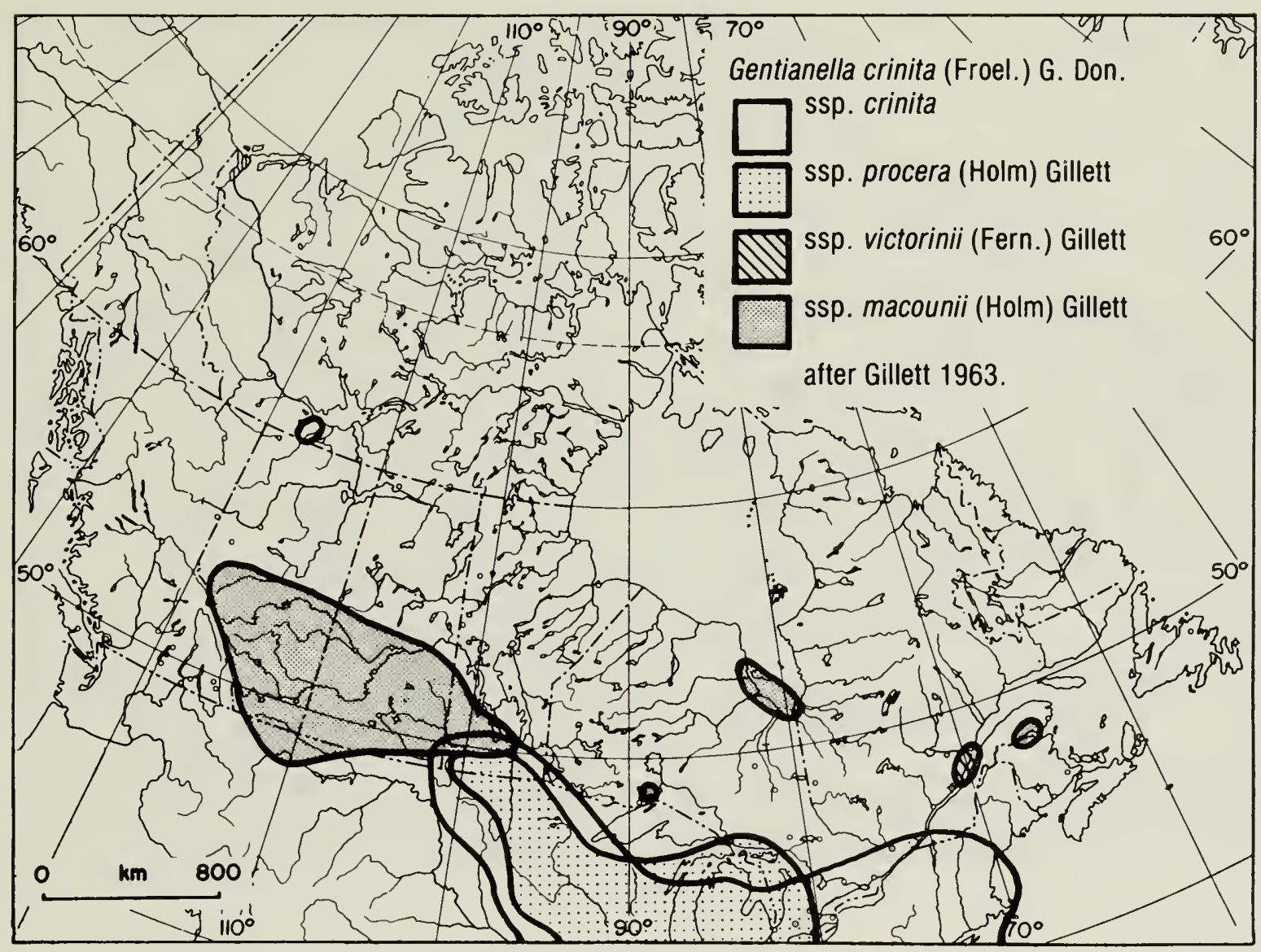

Fig. 31 Gentianella crinita. North American distribution.

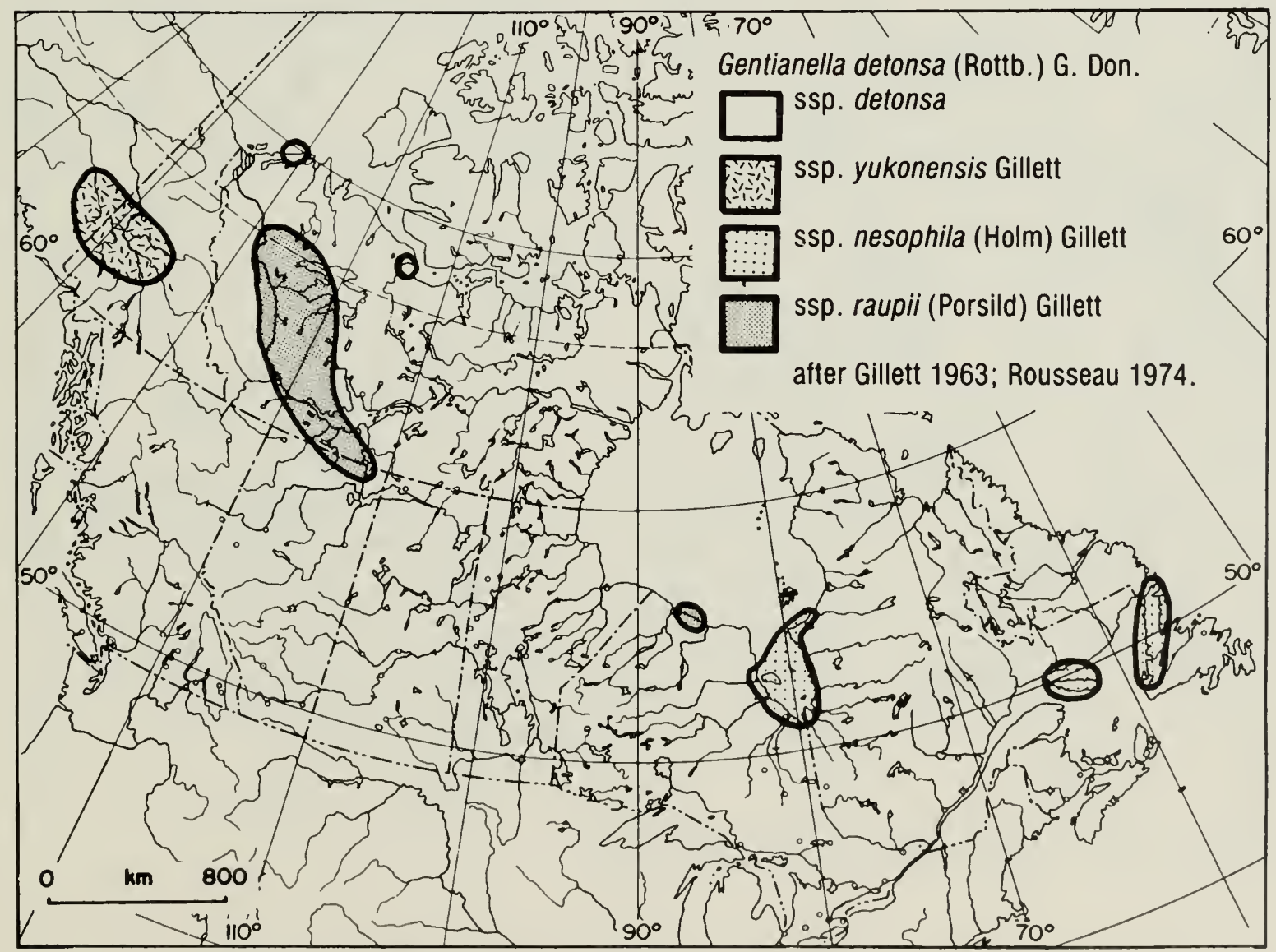

Fig. 32 Gentianella detonsa. North American distribution. 


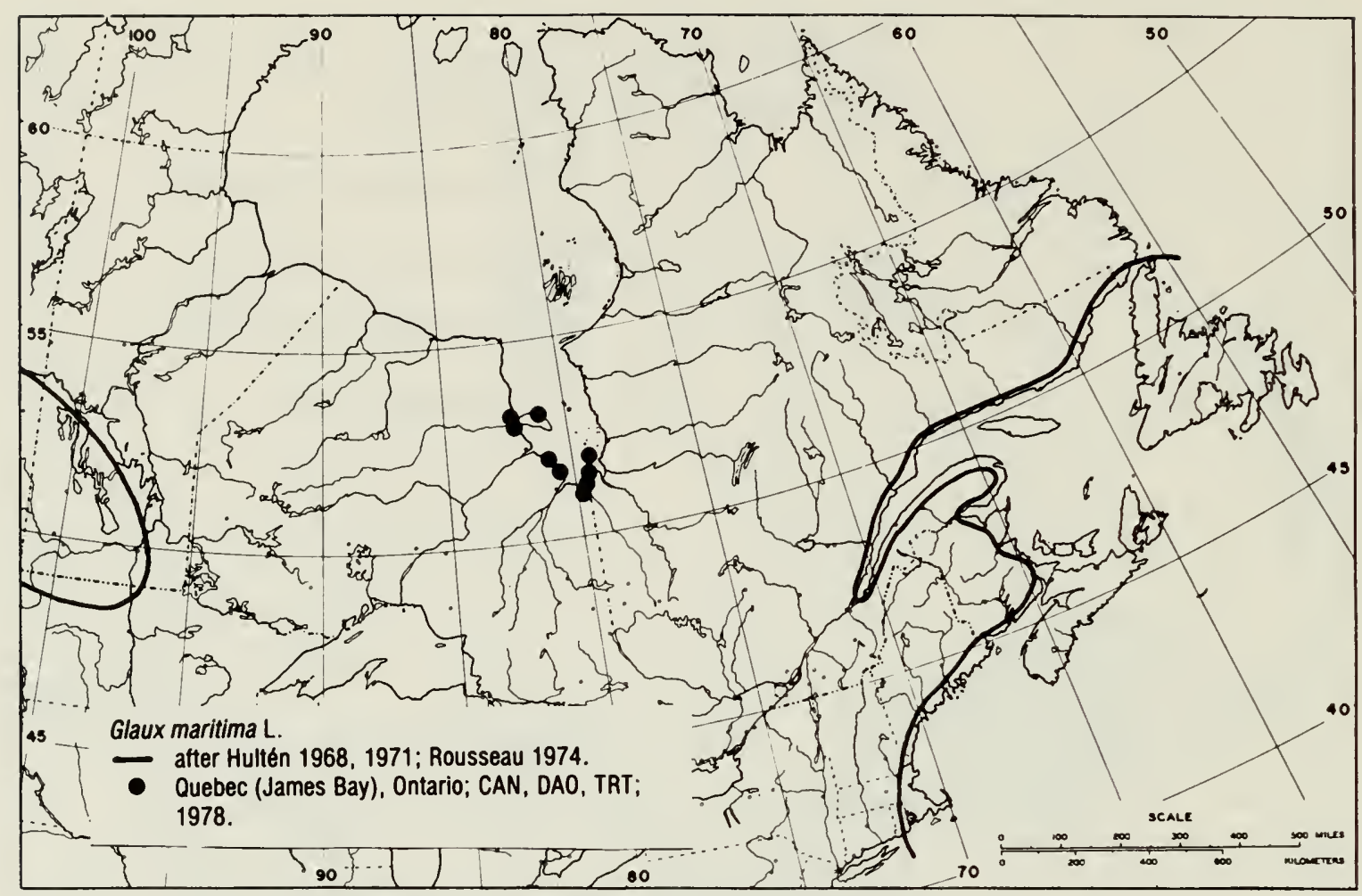

Fig. 33 Glaux maritima. Northeastern North American distribution.

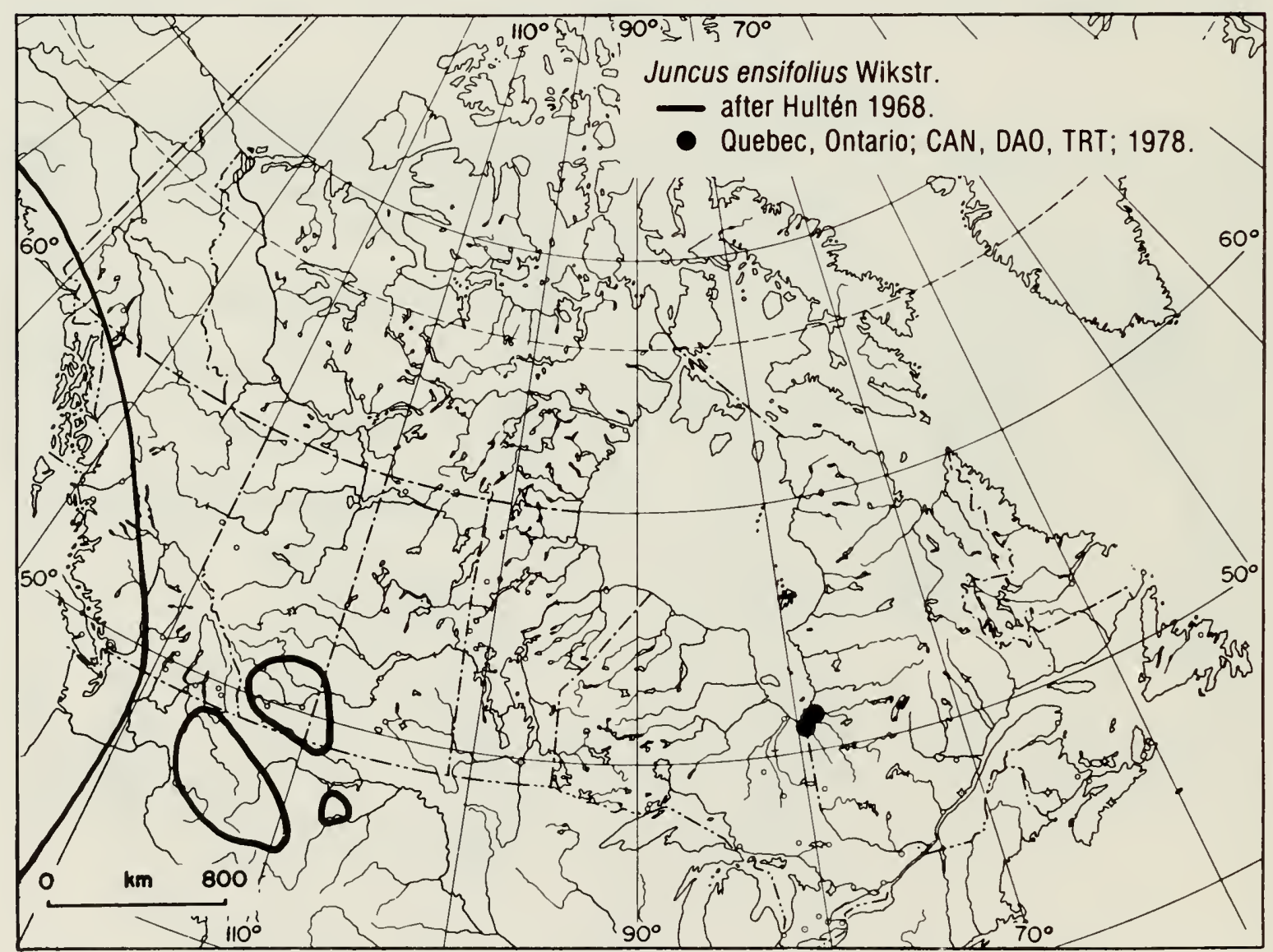

Fig. 34 Juncus ensifolius. North American distribution. 


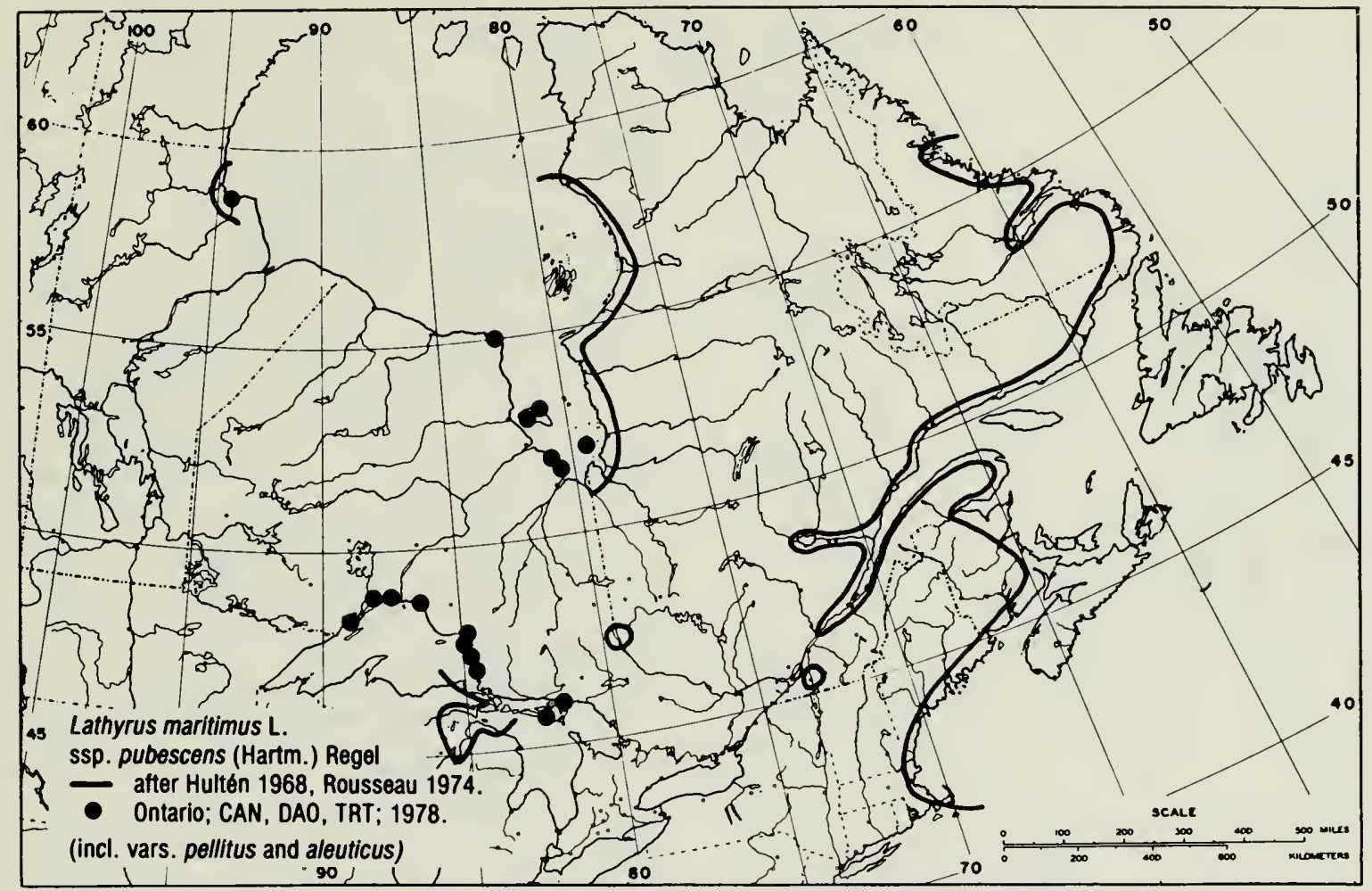

Fig. 35 Lathyrus maritimus ssp. pubescens. Northeastern North American distribution.

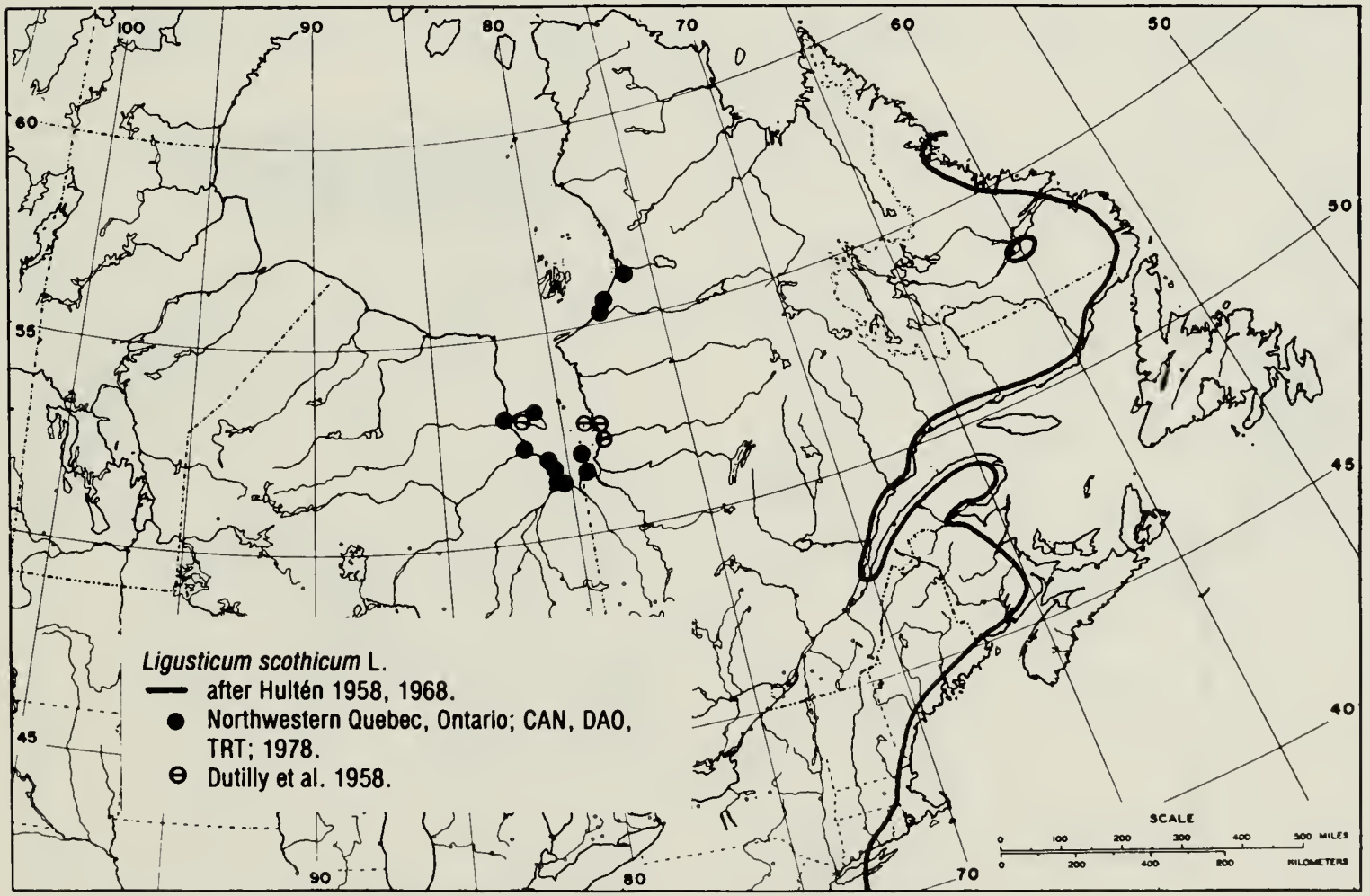

Fig. 36 Ligusticum scothicum. Northeastern North American distribution. 


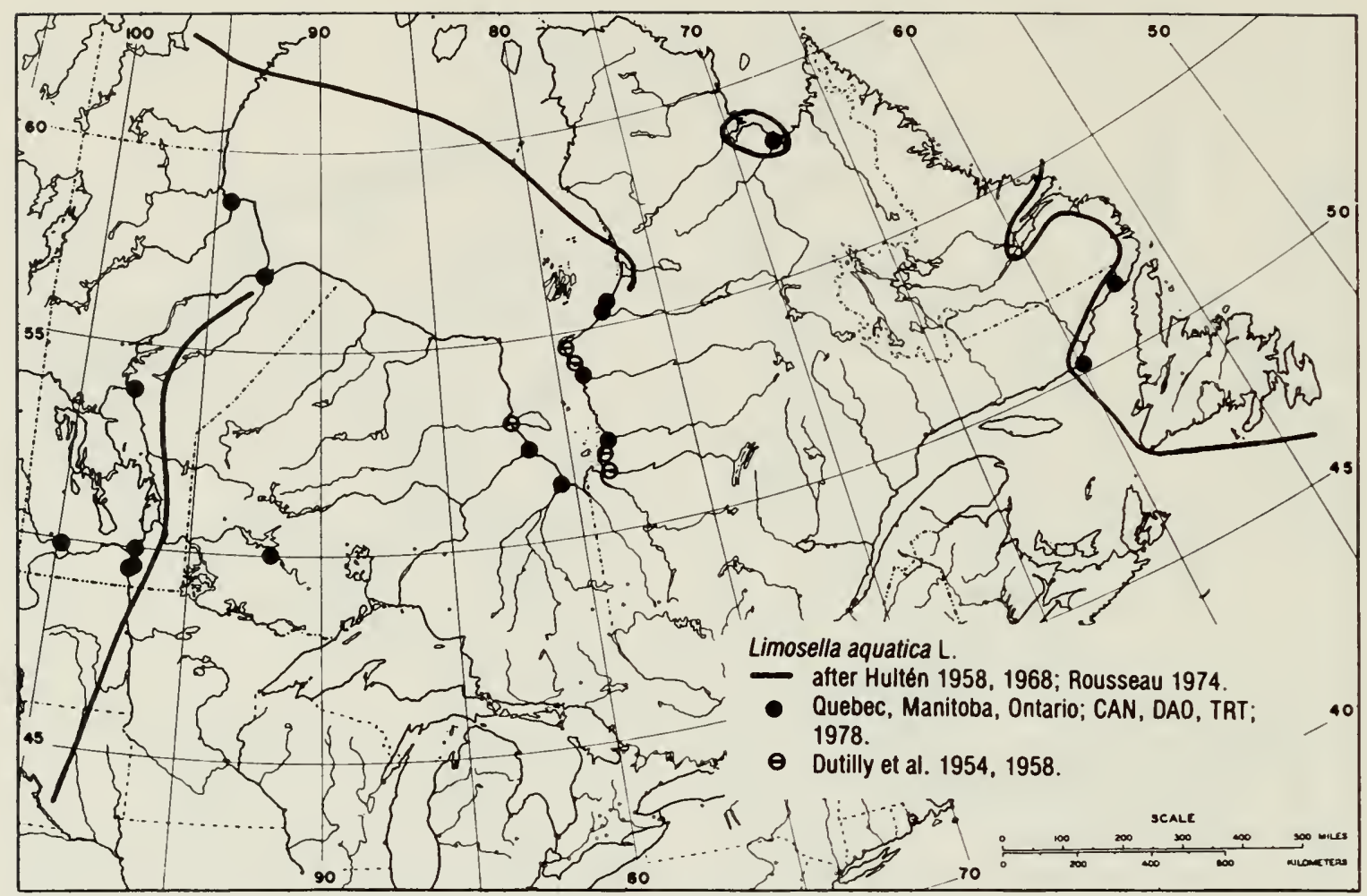

Fig. 37 Limosella aquatica. Northeastern North American distribution.

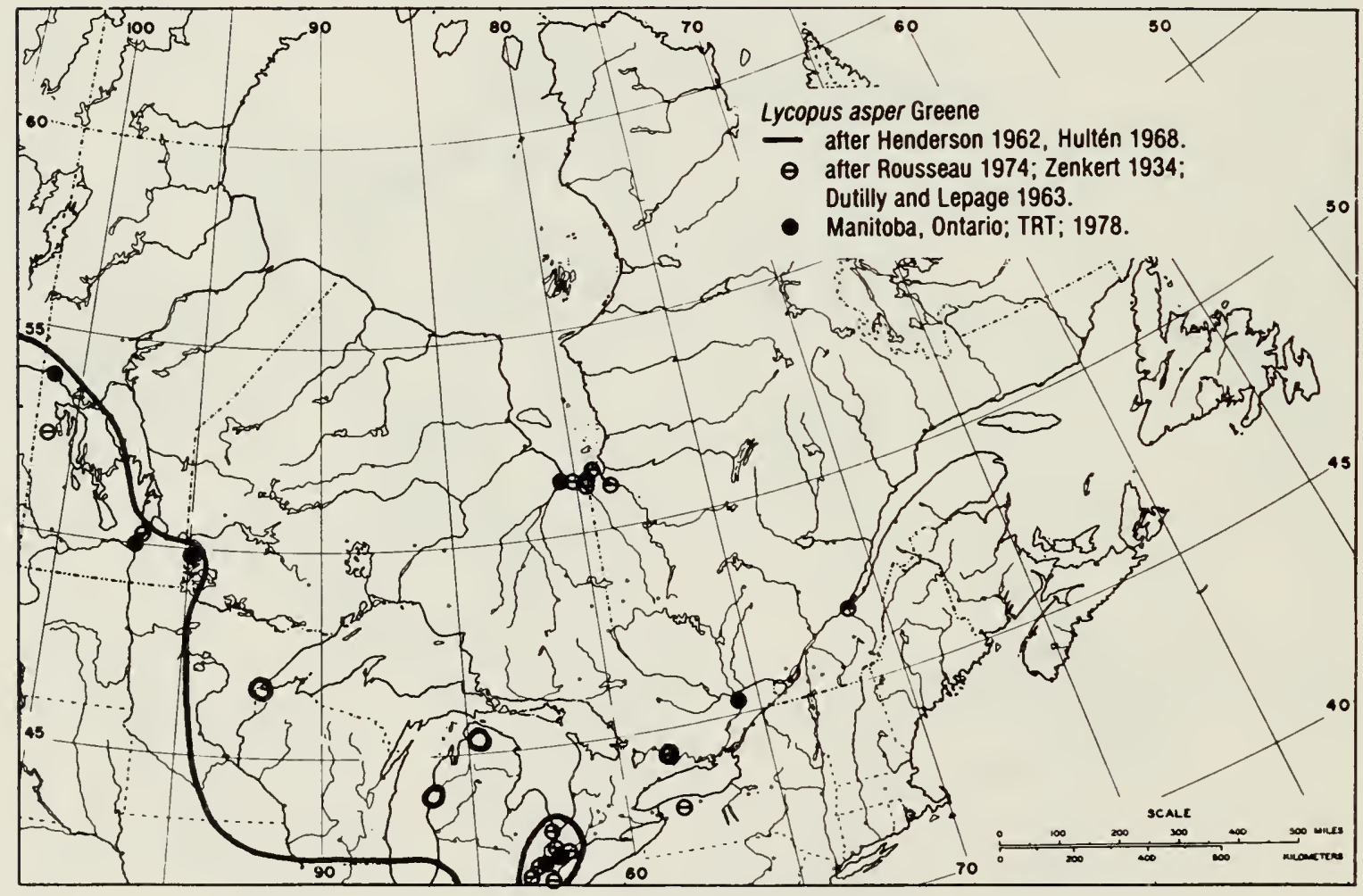

Fig. 38 Lycopus asper. Northeastern North American distribution. 


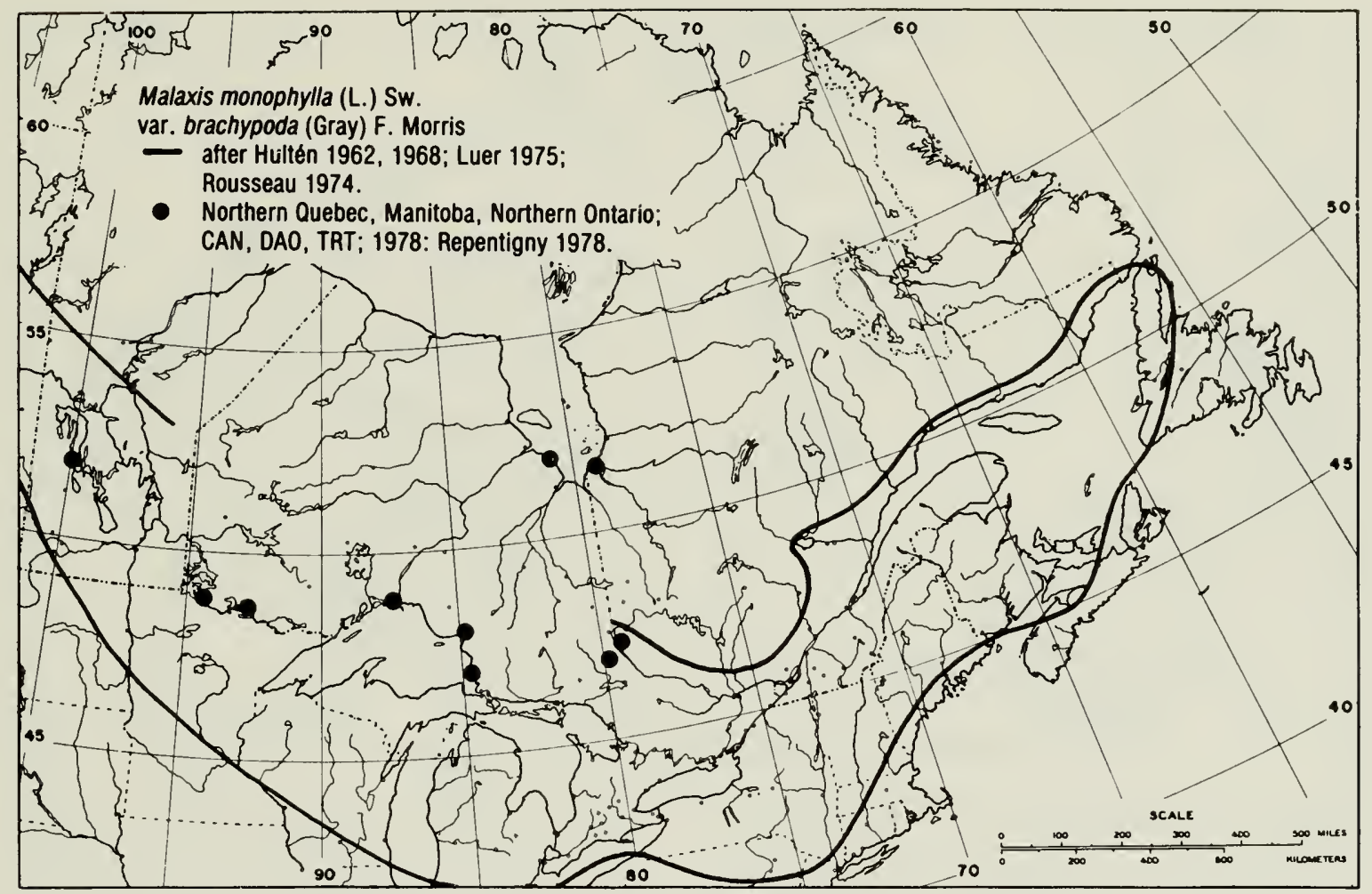

Fig. 39 Malaxis monophylla var. brachypoda. Northeastern North American distribution.

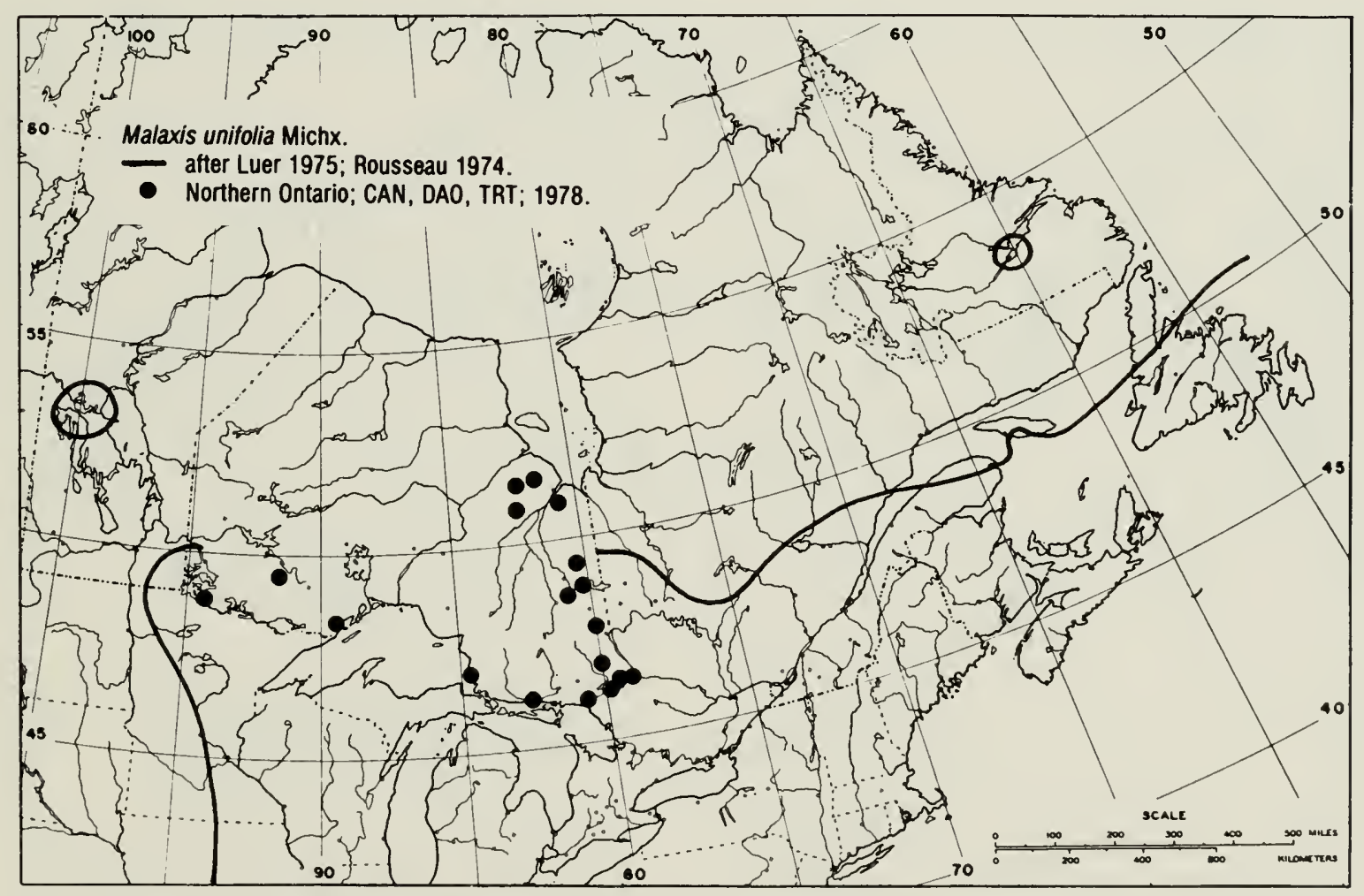

Fig. 40 Malaxis unifolia. Northeastern North American distribution. 


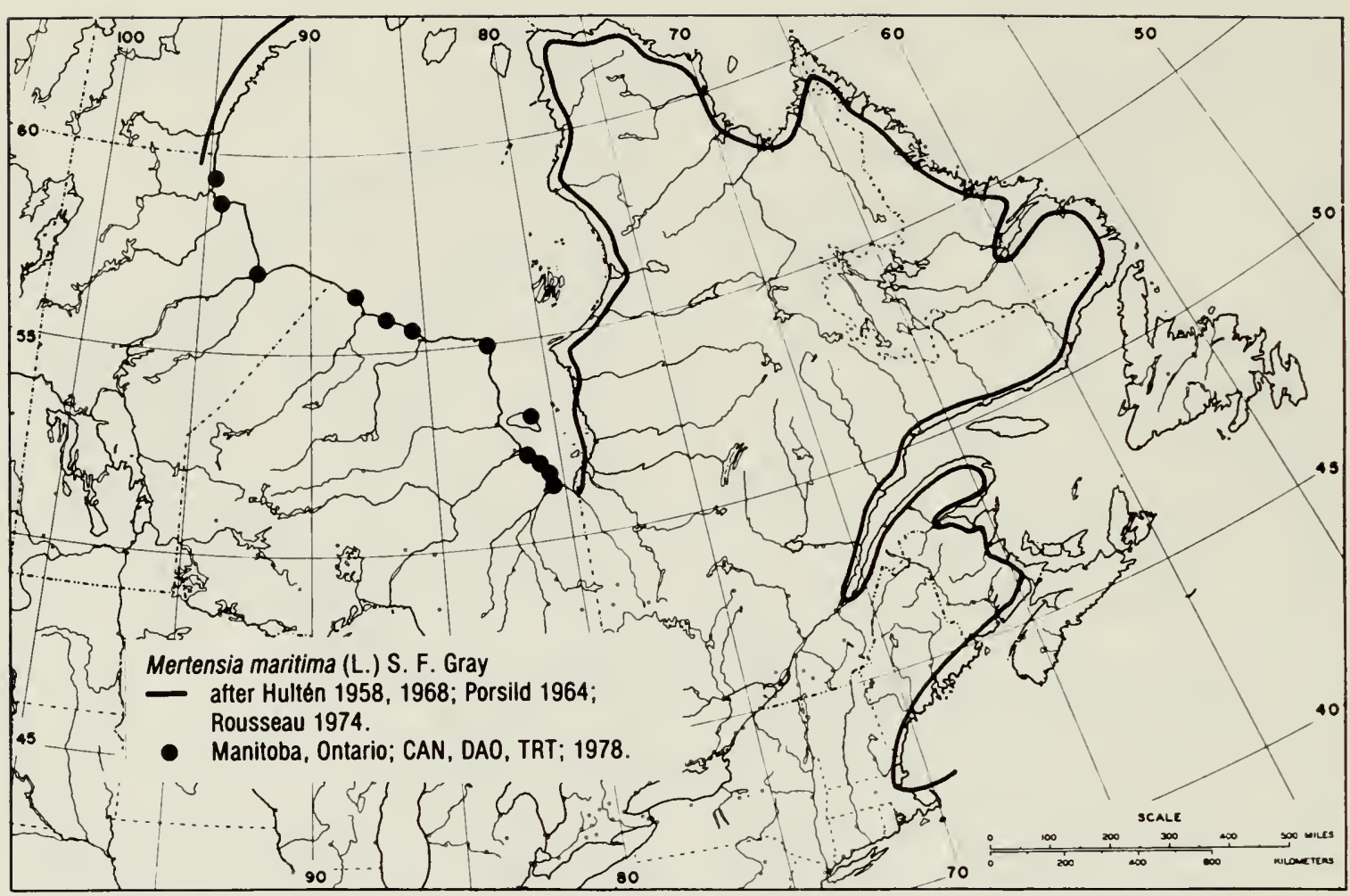

Fig. 41 Mertensia maritima. Northeastern North American distribution.

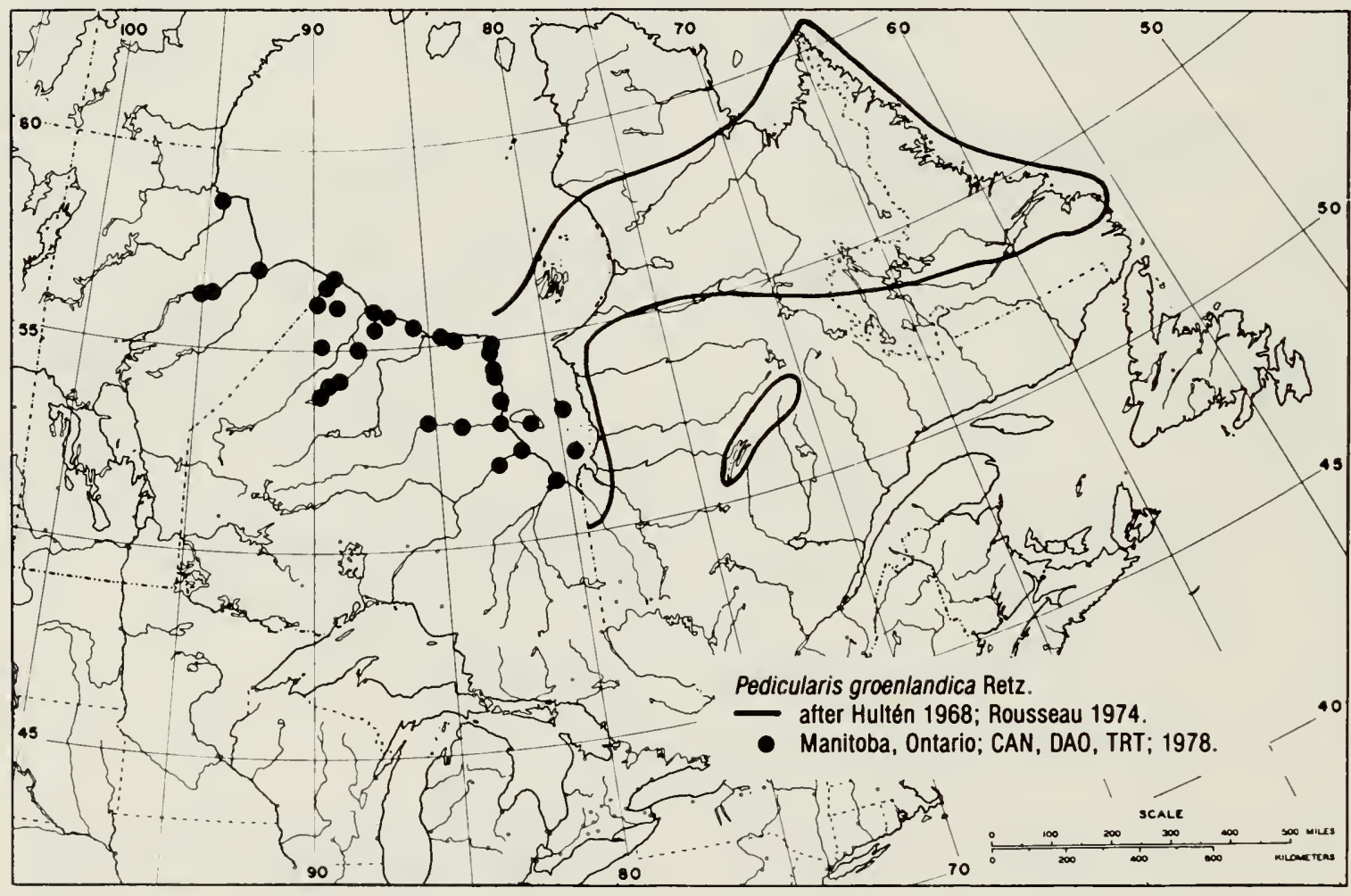

Fig. 42 Pedicularis groenlandica. Northeastern North American distribution. 


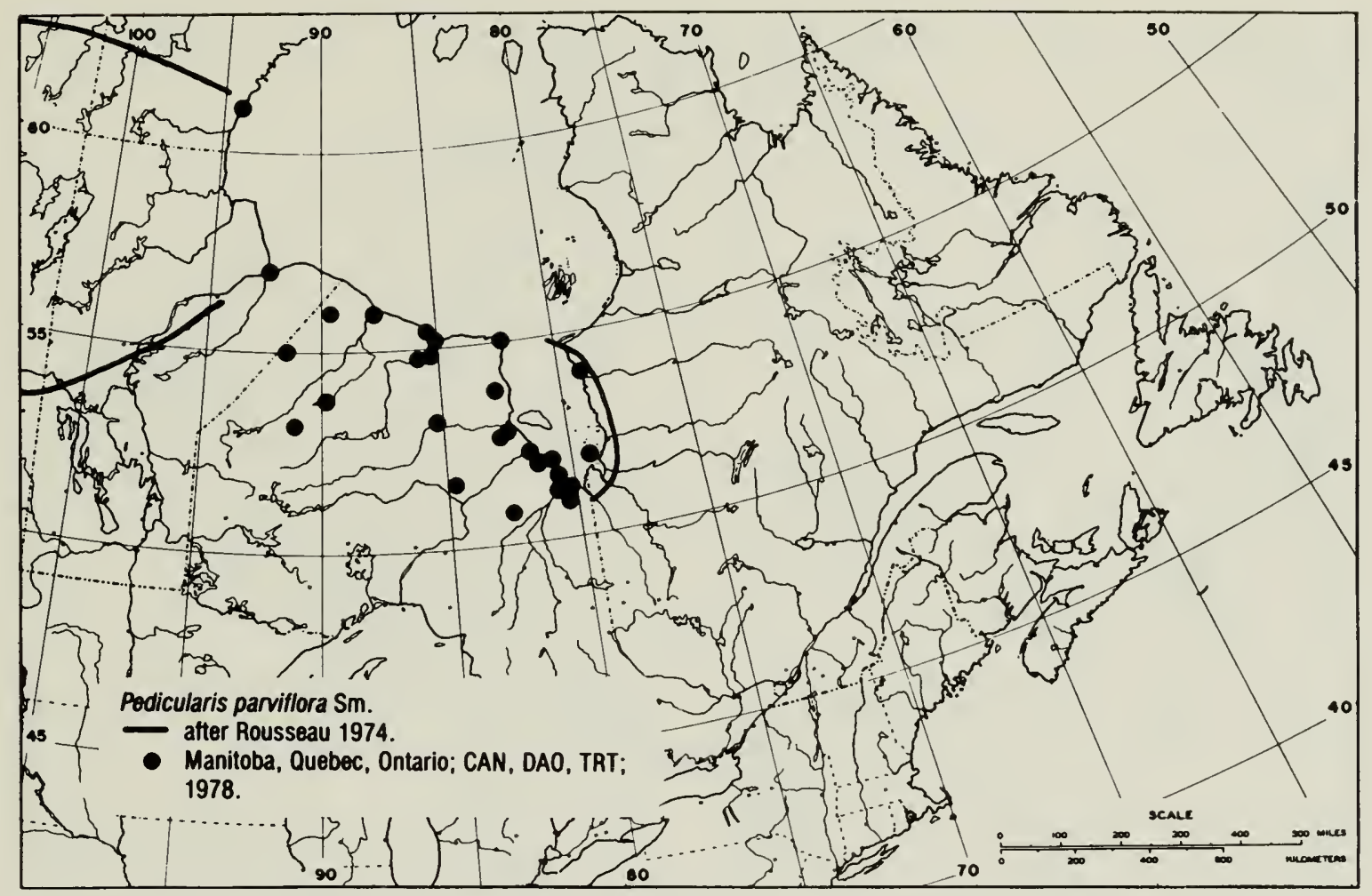

Fig. 43 Pedicularis parviflora. Northeastern North American distribution.

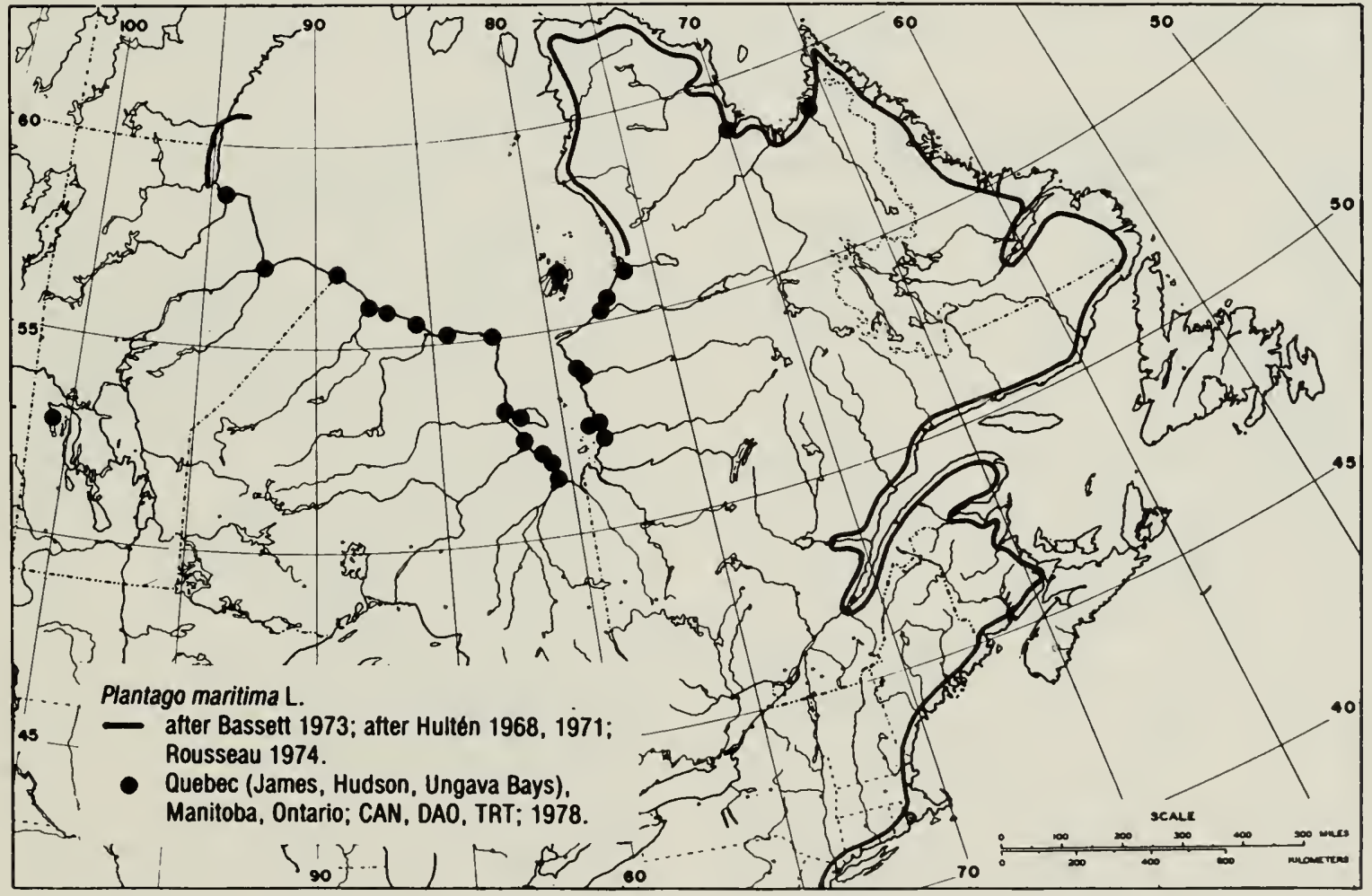

Fig. 44 Plantago maritima. Northeastern North American distribution. 


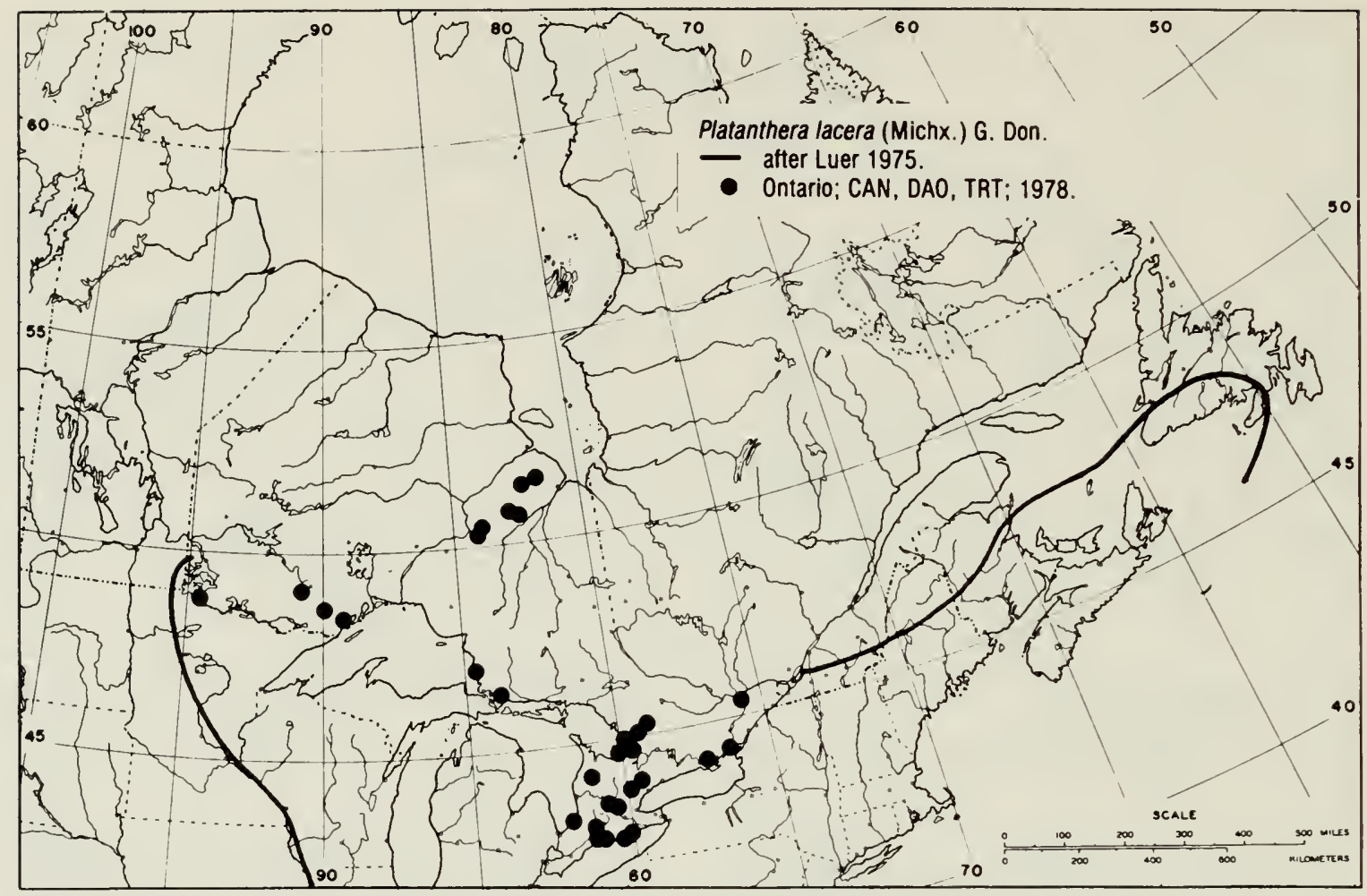

Fig. 45 Platanthera lacera. Northeastern North American distribution.

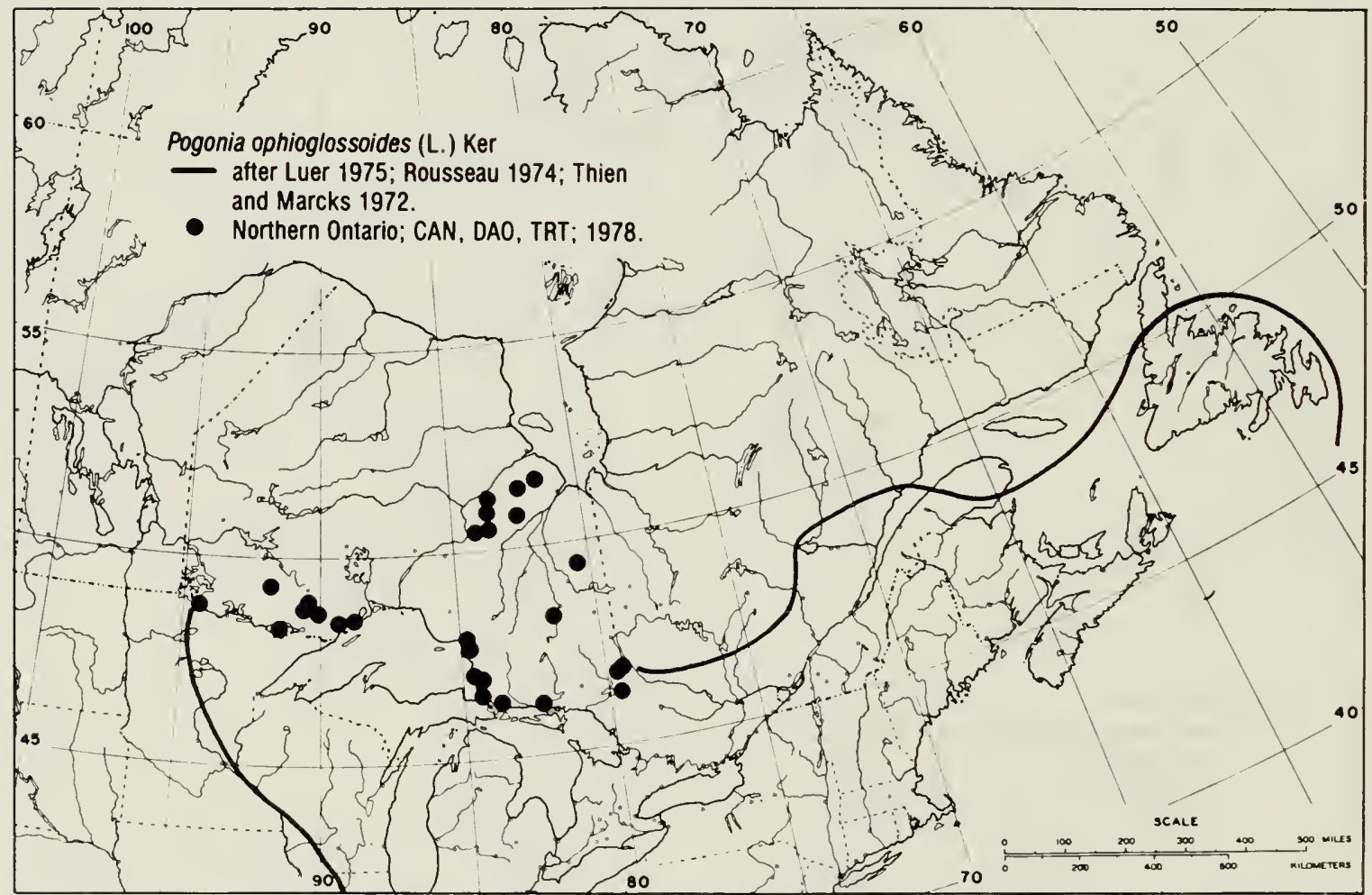

Fig. 46 Pogonia ophioglossoides. Northeastern North American distribution. 


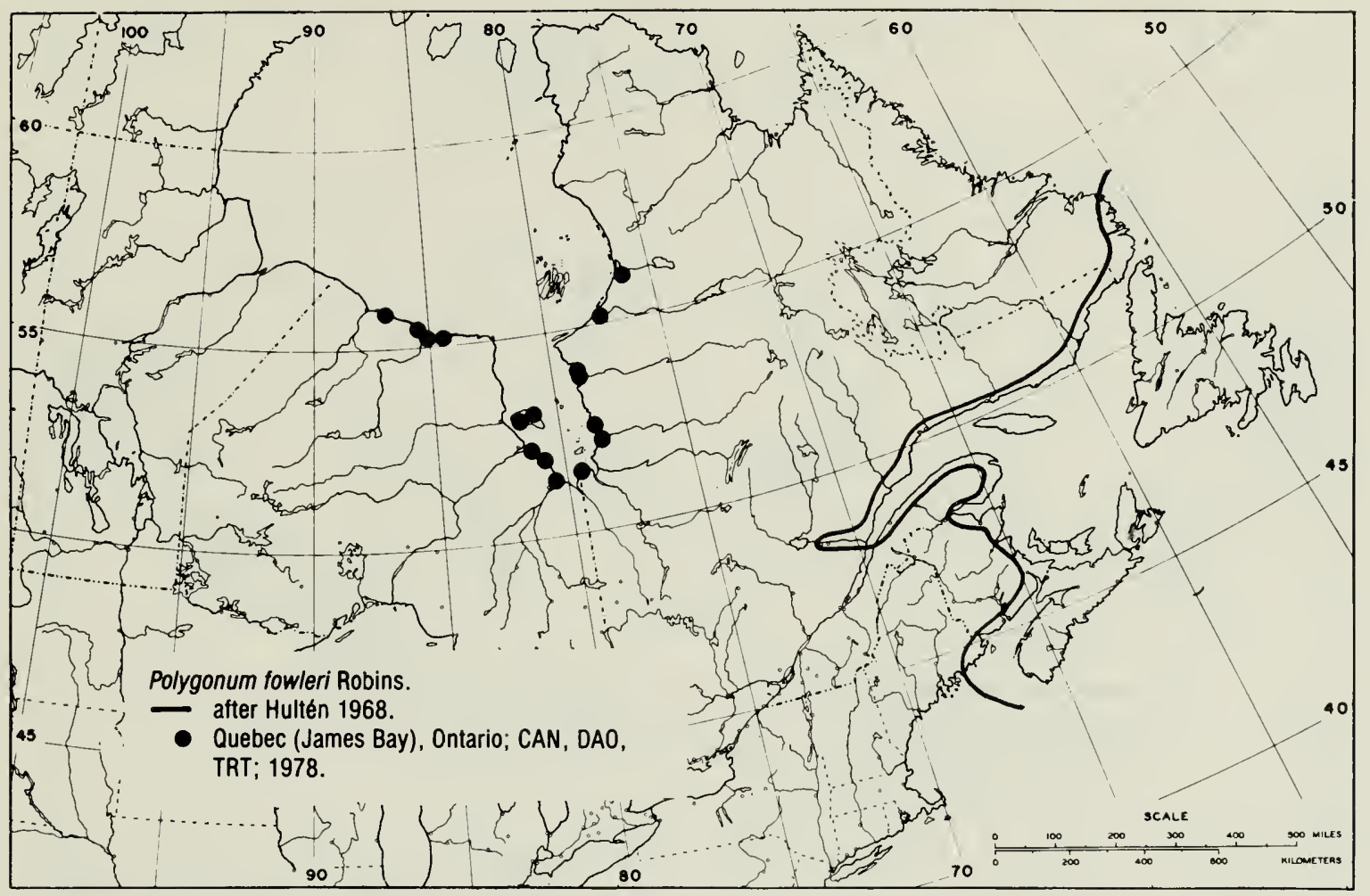

Fig. 47 Polygonum fowleri. Northeastern North American distribution.

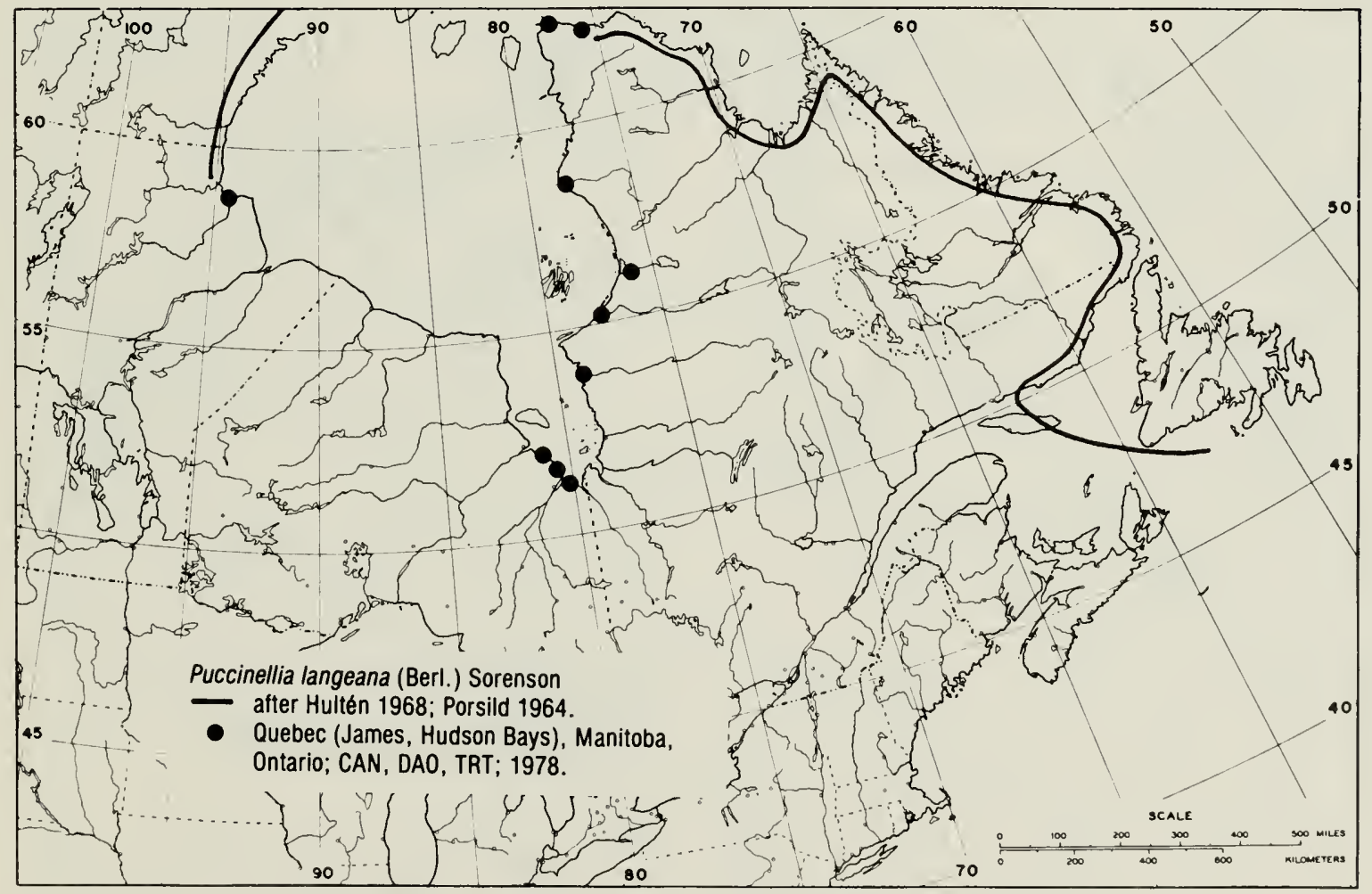

Fig. 48 Puccinellia langeana. Northeastern North American distribution. 


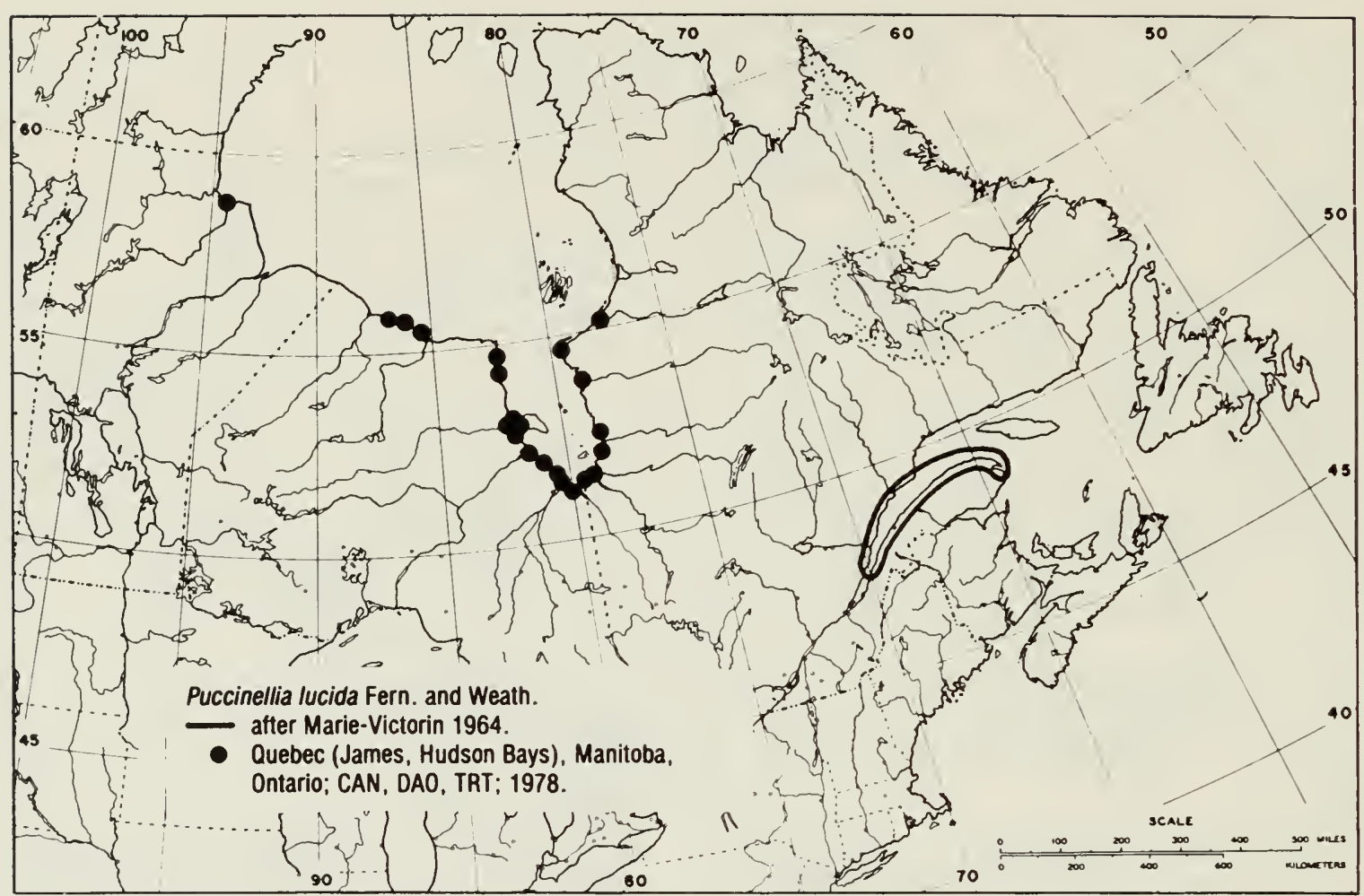

Fig. 49 Puccinellia lucida. Northeastern North American distribution.

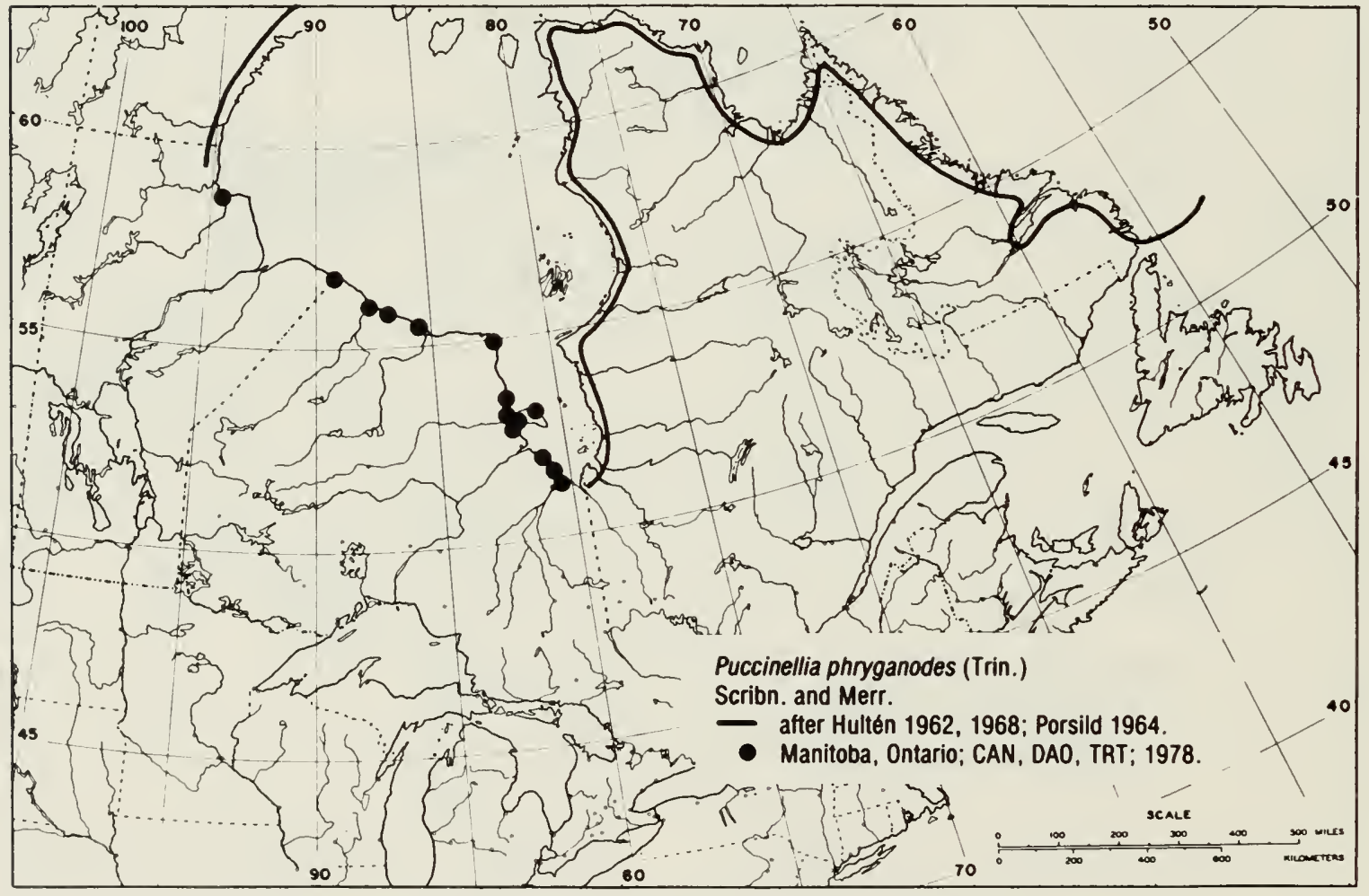

Fig. 50 Puccinellia phryganodes. Northeastern North American distribution. 


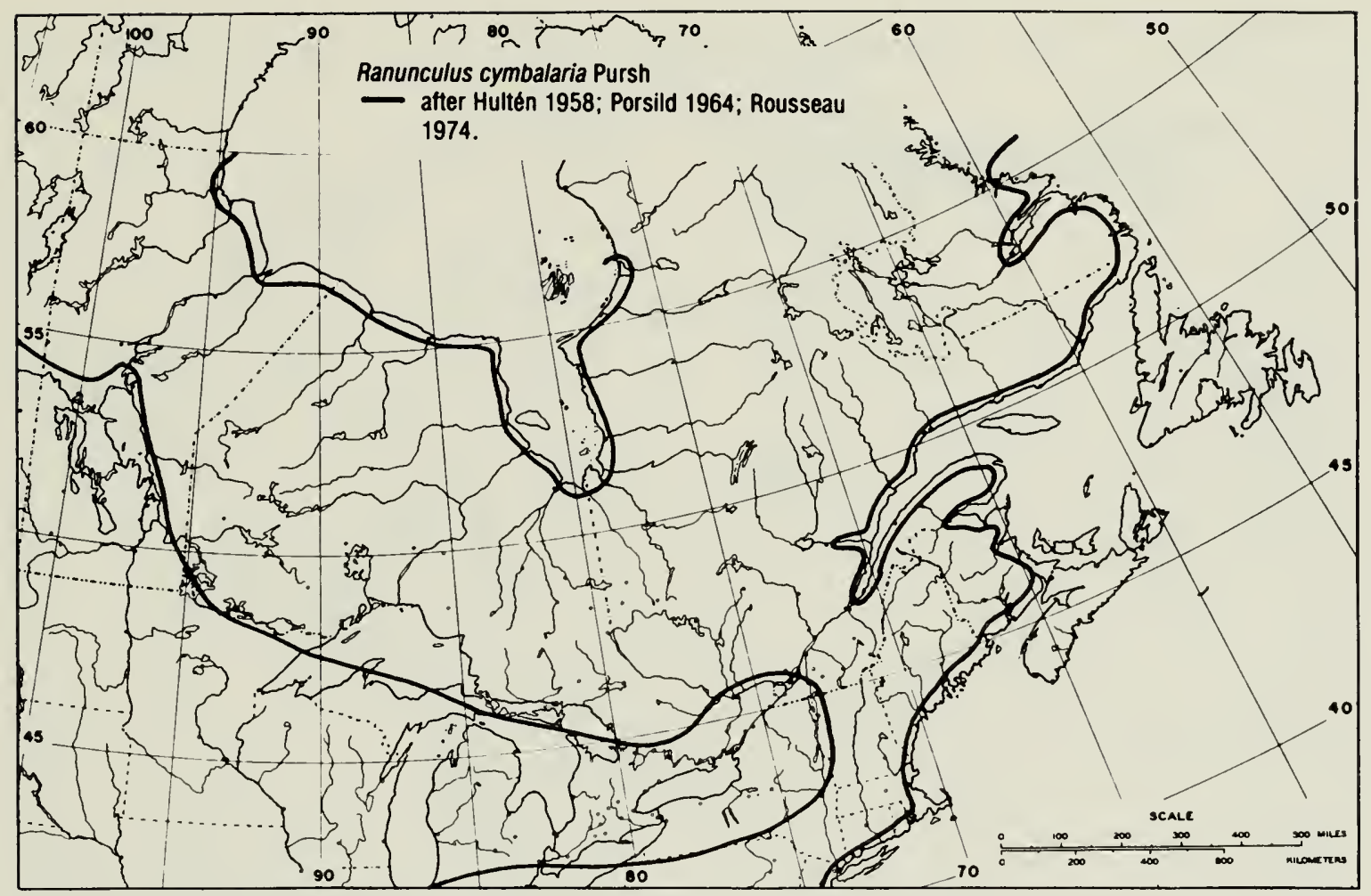

Fig. 51 Ranunculus cymbalaria. Northeastern North American distribution.

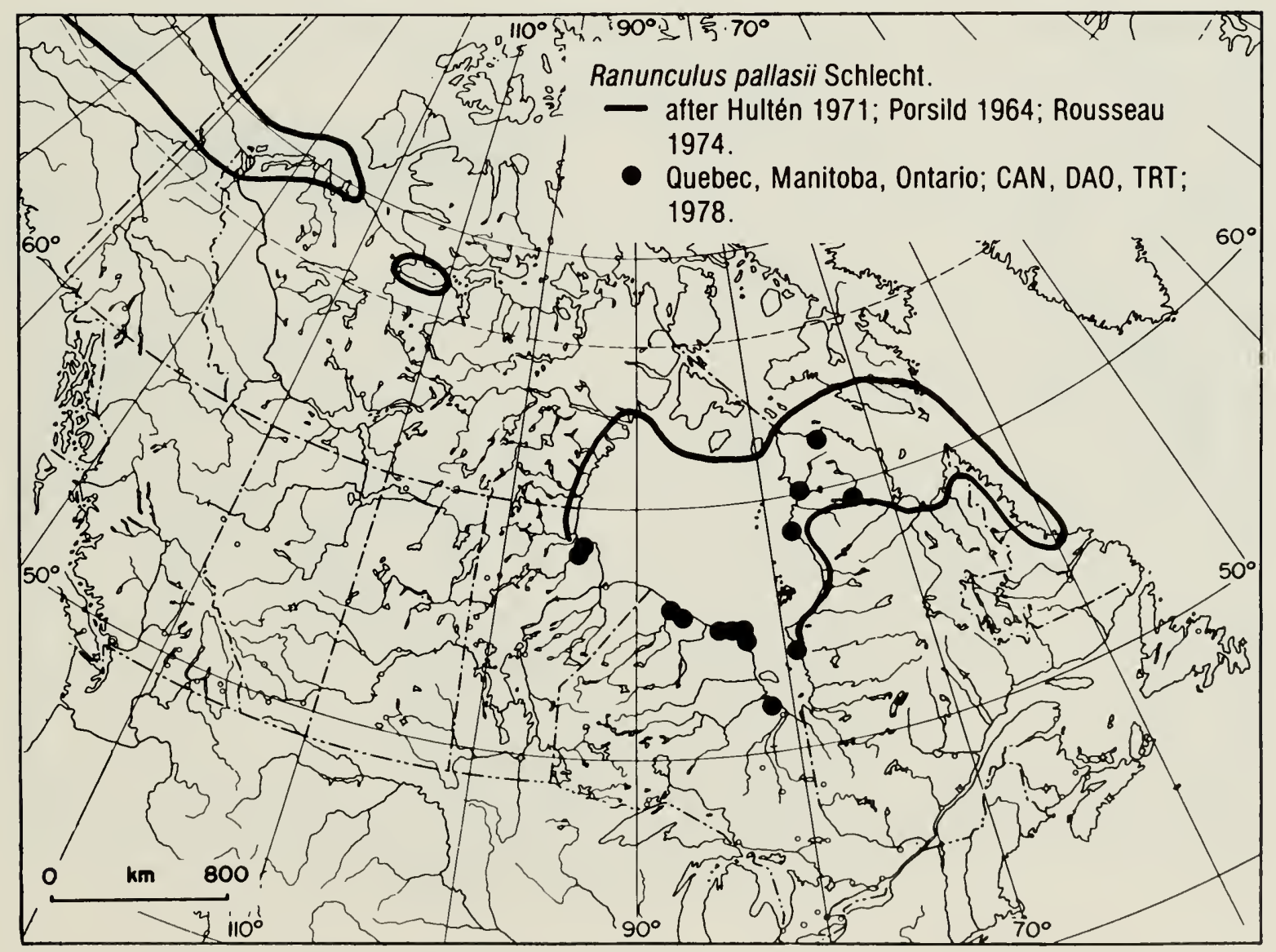

Fig. 52 Ranunculus pallasii. North American distribution. 


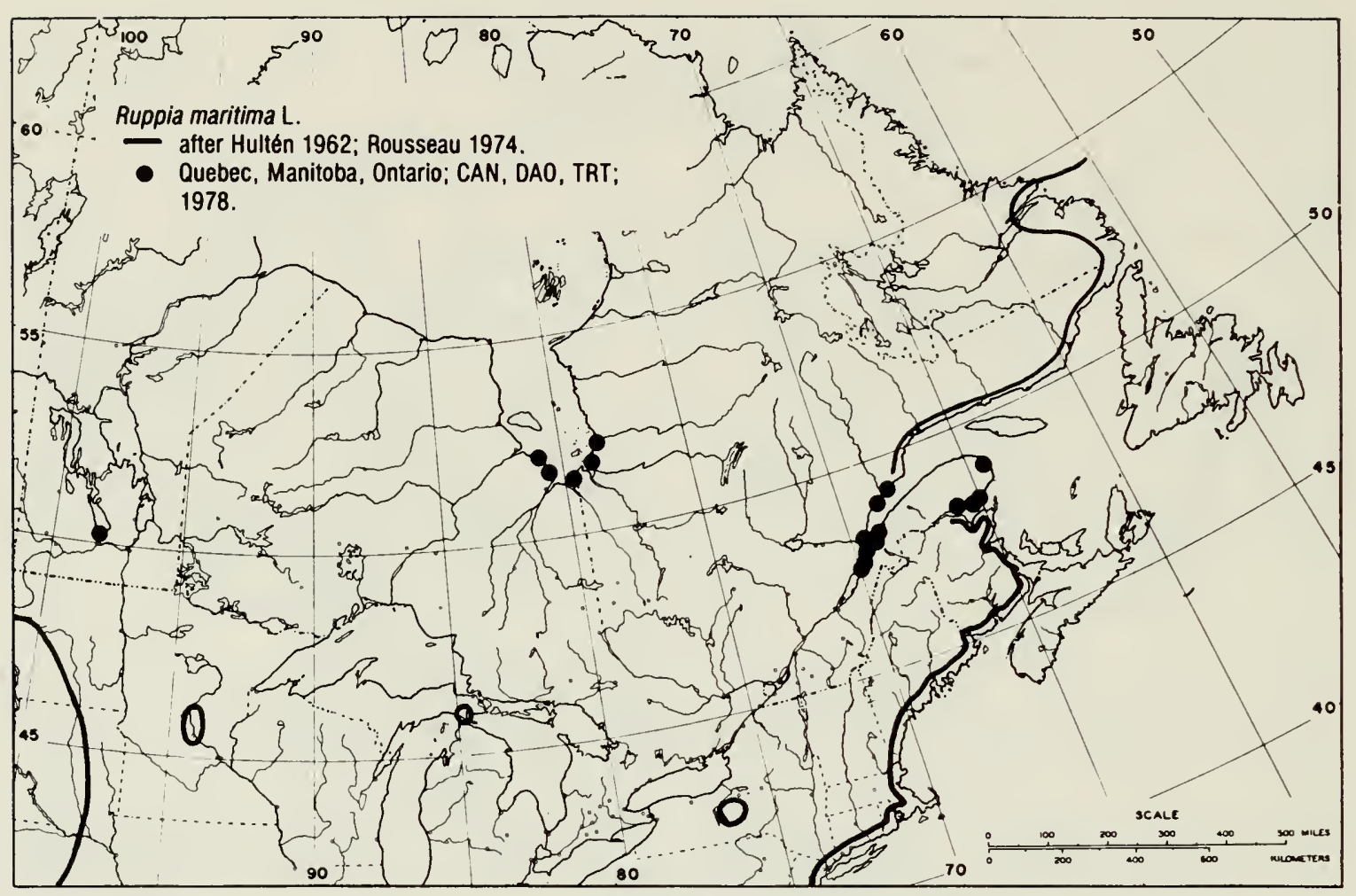

Fig. 53 Ruppia maritima. Northeastern North American distribution.

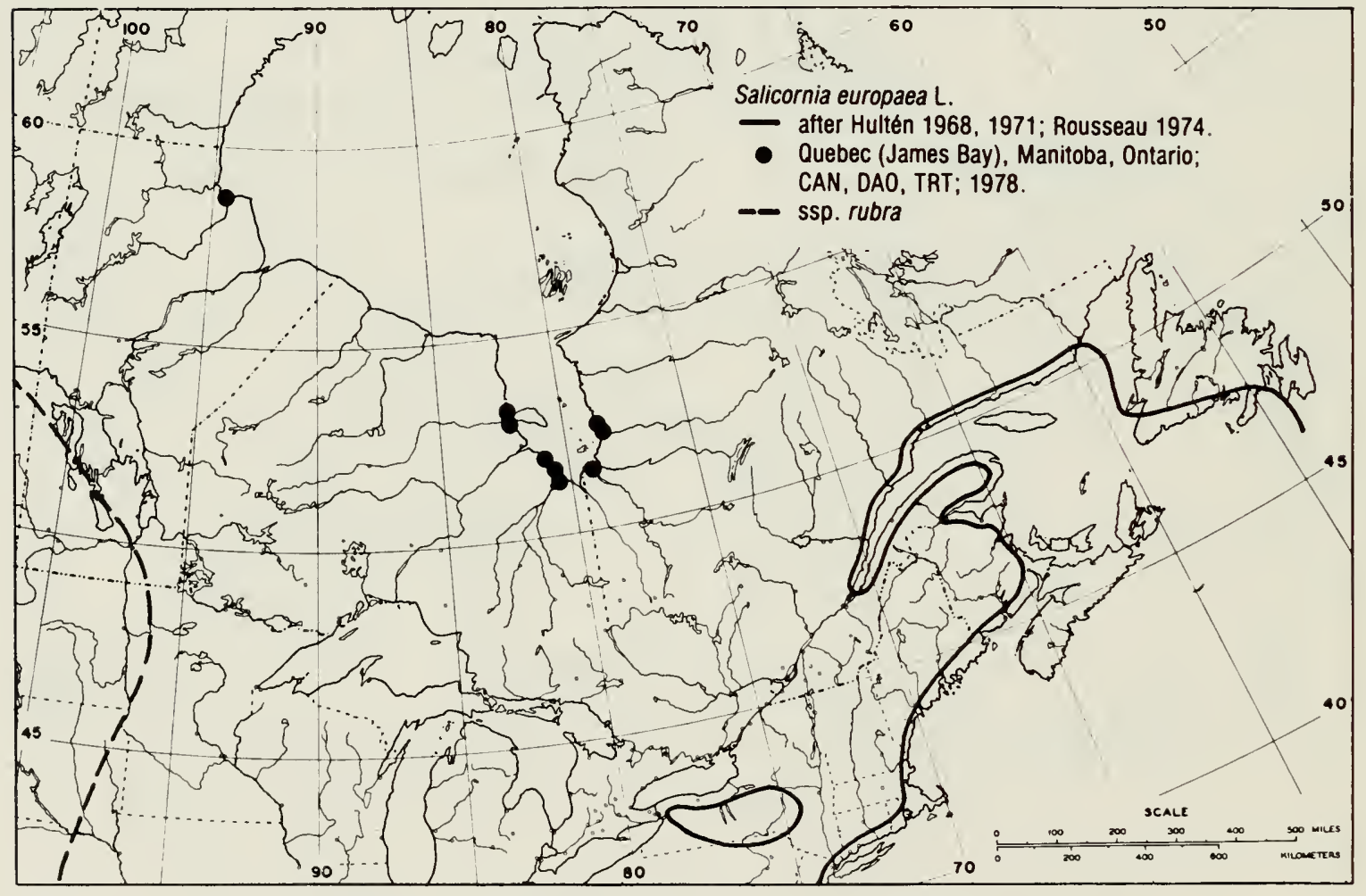

Fig. 54 Salicornia europaea. Northeastern North American distribution. 


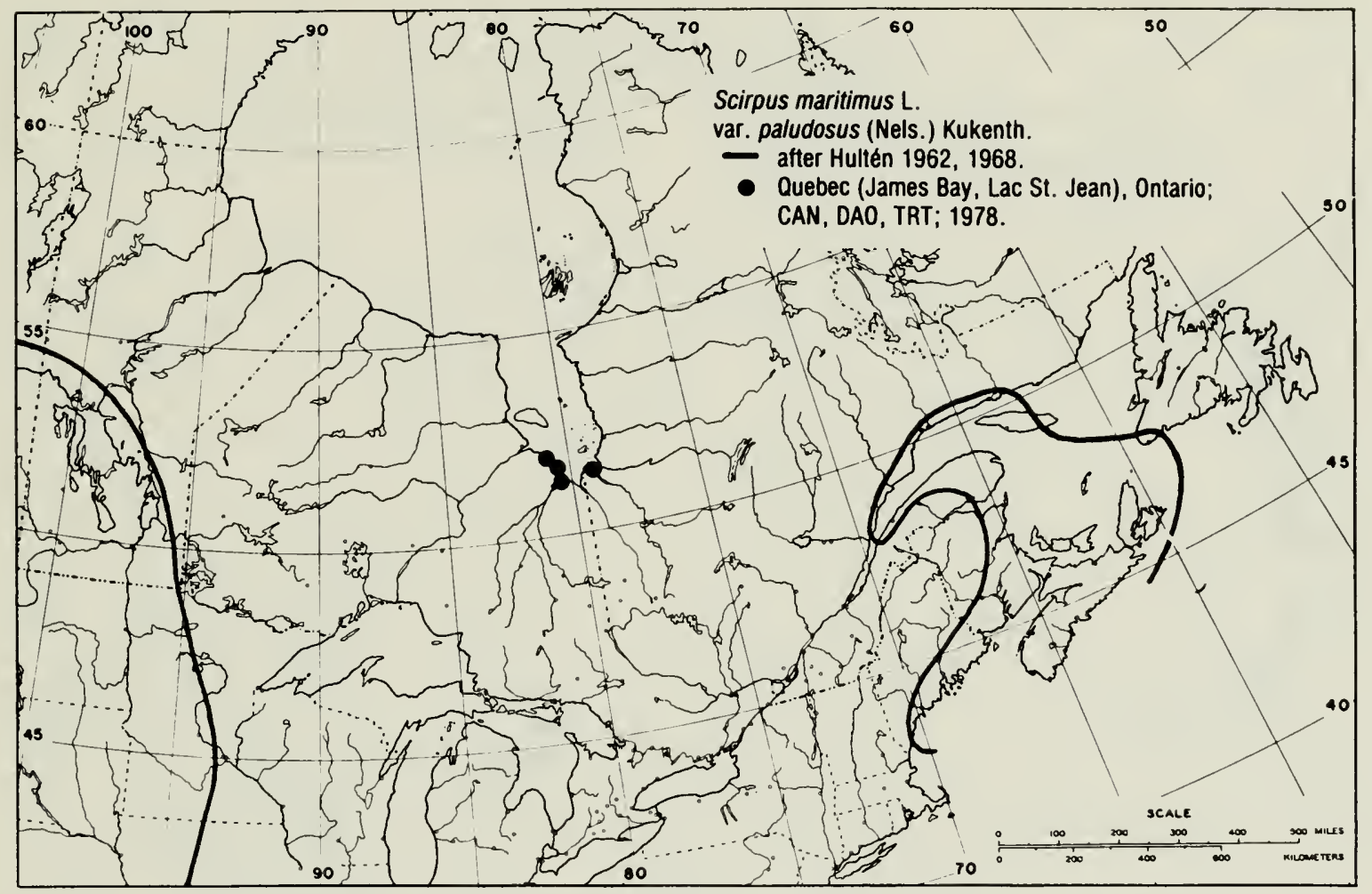

Fig. 55 Scirpus maritimus var. paludosus. Northeastern North American distribution.

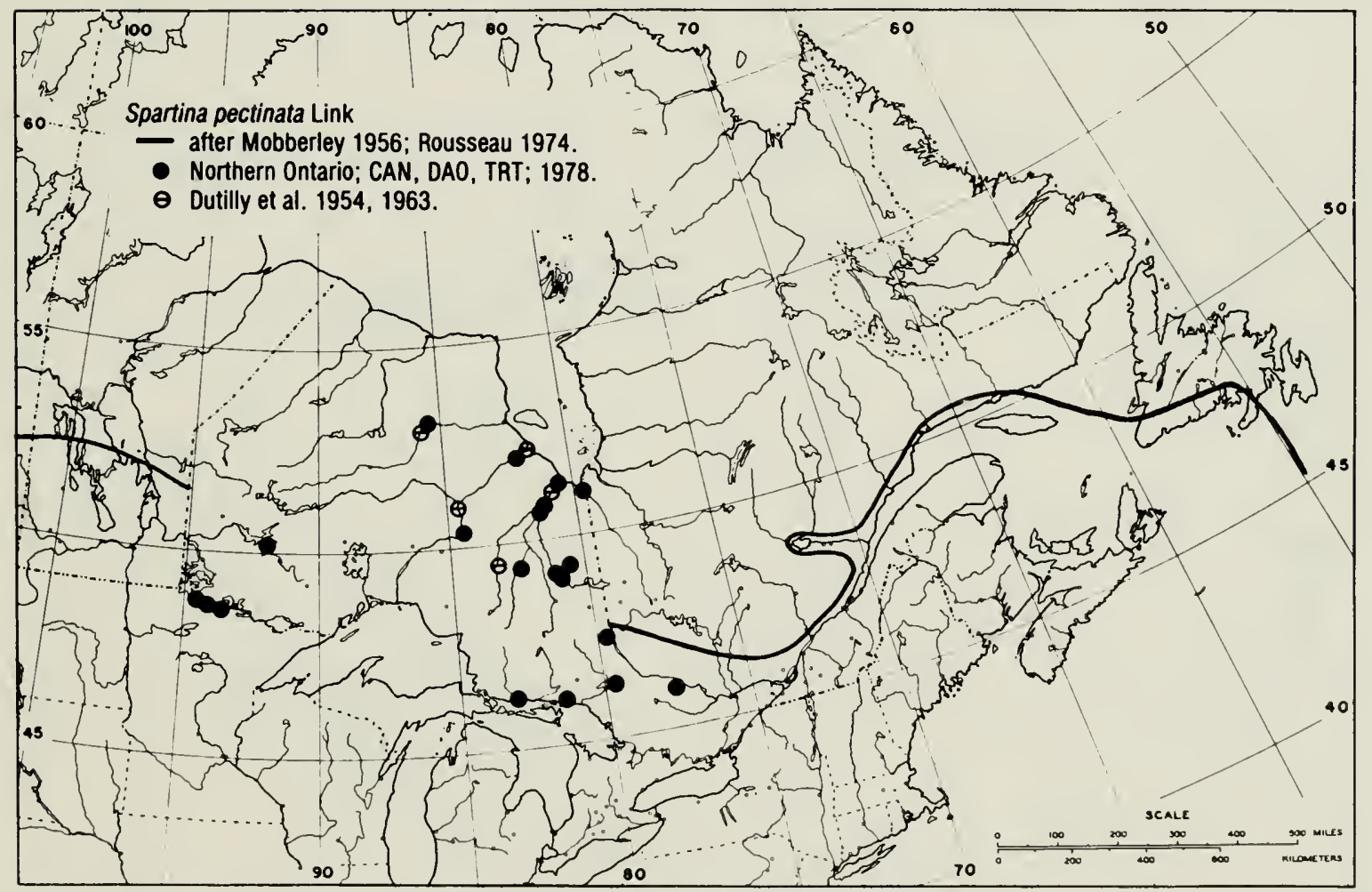

Fig. 56 Spartina pectinata. Northeastern North American distribution. 


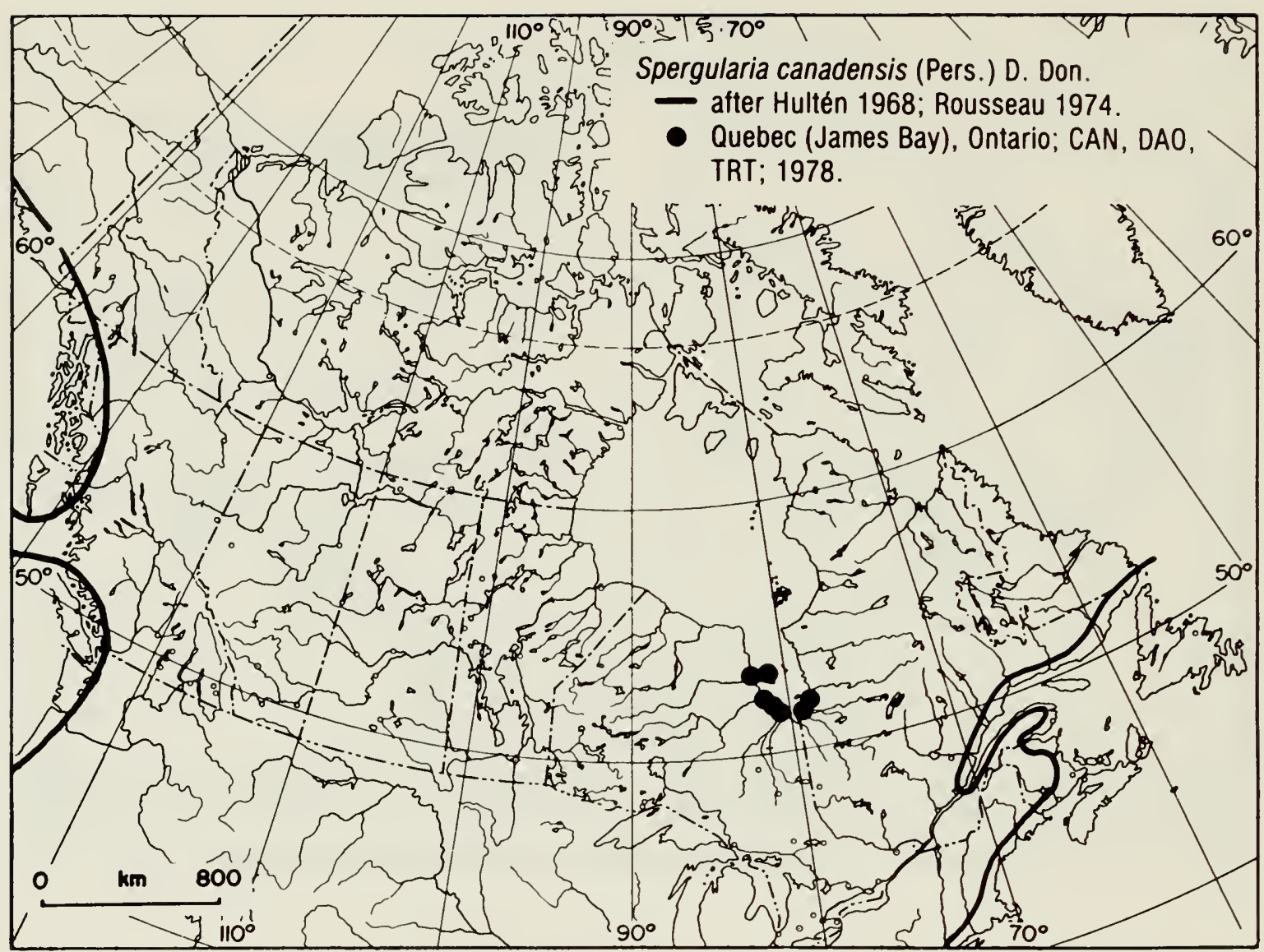

Fig. 57 Spergularia canadensis. North American distribution.

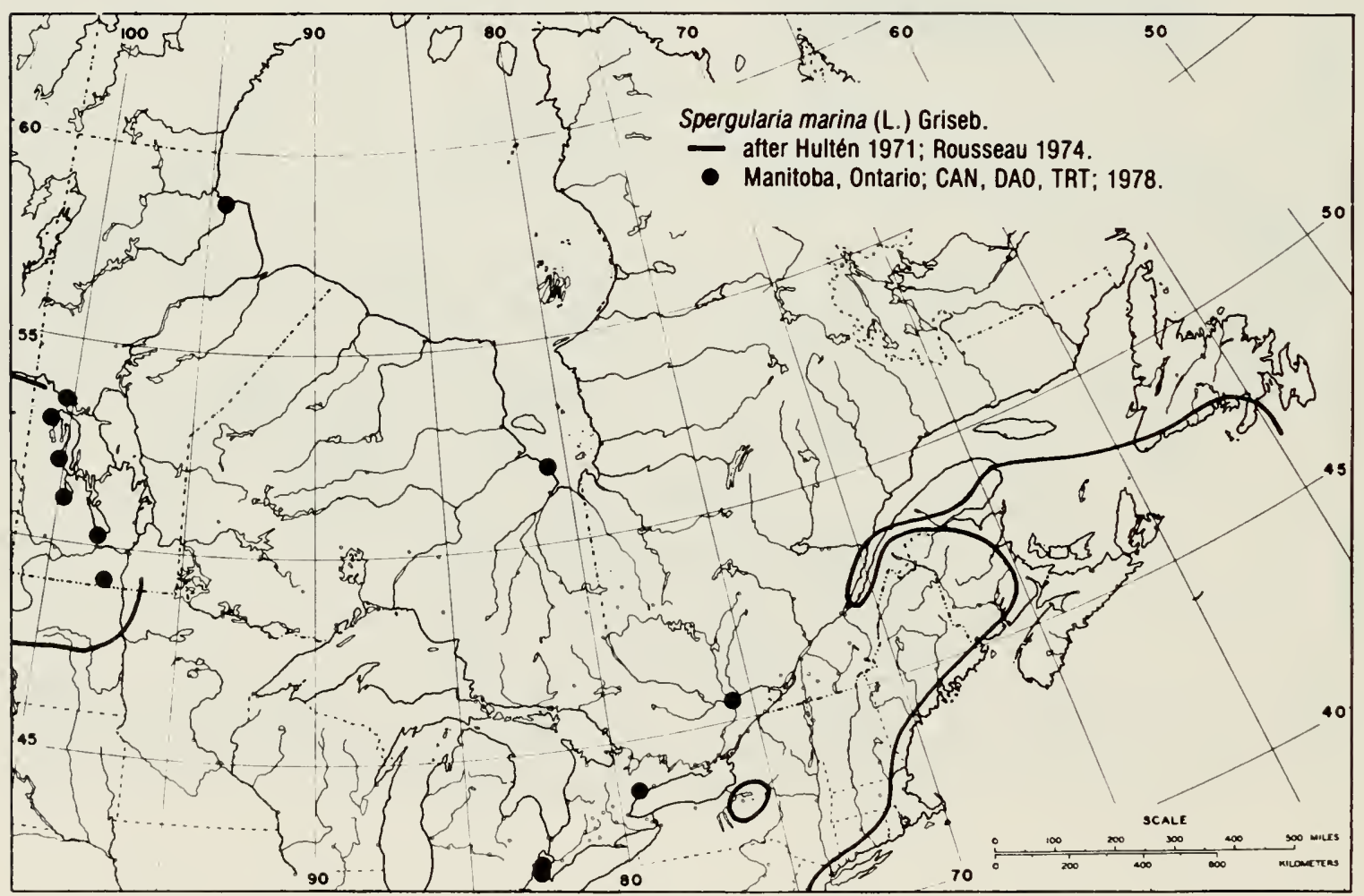

Fig. 58 Spergularia marina. Northeastern North American distribution. 


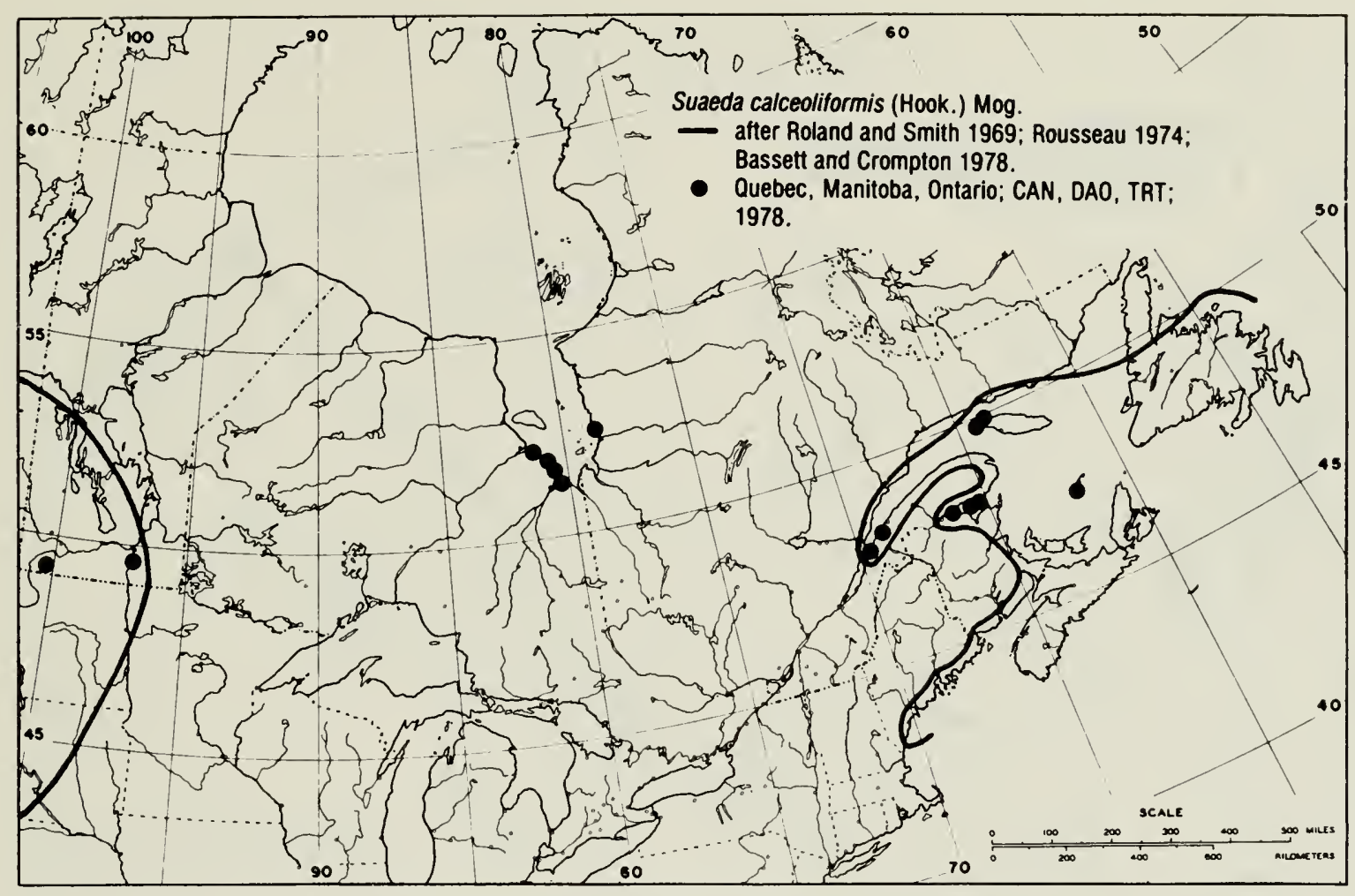

Fig. 59 Suaeda calceoliformis. Northeastern North American distribution.

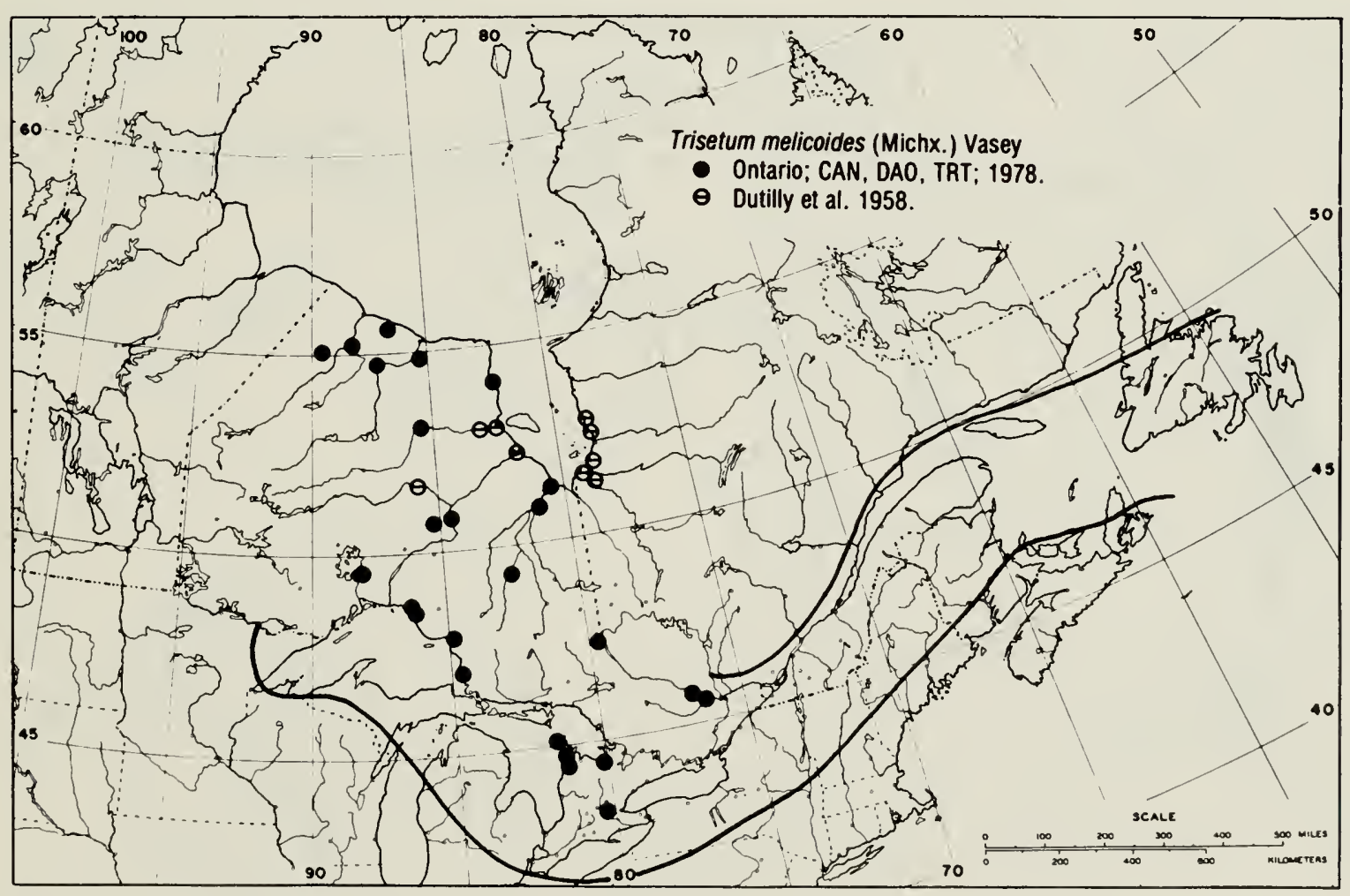

Fig. 60 Trisetum melicoides. North American distribution. 


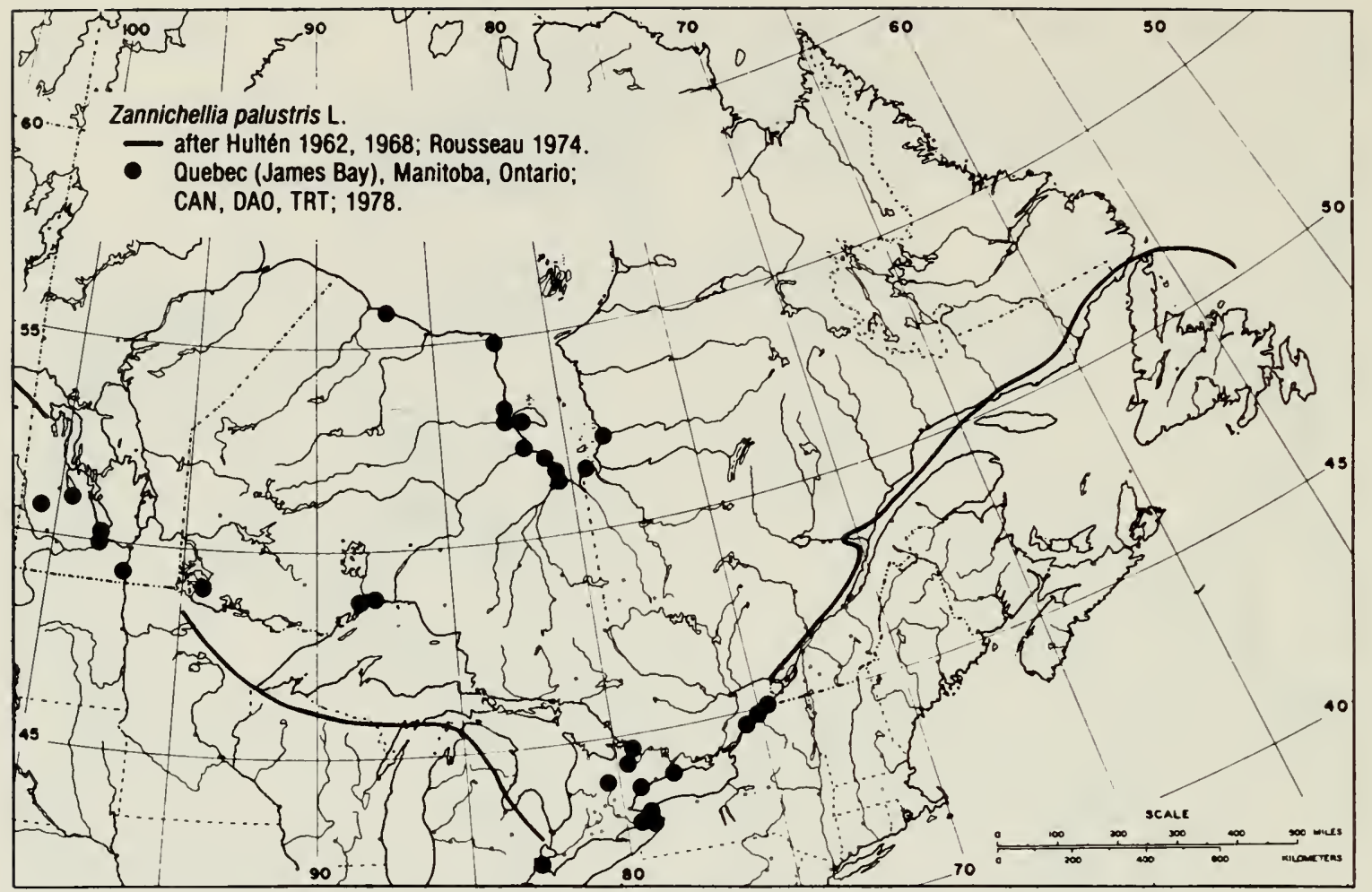

Fig. 61 Zannichellia palustris. Northeastern North American distribution.

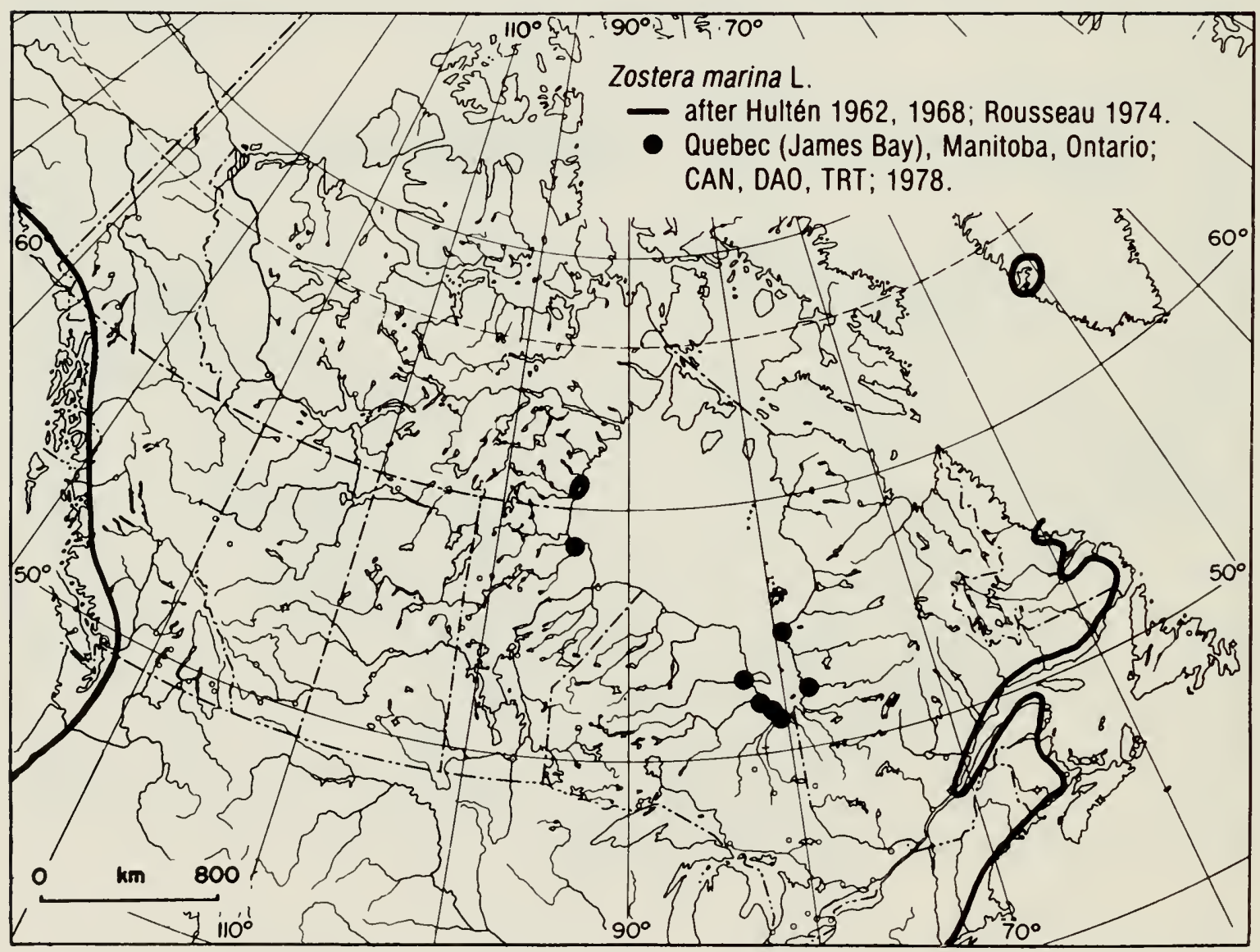

Fig. 62 Zostera marina. North American distribution. 



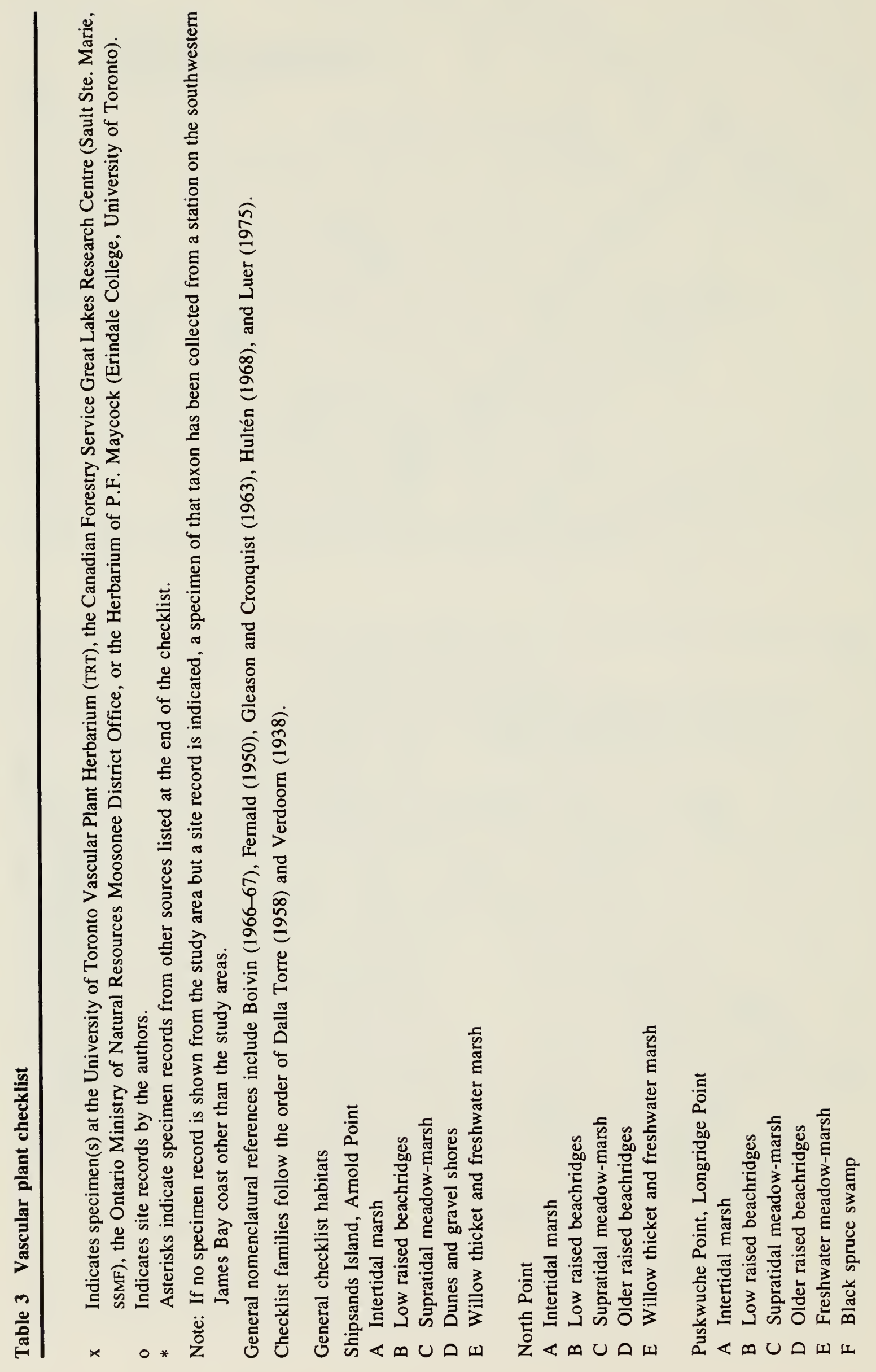




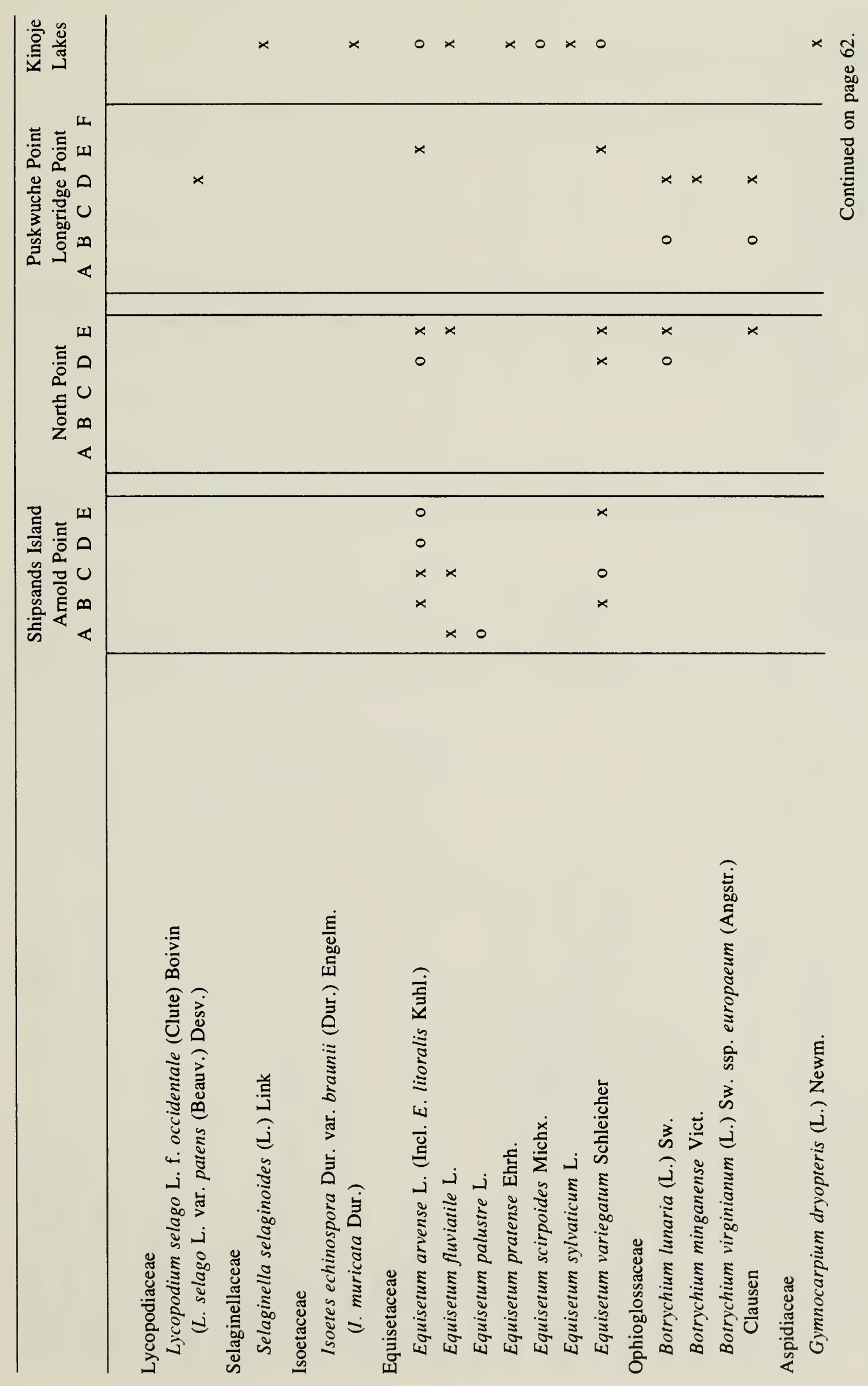




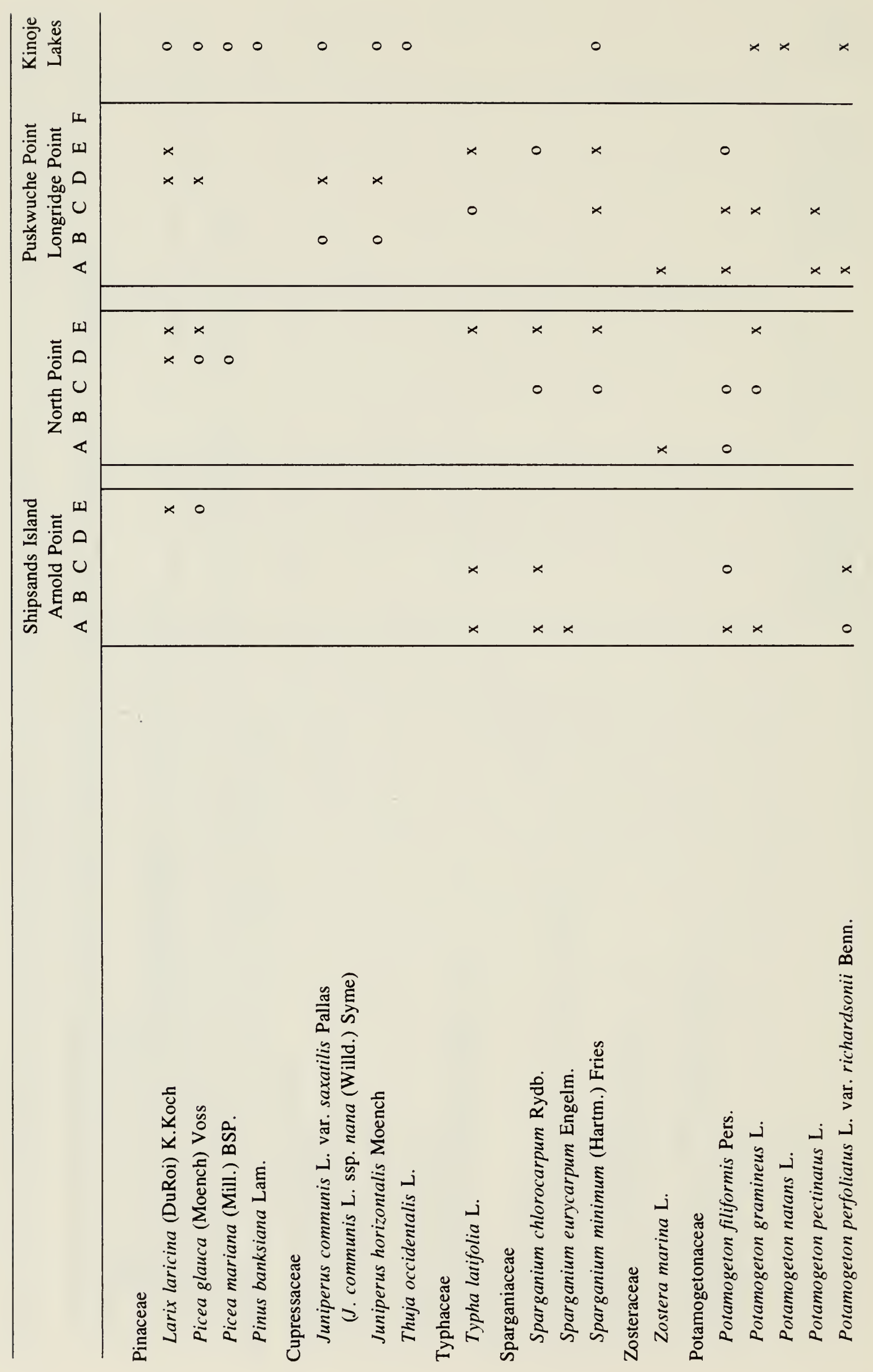



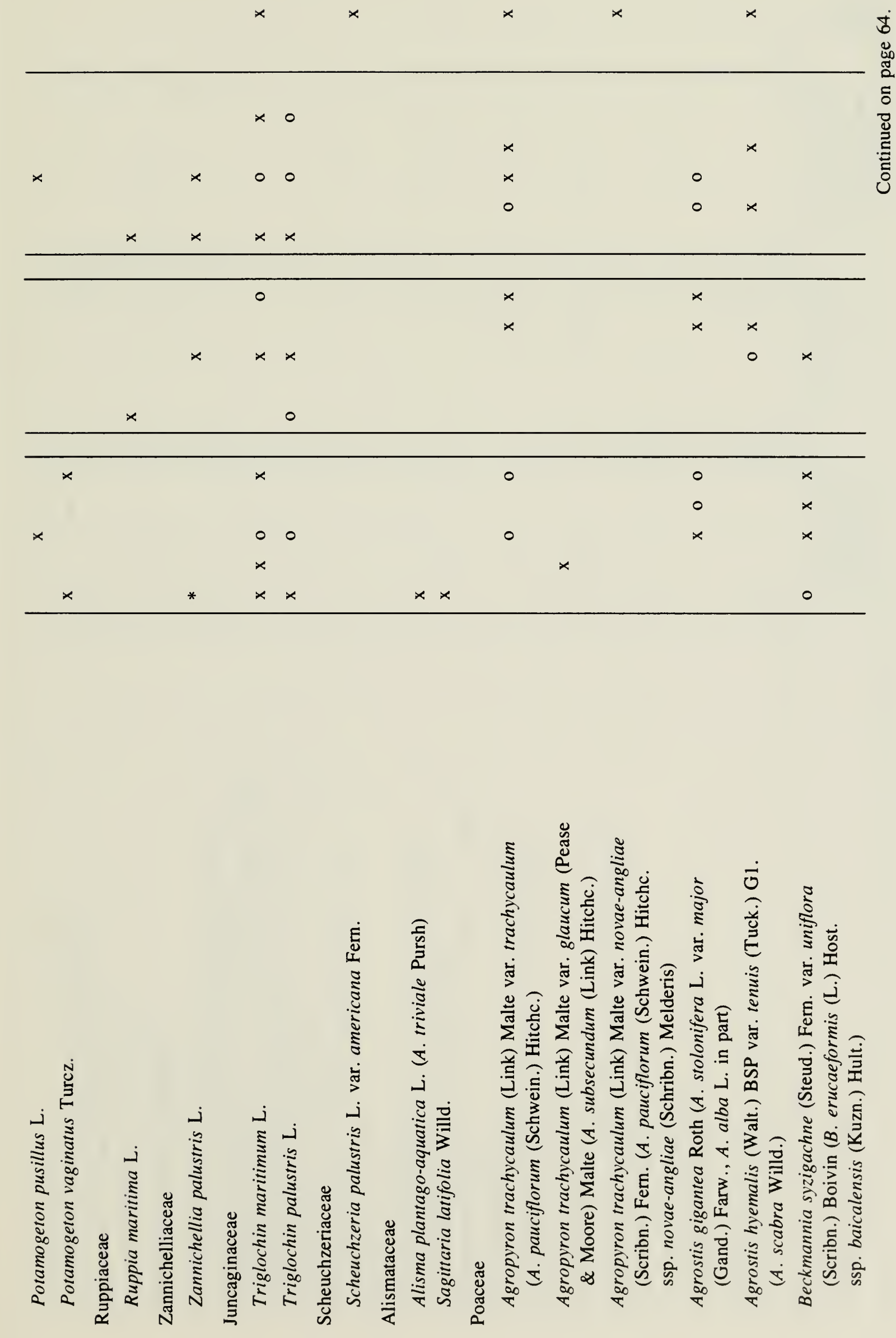


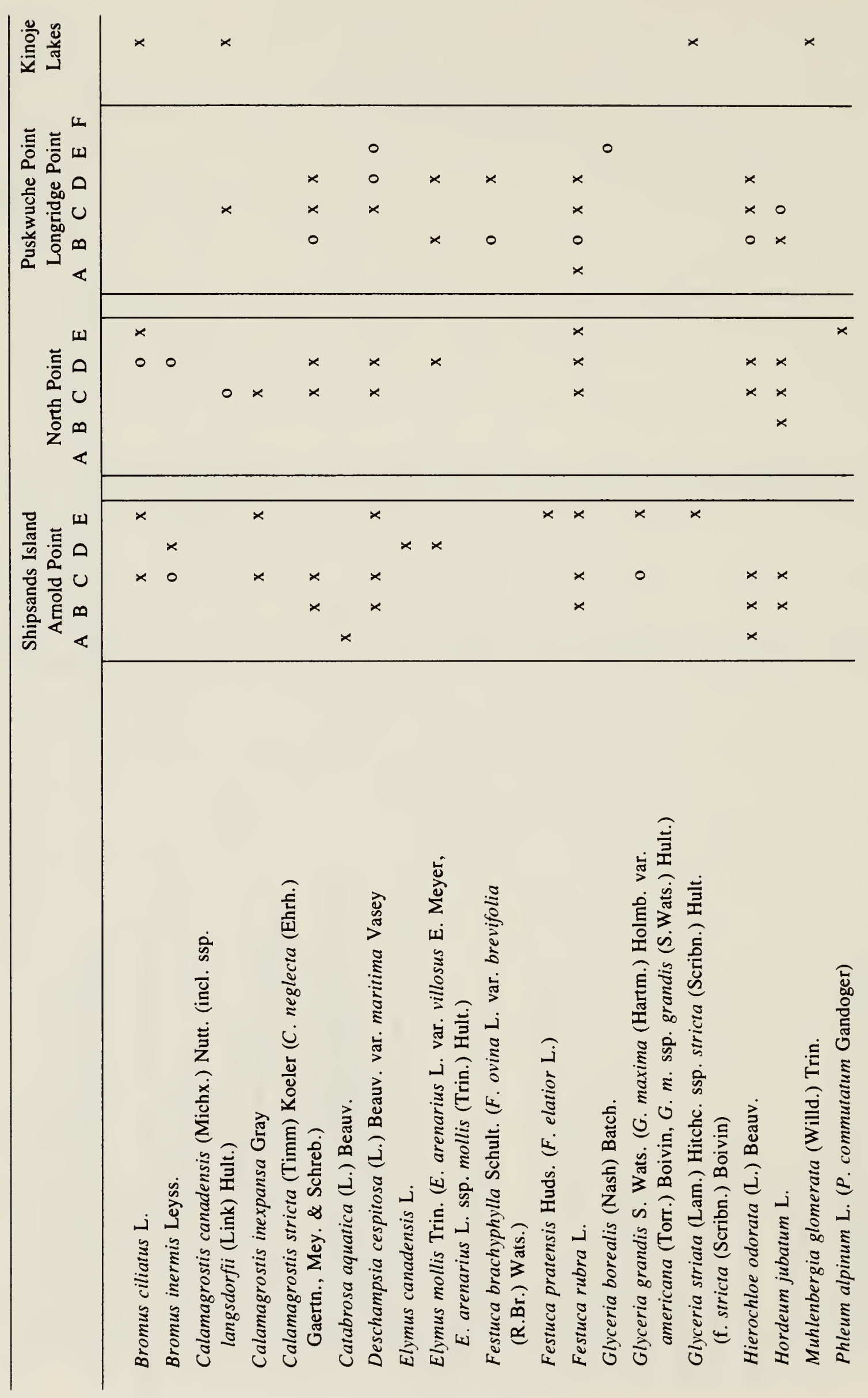



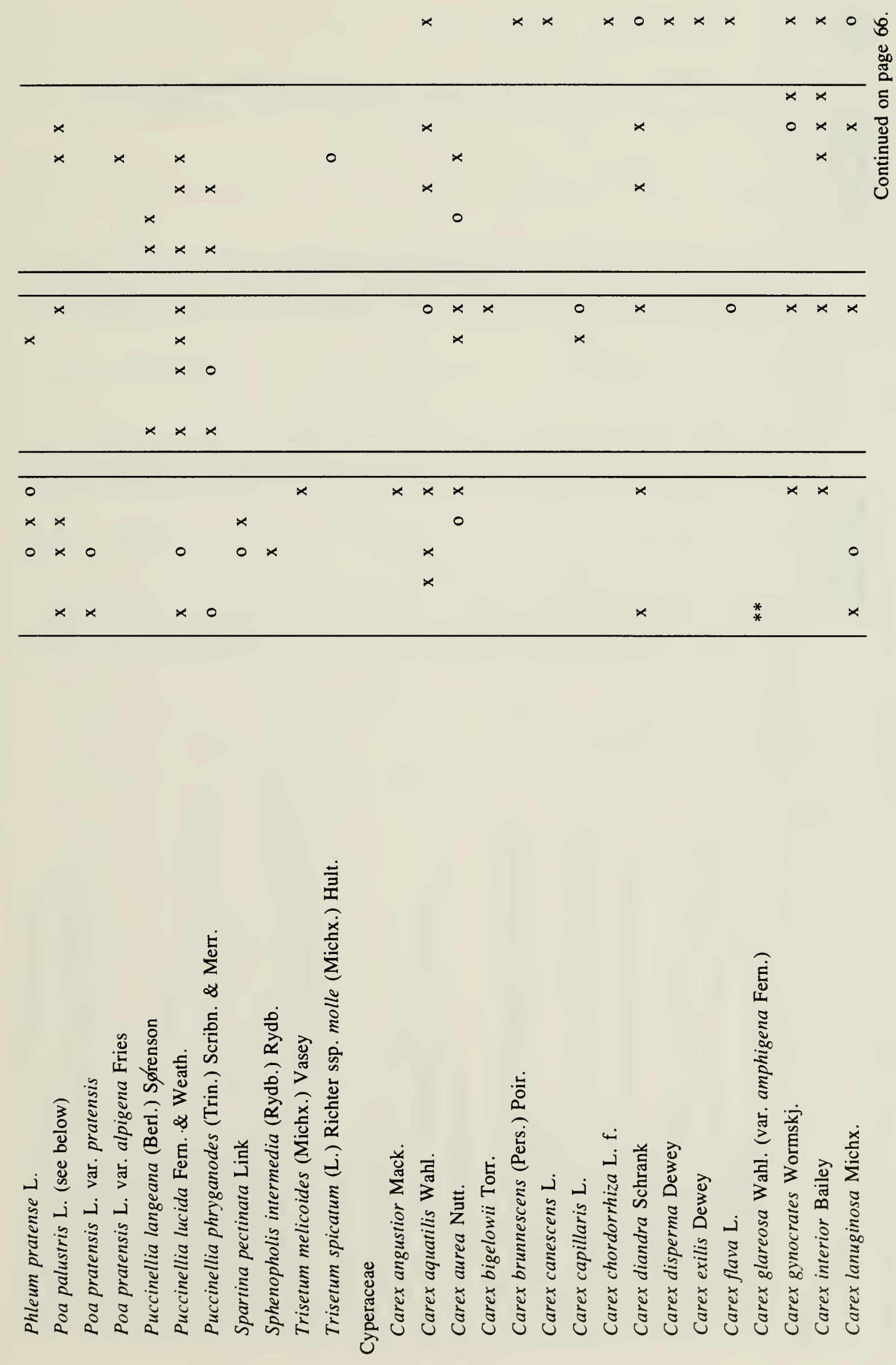


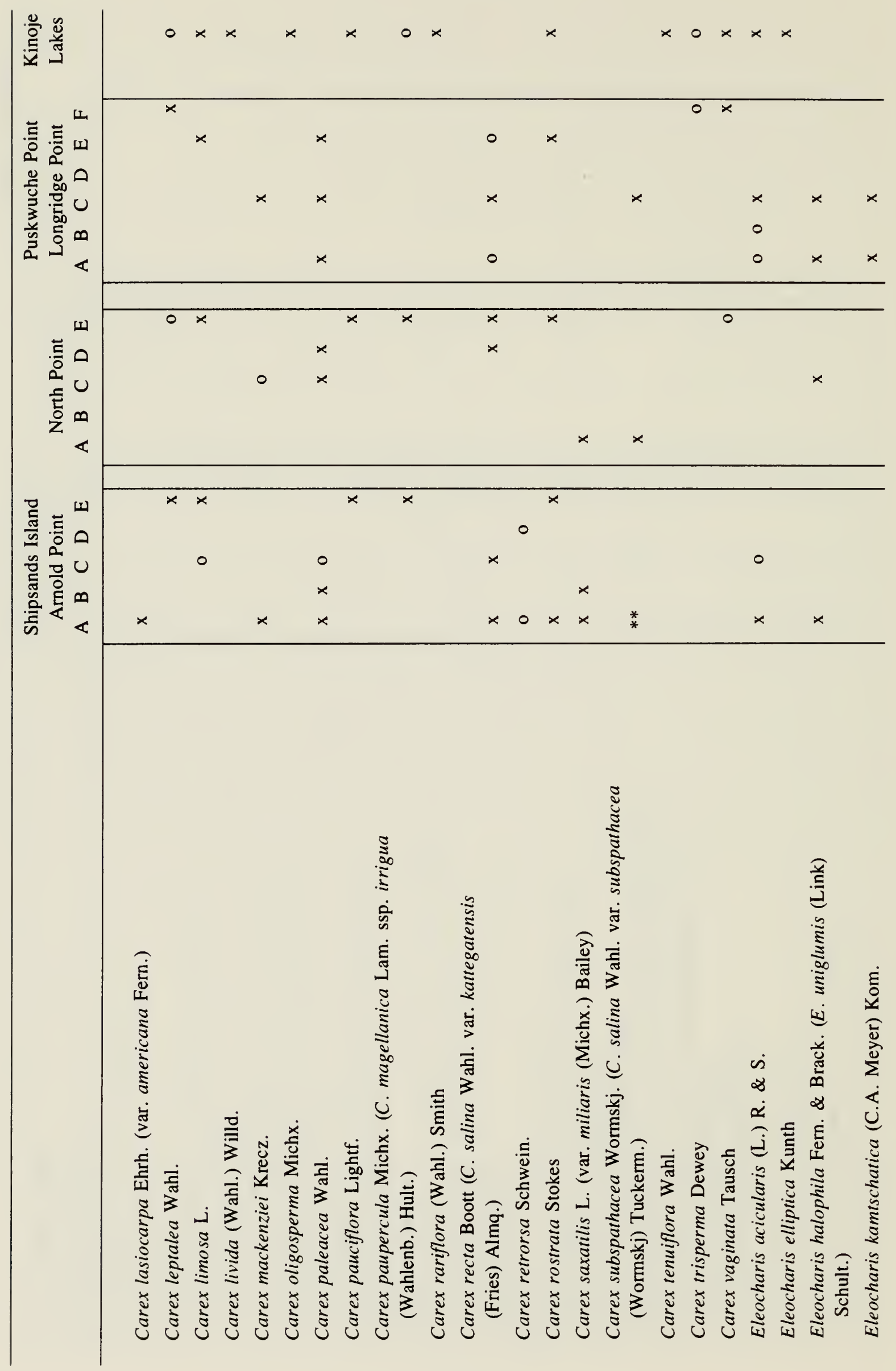



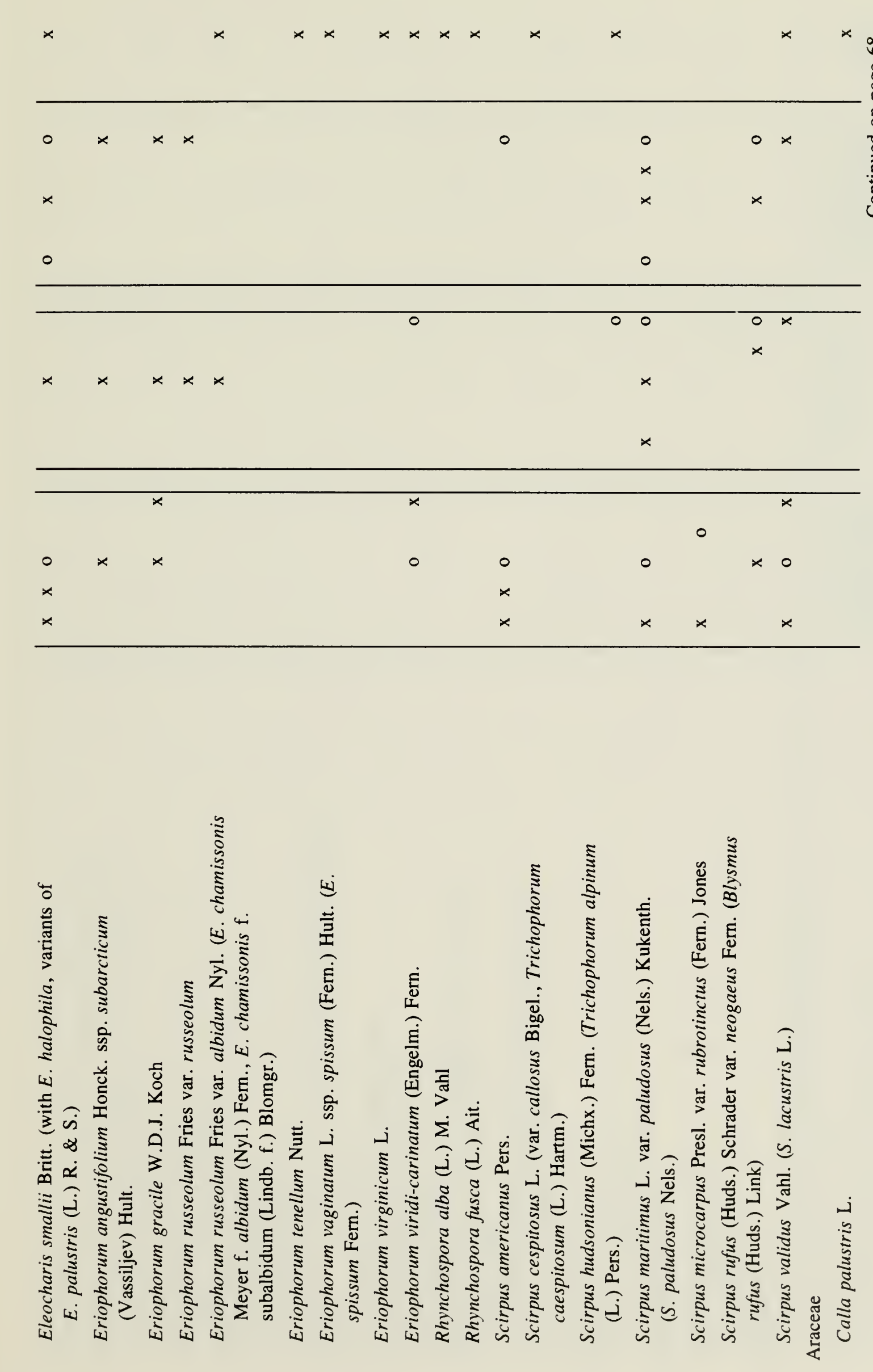


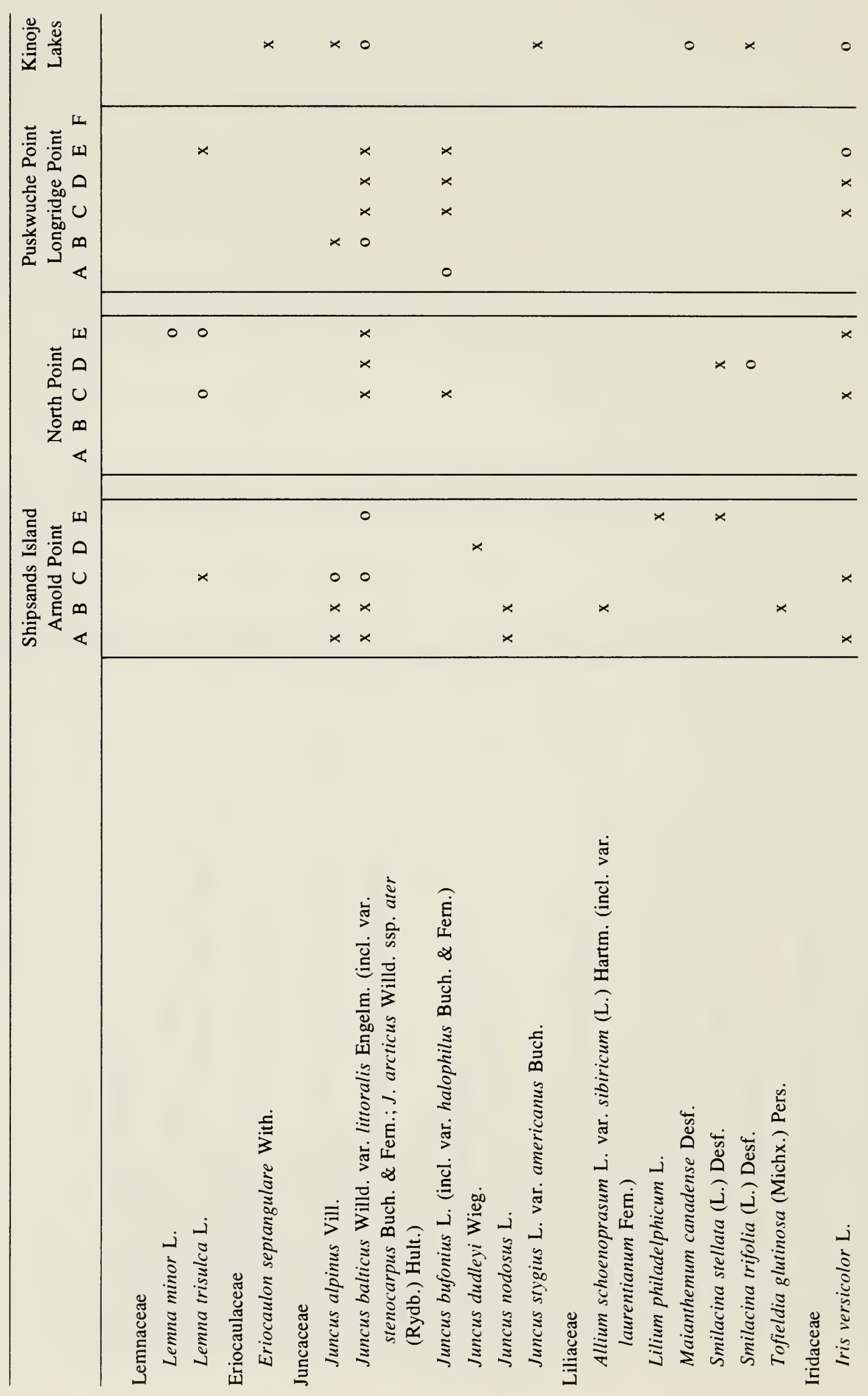



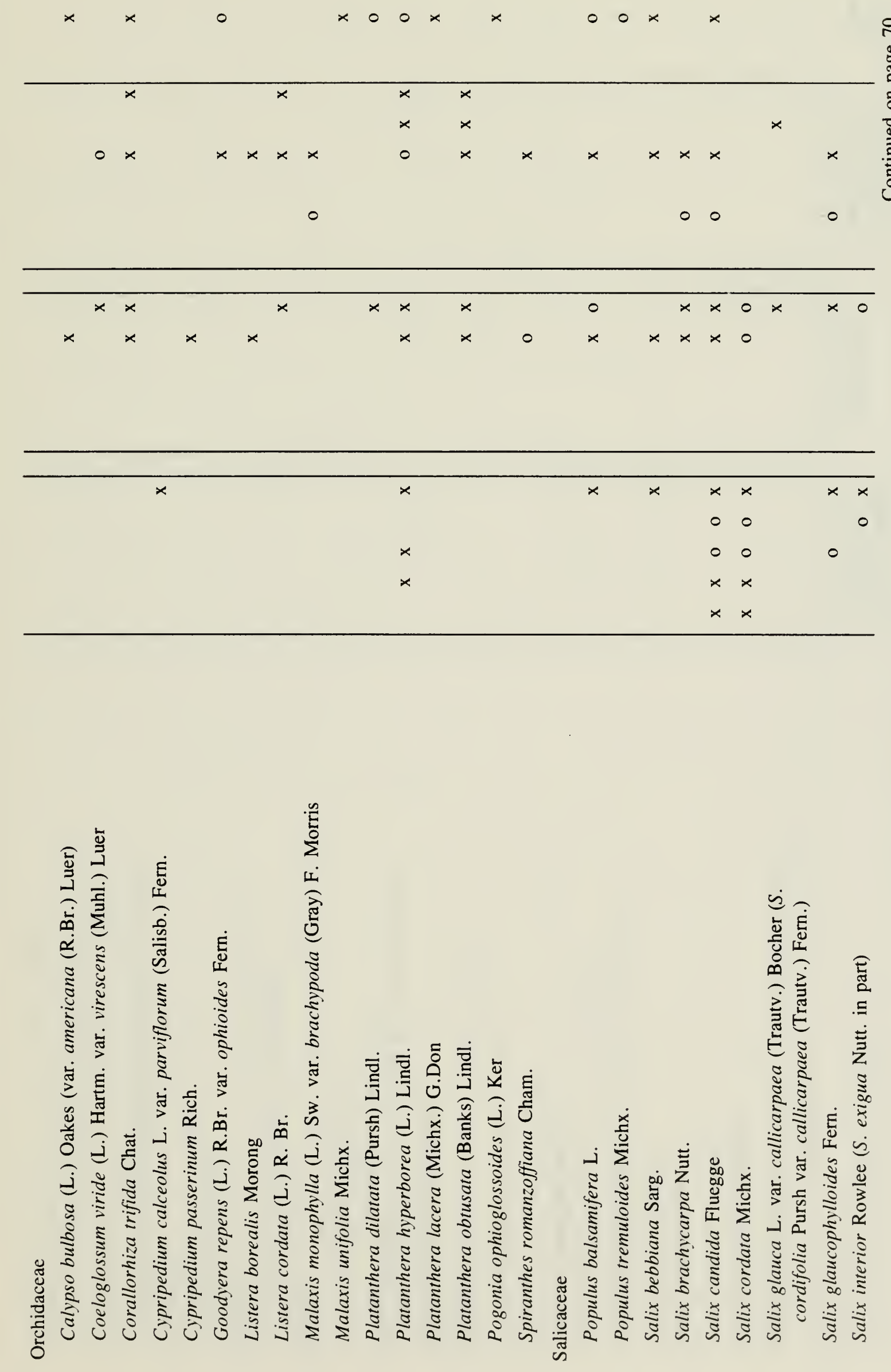


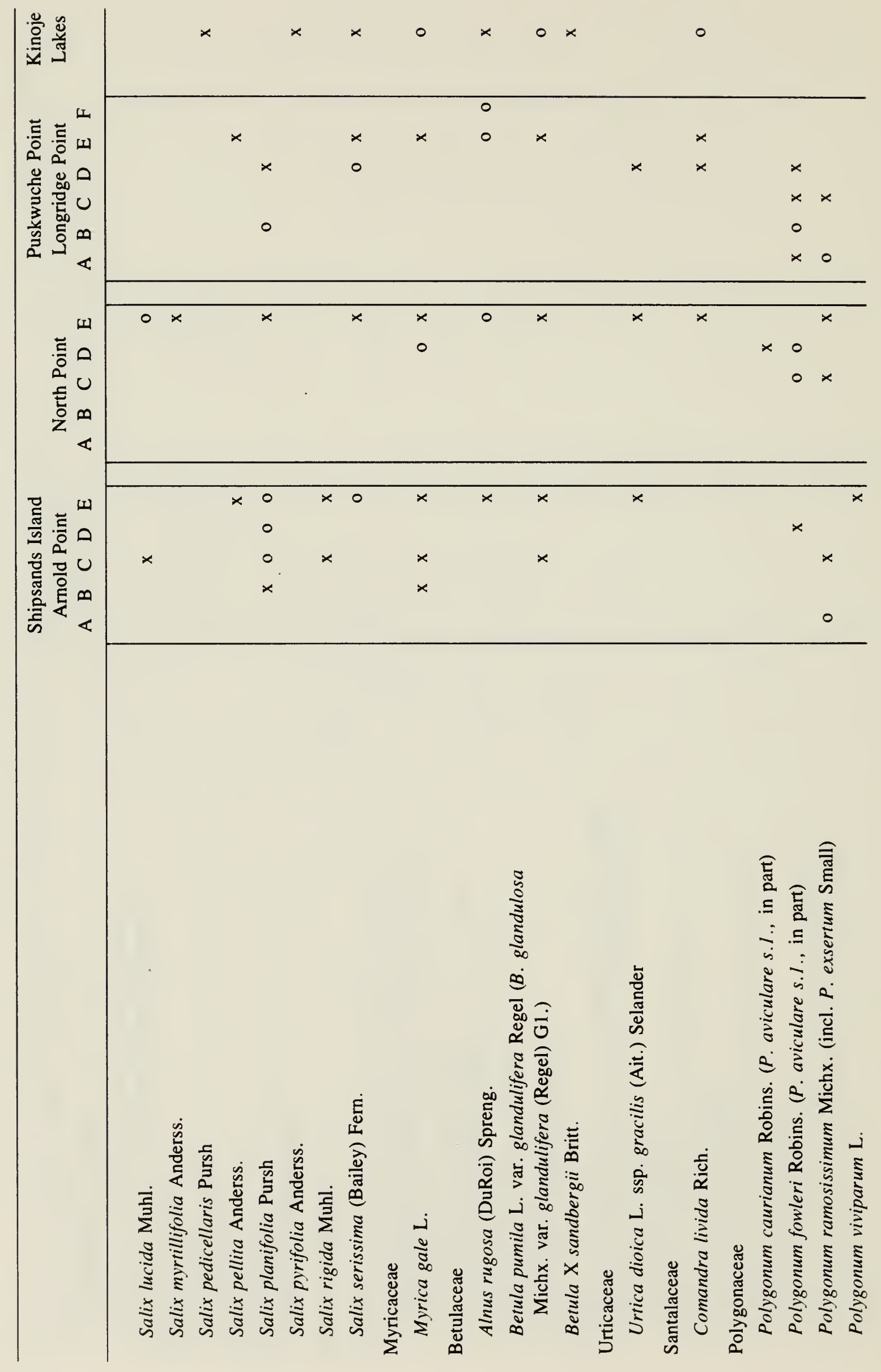



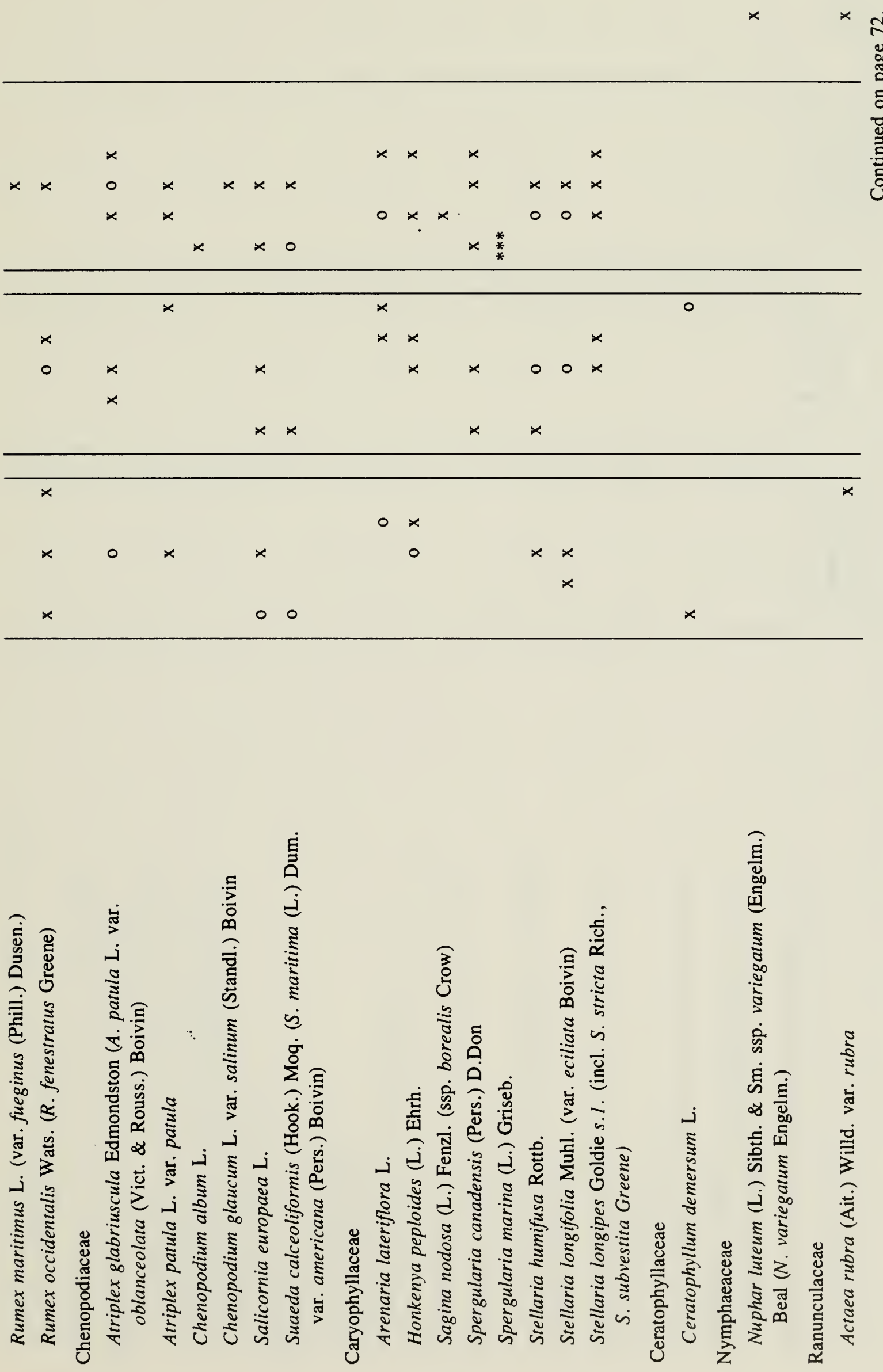


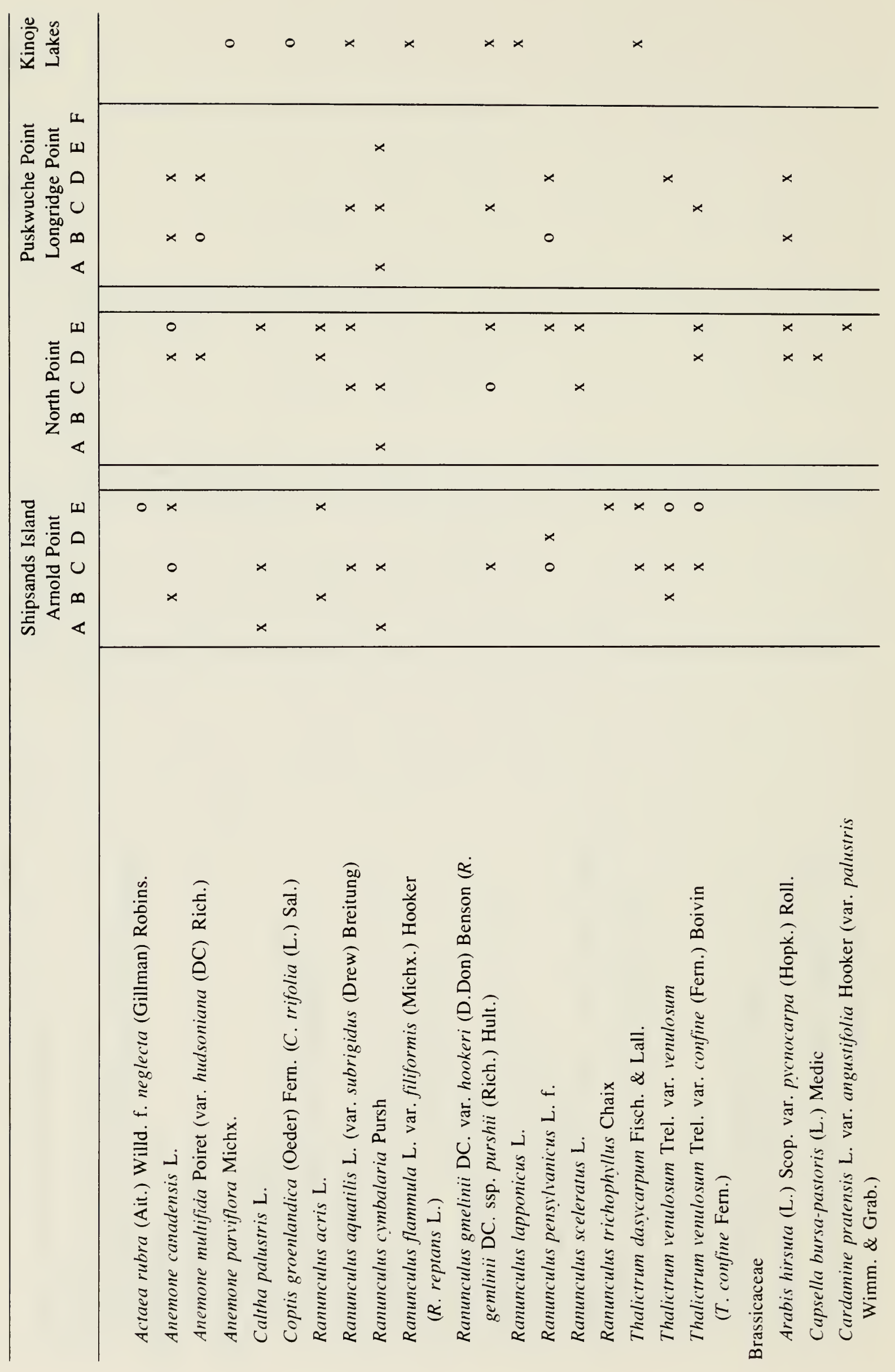



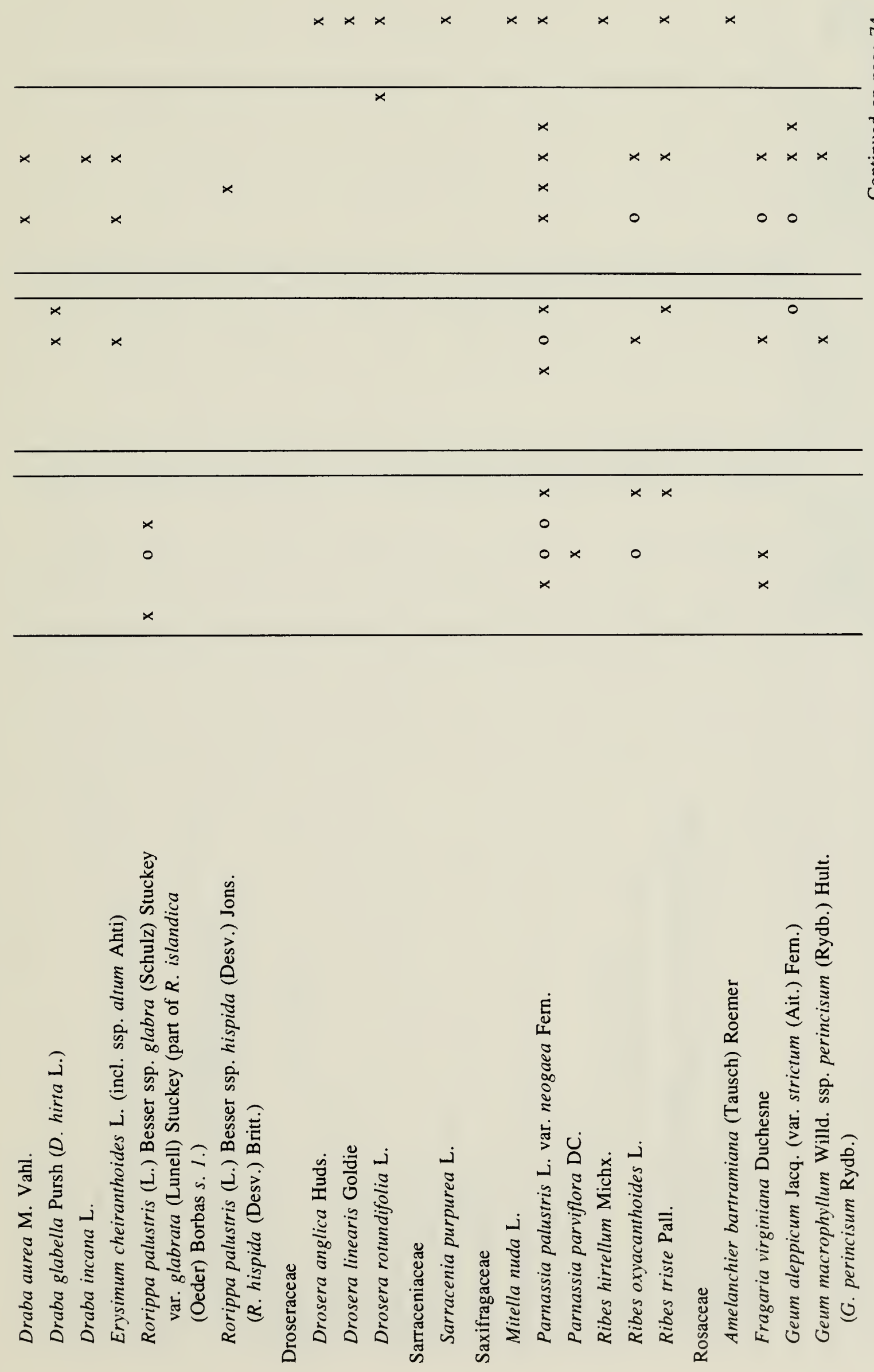


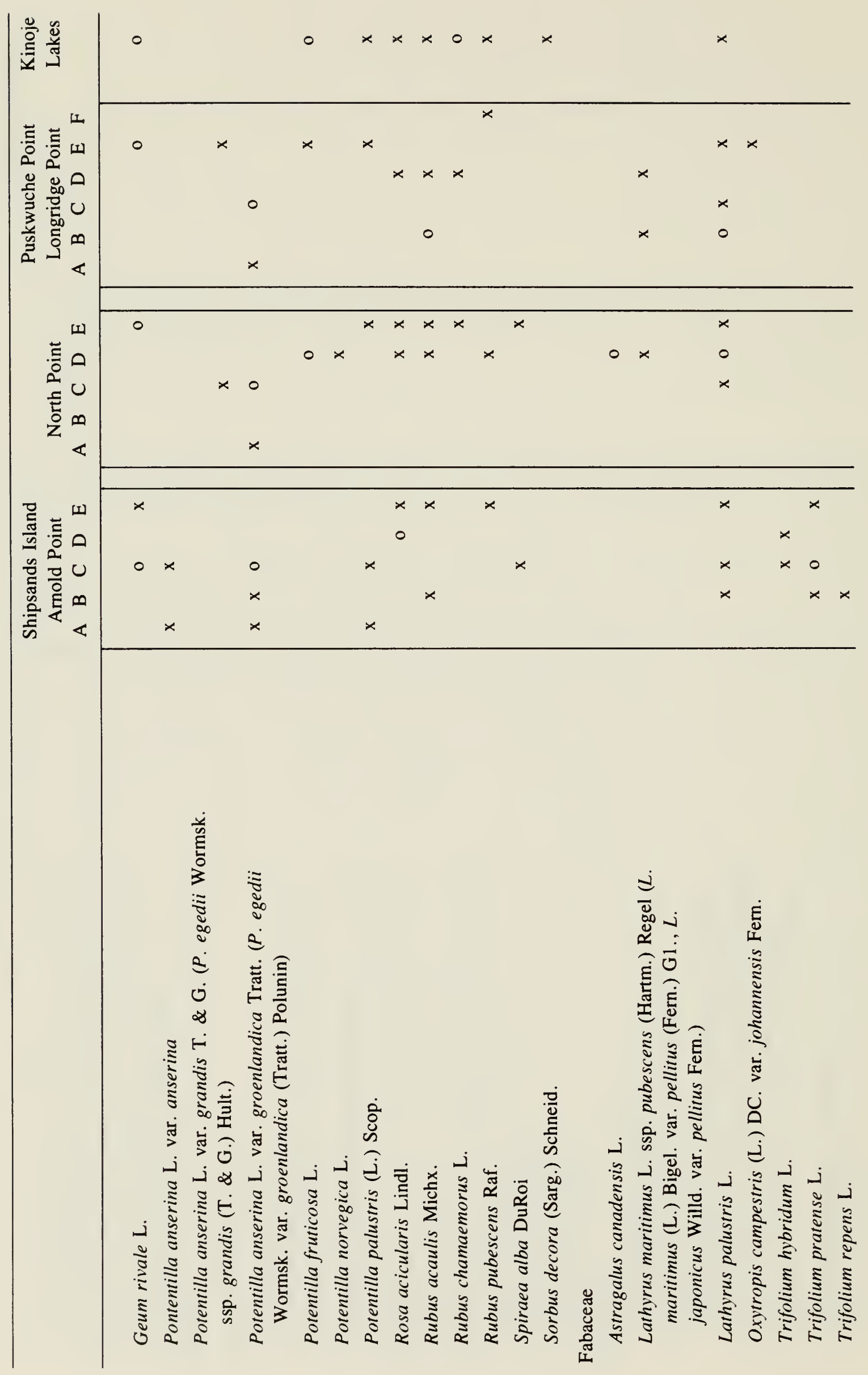



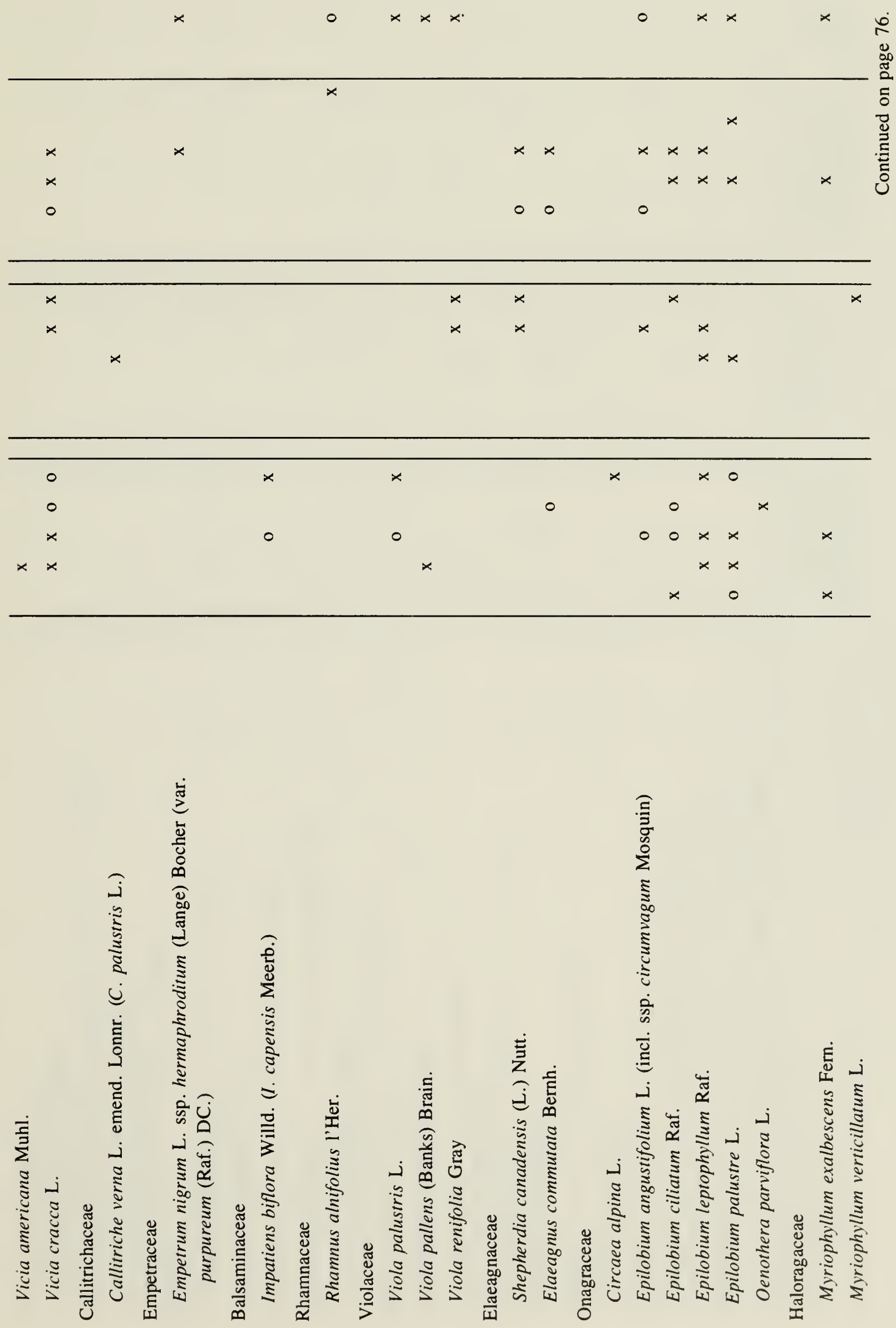


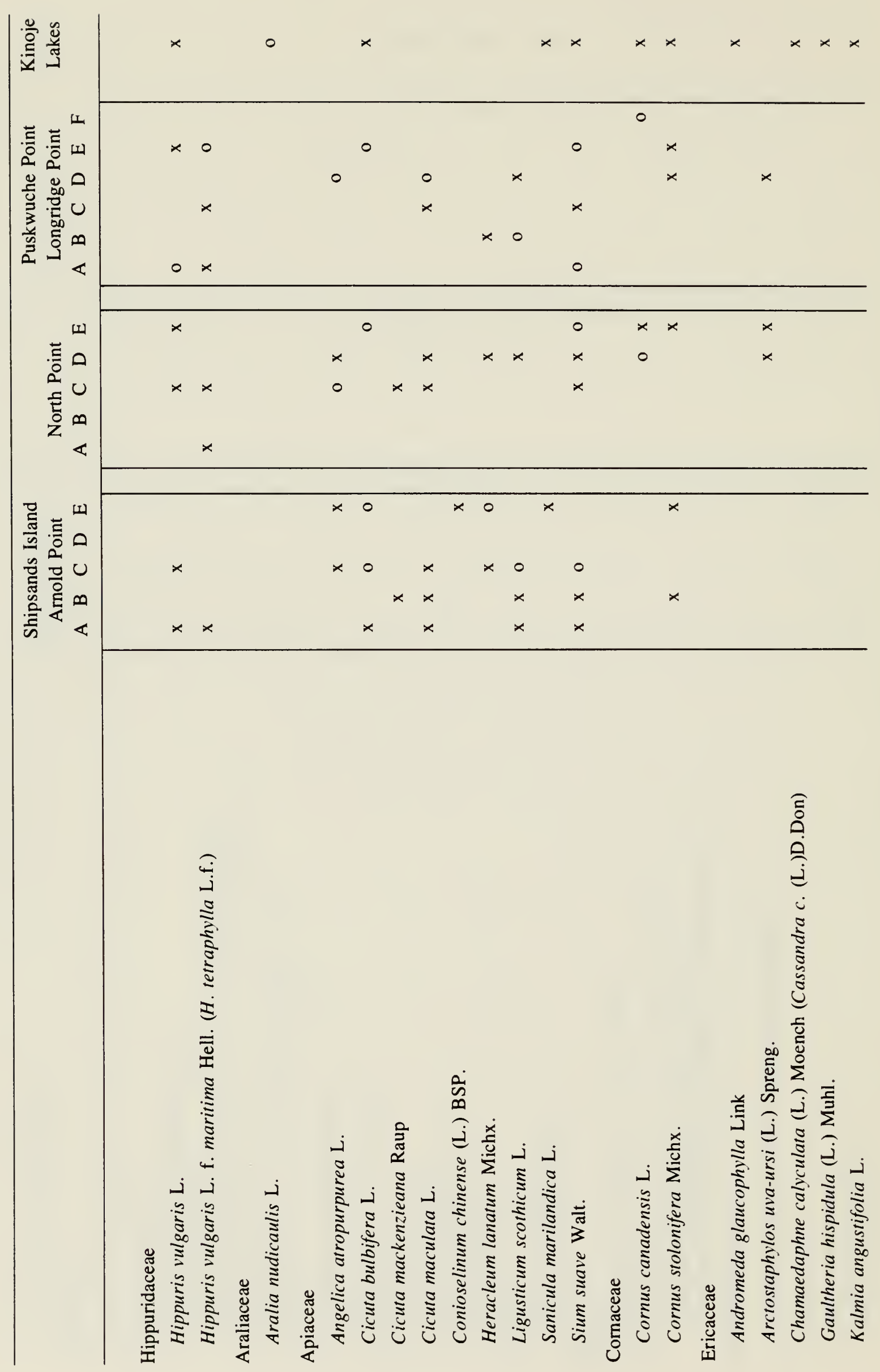



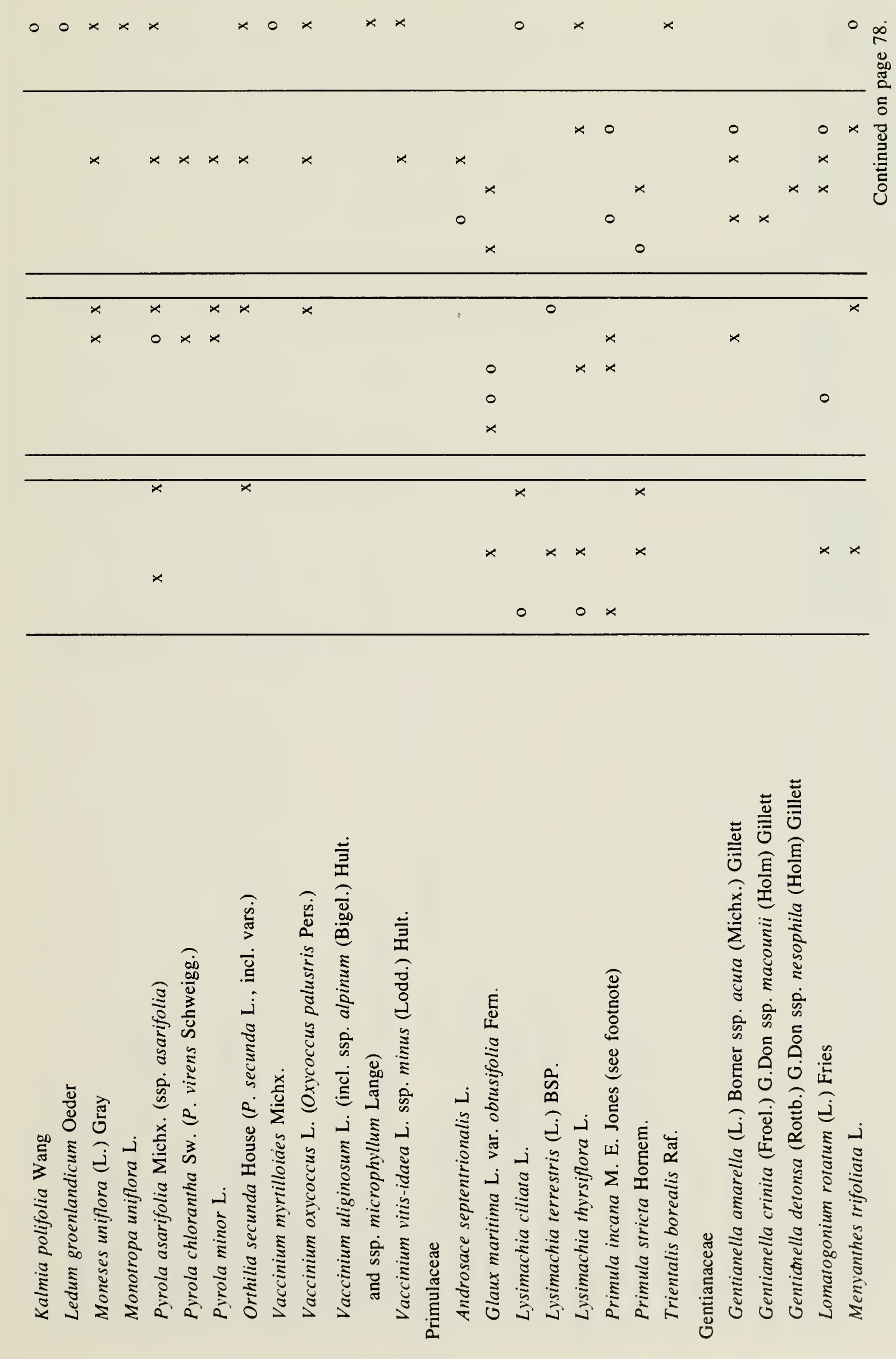


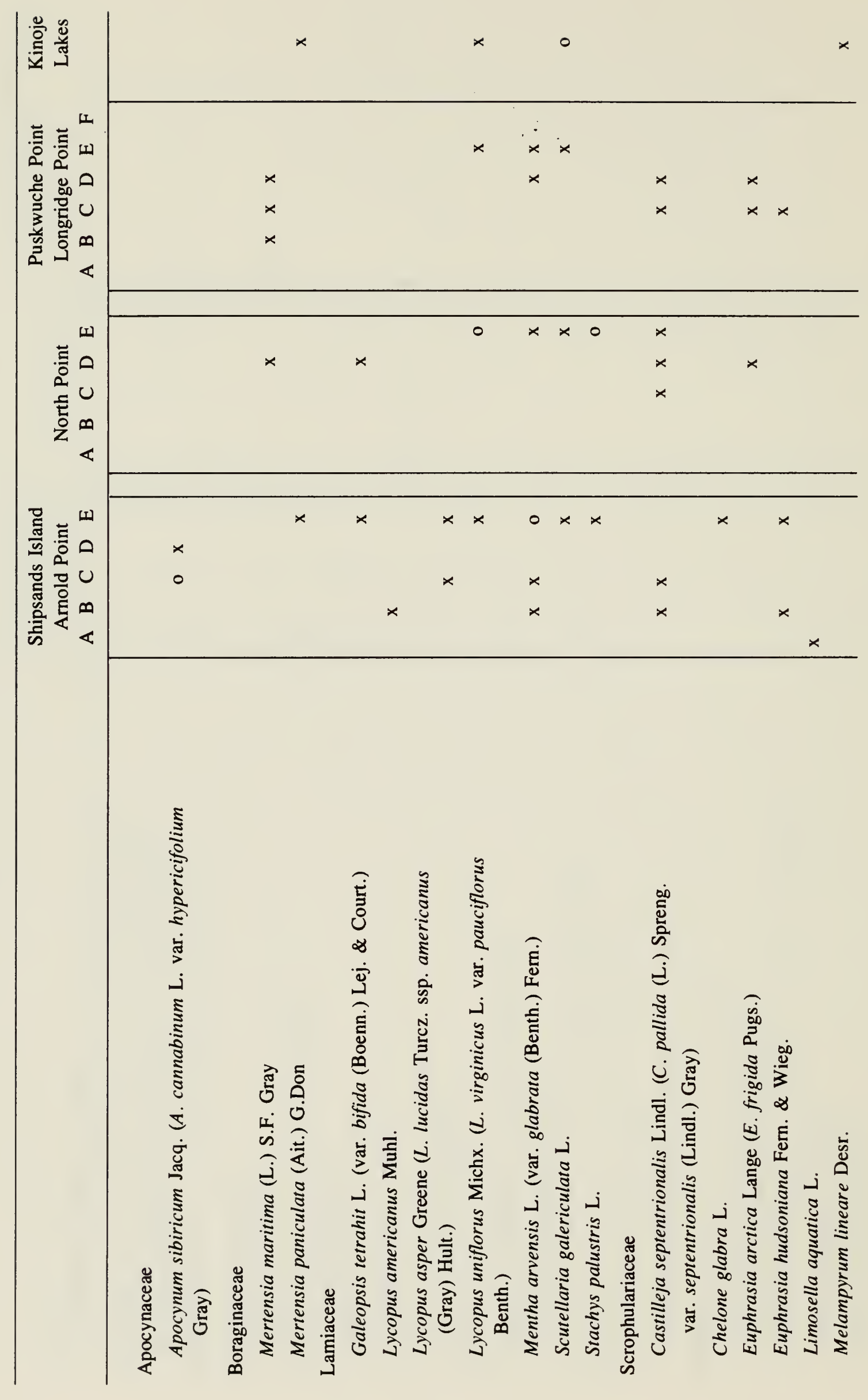



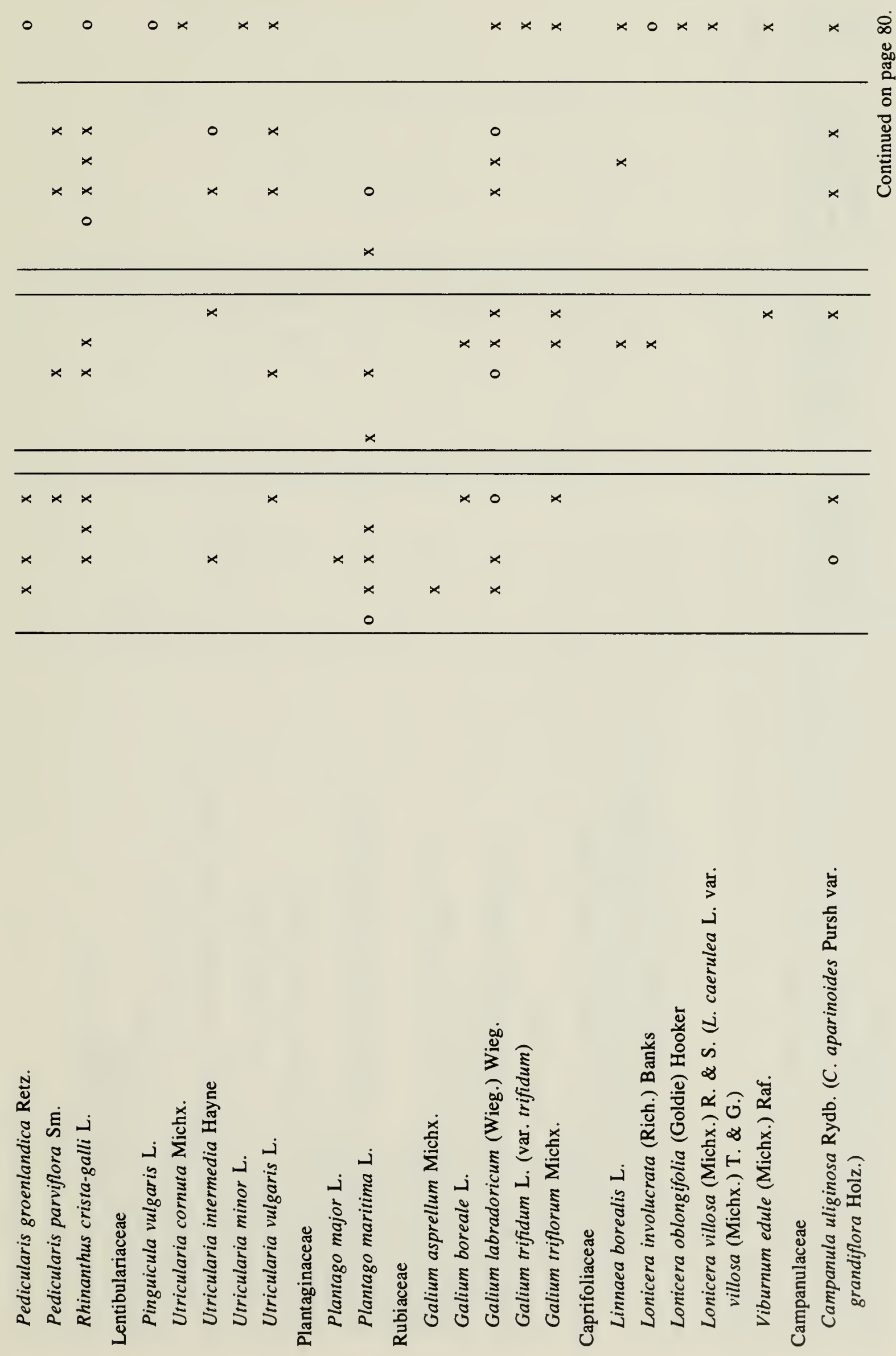


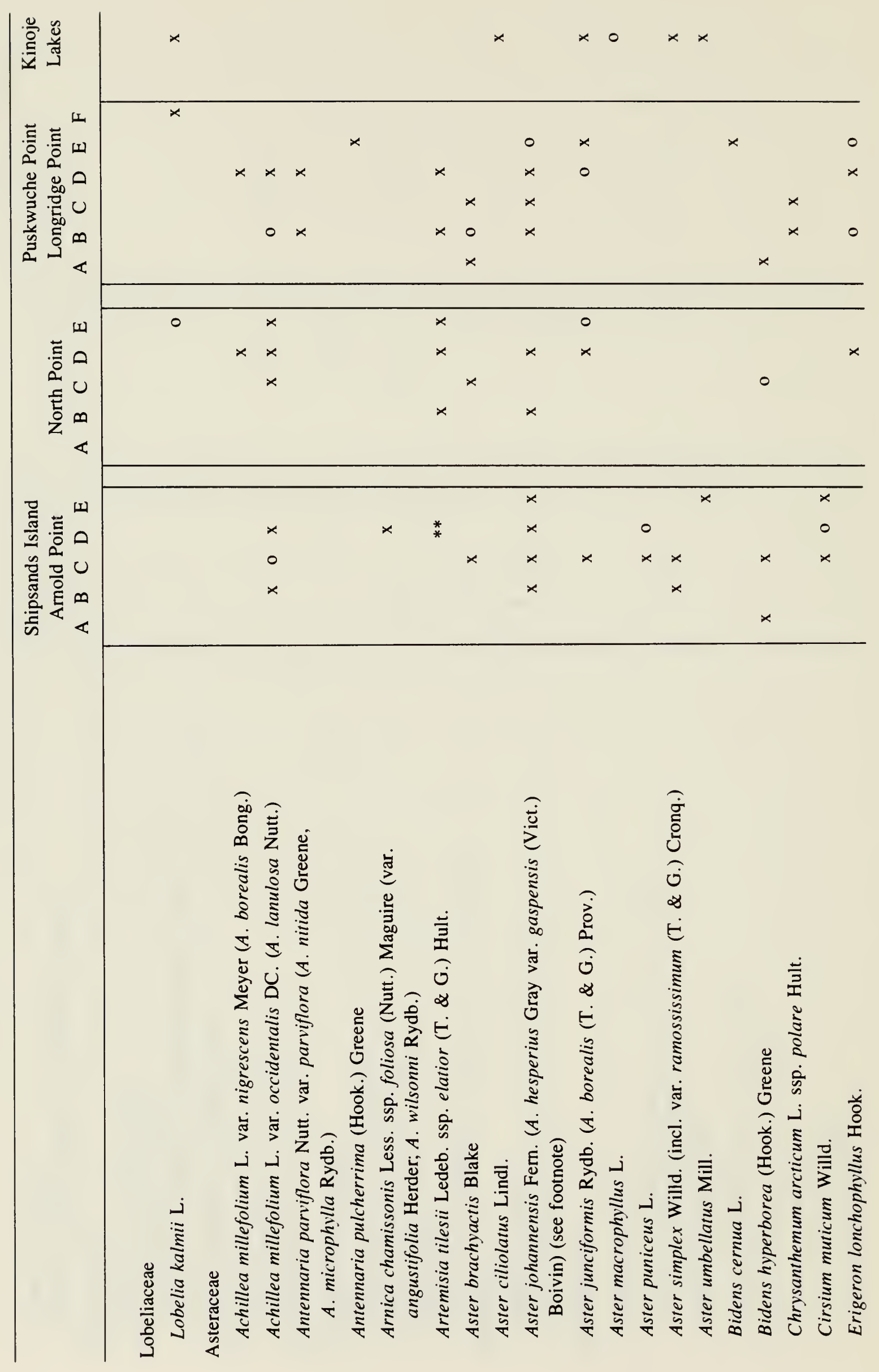




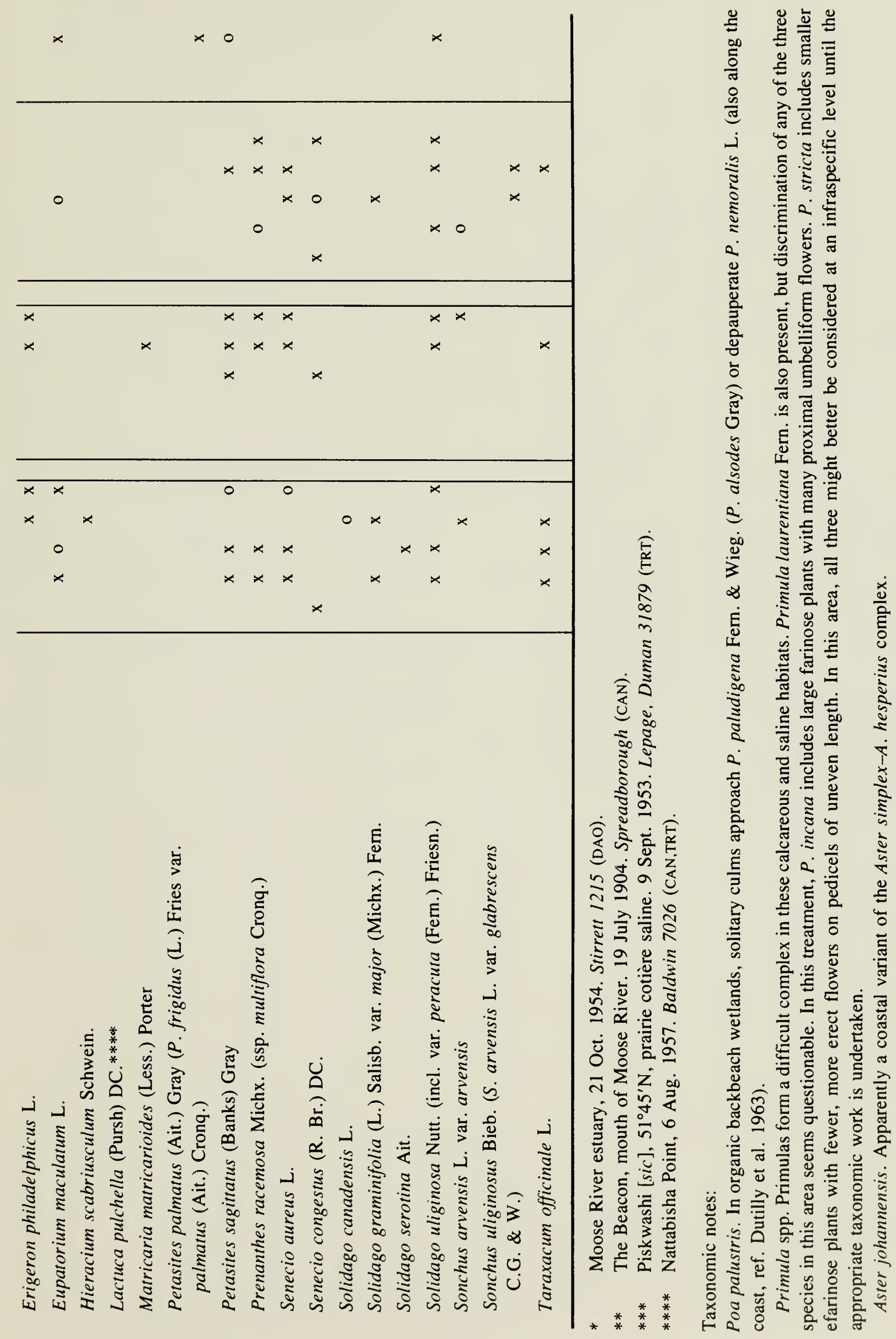






ISBN 0-88854-257-7 ISSN 0384-8159 